\title{
Radiological Bioconcentration Factors for Aquatic Terrestrial and Wetland Ecosystems at the Savannah River Site
}

by

G. P. Friday

Westinghouse Savannah River Company

Savannah River Site

Aiken, South Carolina 29808

RECEIVED

JAN 151998

OSTI

\section{MASTER}

This paper was prepared in connection with work done under the above contract number with the U.S.

Department of Energy. By acceptance of this paper, the publisher and/or recipient acknowledges the U.S. Government's right to retain a nonexclusive, royalty-free license in and to any copyright covering this paper, along with the right to reproduce and to authorize others to reproduce all or part of the copyrighted paper. 


\section{DISCLAIMER}

This report was prepared as an account of work sponsored by an agency of the United States Government. Neither the United States Government nor any agency thereof, nor any of their employees, makes any warranty, express or implied, or assumes any legal liability or responsibility for the accuracy, completeness, or usefulness of any information, apparatus, product, or process disclosed, or represents that its use would not infringe privately owned rights. Reference herein to any specific commercial product, process, or service by trade name, trademark, manufacturer, or otherwise does not necessarily constitute or imply its endorsement, recommendation, or favoring by the United States Government or any agency thereof. The views and opinions of authors expressed herein do not necessarily state or reflect those of the United States Government or any agency thereof.

This report has been reproduced directly from the best available copy.

Available to DOE and DOE contractors from the Office of Scientific and Technical Information, P.O. Box 62, Oak Ridge, TN 37831; prices available from (615) 576-8401.

Available to the public from the National Technical Information Service, U.S. Department of Commerce; 5285 Port Royal Road, Springfield, VA 22161. 


\section{DISCLAIMER}

Portions of this document may be illegible electronic image products. Images are produced from the best available original document. 


\section{Radiological Bioconcentration Factors for Aquatic, Terrestrial, and Wetland Ecosystems at the Savannah River $\operatorname{Site}(\mathbf{U})$}

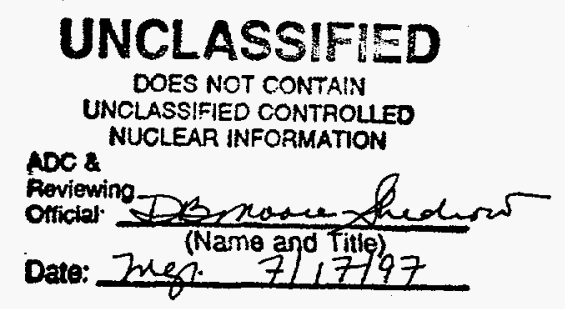

Westinghouse Savannah River Company

Savannah River Site

Aiken, SC 29808

Prepared for the U.S. Department of Energy under contract no. DE-AC09-89SR18035 


\section{Radiological Bioconcentration Factors for Aquatic, Terres- trial, and Wetland Ecosystems at the Savannah River Site (U)}

G.P. Friday, C.L. Cummins, and A.L. Schwartzman

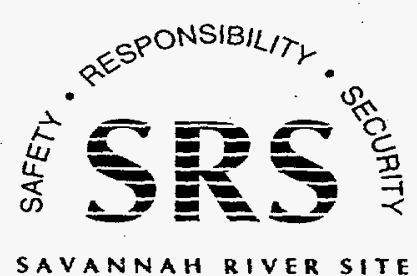

Prepared for the U.S. Department of Energy under contract no. DE-AC09-89SR 18035 


\section{TABLE OF CONTENTS}

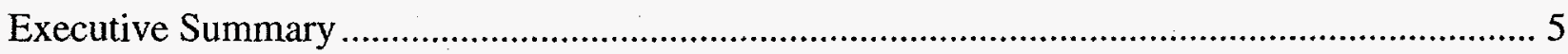

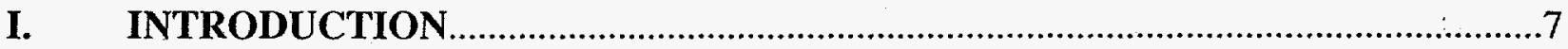

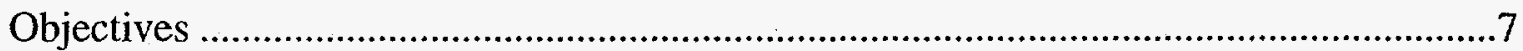

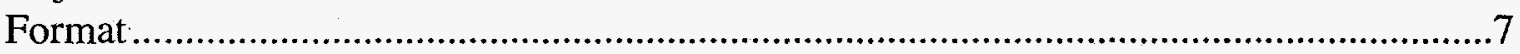

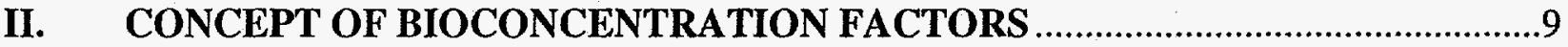

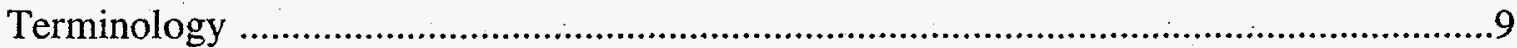

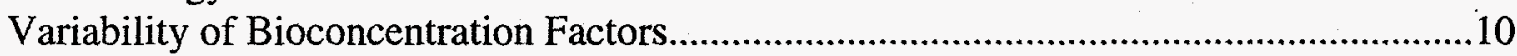

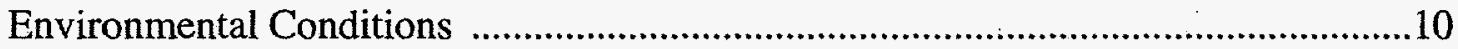

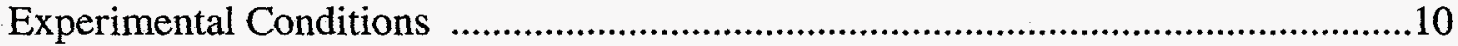

Bioavailability of Radionuclides to Biota from Water and Sediment ............................11

Bioavailability of Radionuclides to Biota from Soil............................................... 11

III. CESIUM

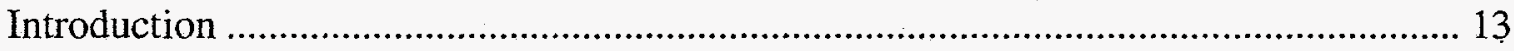

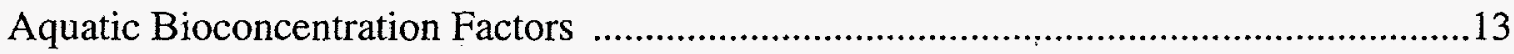

Terrestrial and Wetland Bioconcentration Factors .................................................... 18

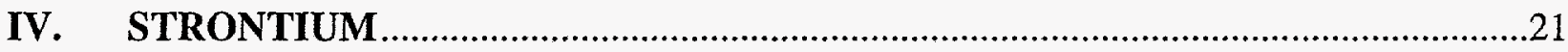

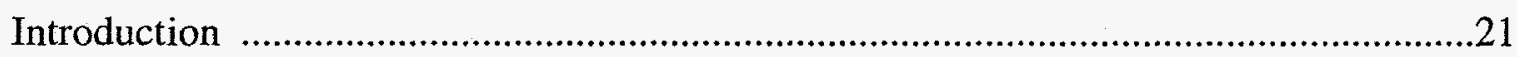

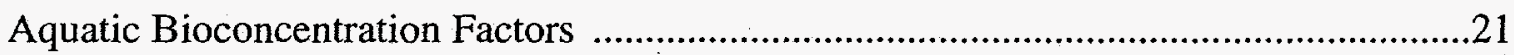

Terrestrial and Wetland Bioconcentration Factors .................................................... 23

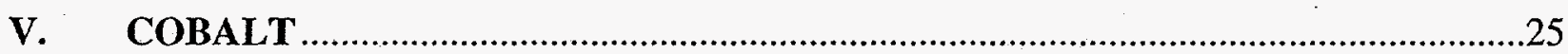

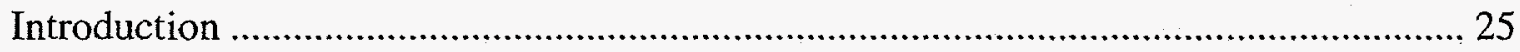

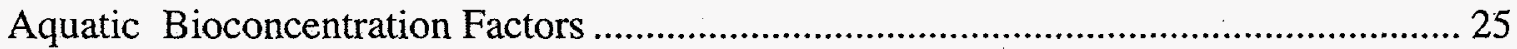

Terrestrial and Wetland Bioconcentration Factors ..............................................26

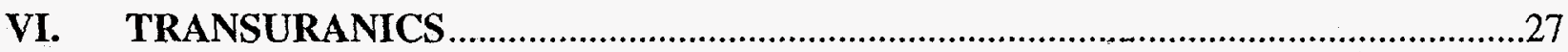

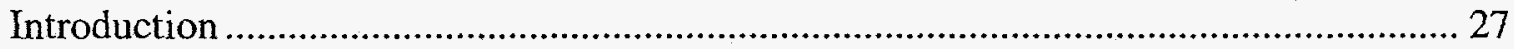

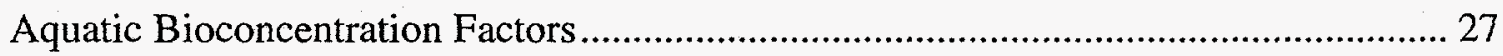

Terrestrial and Wetland Bioconcentration Factors................................................... 30

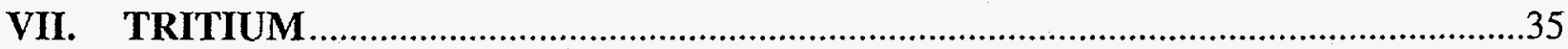

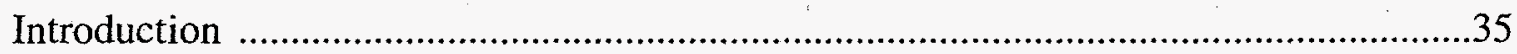

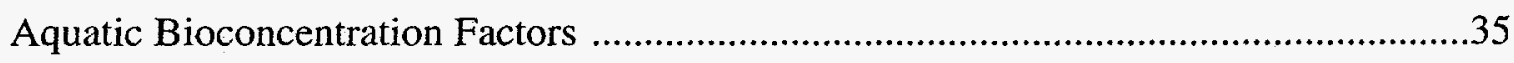

Terrestrial and Wetland Bioconcentration Factors..............................................35

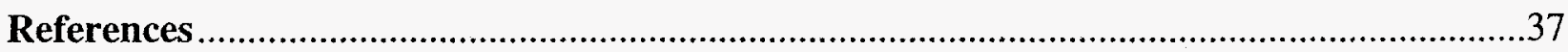


APPENDIX A

AQUATIC BIOCONCENTRATION FACTORS

A-1

APPENDIX B

TERRESTRIAL AND WETLAND BIOCONCENTRATION FACTORS

APPENDIX C

MAP OF THE SAVANNAH RIVER SITE .C-1

\section{LIST OF TABLES}

3-1. Bioconcentration Factors for Cesium in Aquatic Ecosystems .15

3-2. Bioconcentration Factors for Cs-137 in Selected Biota at SRS Impoundments, 1993-1996. 17

3-3. Bioconcentration Factors for Cs-137 in Terrestrial and Wetland Ecosystems.

4-1. Bioconcentration Factors for Strontium in Aquatic Ecosystems.

4-2. Bioconcentration Factors for Strontium in Terrestrial and Wetland Ecosystems .....

5-1. Bioconcentration Factors for Cobalt in Terrestrial and Wetland Ecosystems... . .26

6-1. Bioconcentration Factors for Transuranics in Aquatic Ecosystems.

6-2. Bioconcentration Factors for Transuranics in Terrestrial and Wetland Ecosystems. 


\section{Radiological Bioconcentration Factors for Aquatic, Terrestrial, and Wetland Ecosystems at the Savannah River Site}

G. P. Friday, C. L. Cummins, and A.L. Schwartzman

\section{Executive Summary}

Since the early 1950s, the Savannah River Site (SRS) released over 50 radionuclides into the environment while producing nuclear defense materials. These releases directly exposed aquatic and terrestrial biota to ionizing radiation from surface water, soil, and sediment, and also indirectly by the ingestion of items in the food chain. As part of new missions to develop waste management strategies and identify cost-effective environmental restoration options, knowledge concerning the uptake and distribution of these radionuclides is essential.

An index for examining the relationship between biota and radioactivity is the bioconcentration factor (BCF). The bioconcentration factor is the ratio of radioactivity or concentration of a constituent in biota to levels present in the environment. Numerous investigations have been conducted at the SRS during the past forty years to examine the uptake and distribution of radionuclides in the environment. In these studies, bioconcentration factors had to be derived from the literature because site-specific data were unavailable. Because of the variability of bioconcentration factores due to expermental or environmental conditions, site-specific data provide greater accuracy and better reflect actual environmental conditions.

This report compiles and summarizes site-specific bioconcentration factors for selected radionuclides released at the Savannah River Site (SRS). An extensive literature search yielded site-specific bioconcentration factors for cesium, strontium, cobalt, plutonium, americium, curium, and tritium. Unpublished data collected at several SRS impoundments such as Par Pond and L-Lake are also included in this report. These seven radionuclides have been emphasized at SRS because of their long half-lives or because they are major contributors to radiological dose from exposure. Approximately half of the site-specific bioconcentration factors were within the ranges reported in the literature. This report also summarizes some conditions that affect radionuclide bioavailablity and bioconcentration for aquatic and terrestrial organisms. 


\section{INTRODUCTION}

The Savannah River Site (SRS) produced materials (primarily tritium and plutonium-239) used in the fabrication of nuclear weapons from 1952 to 1988 . Throughout most of this period, five reactors, two chemical separation facilities, a heavy water extraction facility, a nuclear fuel and target fabrication facility, waste management facilities, and the Savannah River Technology Center operated to fulfill the site mission. Since 1988, the primary mission of SRS has shifted to waste management and environmental restoration activities. However, the SRS continues to handle nuclear materials for government and some civilian purposes.

As a result of the site's operations, over 50 radionuclides were released to the atmosphere and to onsite streams and seepage basins (Cummins et al. 1991a). When these radionuclides were released, many became available to aquatic and terrestrial organisms for uptake and cycling through the food chain. Knowledge about the uptake and cycling of these radionuclides is now crucial in determining waste management and clean-up alternatives for the site. Fortunately, the distribution of radionuclides in the Savannah River Site environment has been studied for the past forty years.

The uptake of a radionuclide by an organism from the surrounding medium (e.g.,, soil or water) can be quantified by calculating bioconcentration factors. Once calculated, bioconcentration factors can be used for several purposes. From the knowledge of the radionuclide concentration in the surrounding medium, they can be used to predict radionuclide concentrations in whole organisms or their tissues. Bioconcentration factors can also be used to estimate bioaccumulation factors, dose assessment, and as a means to predict ecological risk to organisms in the environment.

In the past, it has been common practice to use bioconcentration factors from the literature because site-specific data were not readily available. However, because of the variability of bioconcentration factors due to environmental and/or experimental conditions, this practice may inaccurately estimate the true uptake and concentration of radionuclides. Site-specific bioconcentration factors are more accurate and should be used whenever possible.
This report is a revision of an earlier work by Cummins (1994) that presented site-specific bioconcentration factors for selected radionuclides released from the SRS. This revision expands the discussion on bioaccumulation and presents new data provided by T.G. Hinton of the Savannah River Ecology Laboratory and M.H. Paller of the Savannah River Technology Center.

In addition to the site-specific bioconcentration factors, literature values are provided for comparison purposes. This report does not attempt to interpret the data presented; its primary purpose is to compile and establish a database of site-specific bioconcentration factors that can be used in the remediation of the enviornment and to support ecological risk assessment.

\section{Objectives}

The objectives of this report are to:

1. Provide site-specific bioconcentration factors for selected radionuclides

2. Establish a database which can be updated as new information becomes available.

3. Compare SRS bioconcentration factors with published literature values

4. Summarize conditions affecting radionuclide bioavailablity and bioconcentration

\section{Format}

This report consists of seven chapters. Chapter II discusses the concept of bioconcentration factors, including the definition and variability of the bioconcentration factors and the bioavailability of radionuclides to biota from soil and water. Chapters III - VII summarize the bioconcentration factors for cesium, cobalt, strontium, transuranics (plutonium, americium, and curium), and tritium, respectively. 
Chapters III - VII are further divided into sections which discuss aquatic, terrestrial, and wetland bioconcentration factors.

Additional bioconcentration factors are presented for sulfur-35, chromium-51, manganese-54, zinc-65, cerium144 , and radium-226. However, due to the limited amount of information, these are addressed in the Appendices.

Appendices $A$ and $B$ provide detailed tabular information on how bioconcentration factors were calculated, the location and number of samples, and the literature reference from which the bioconcentration factor was obtained. Aquatic, terrestrial, and wetland bioconcentration factors are given in Appendices A and B, respectively. Data in the Appendices are sorted first by radionuclide and second by the organism for which the bioconcentration factor is available.
The bioconcentration factors in this report were calculated from measured concentrations. In reporting each bioconcentration factor, the tissue or tissues of the organism analyzed are specified. Unless otherwise noted, bioconcentration factors are based on a dry weight basis,. If conversion factors were available in the publication for conversion to wet-weight, the conversion factor is also given.

The data presented within this report were collected by searching the literature for site-specific bioconcentration factors. All listed publications of Savannah River Ecology Laboratory (SREL) were reviewed and the appropriate documents obtained. A key word search of the PINT database and a review of SRS environmental monitoring reports yielded additional publications. 


\section{CONCEPT OF BIOCONCENTRATION FACTORS}

\section{Terminology}

Ecological risk occurs when biota are exposed to a consitutuent of concern (e.g., radiological or non-radiological contaminants). Effects from exposure are influenced by the species susceptibility, contaminant concentration, time, and other factors. Bioaccumulation refers to the uptake of a chemical by an organism through all routes of exposure, including ingestion, inhalation, and dermal absorption (Clarke and McFarland, 1991). Although a contaminant may be present in the environment, it may not be available to biota because it is chemically or physically isolated (e.g., bound to sediments or submerged). Thus, bioaccumulation depends upon bioavailability.

Two types of bioaccumulation are bioconcentration and biomagnification. Bioconcentration has typically been defined as the uptake of a chemical by an aquatic organism from water alone. However, this phenomenon is also applicable to terrestrial and semi-aquatic species which can achieve bioconcentration from other media such as sediment, soil, and the atmosphere. Chemicals that bioconcentrate include radioisotopes, organic compounds, and a small number of metals and organometals (EPA 1991). Biomagnification refers to an increased chemical concentation in an organism resulting from the ingestion of biota in other trophic levels.

The assimilation of a radionuclide in an organism is calculated by using a single empirical relationship to represent the transfer of the ionizing radiation from the media to the organism (Blaylock 1982). This dimensionless transfer coefficient is known as the bioconcentration factor (BCF). The BCF for an organism or tissue is also defined as the steady state ratio of radionuclide concentration in the organism or tissue to that in the reference medium (Vanderplog et al. 1975):

$\mathrm{BCF}=[\mathrm{C}]_{\text {org }} /[\mathrm{C}]_{\text {med }}$

where, $\mathrm{BCF}$ is the bioconcentration factor

$[\mathrm{C}]_{\text {org }}$ is the concentration of the radionuclide in the organism or tissue

$[C]_{\text {med }}$ is the concentration of the radionuclide in the specific medium (e.g., water, soil)
Bioconcentration factors can also be calculated by: (1) dividing the uptake rate, $k_{1}$, by the elimination rate, $k_{2}$ and (2) using structure-activity relationships based upon the relationship between the BCF and the n-octanol/water partitioning coefficient $(\log$ P) for organic chemicals (EPA, 1991).

The bioaccumulation factor (BAF) is similar to the $\mathrm{BCF}$ but it includes exposure to ionizing radiation from both the environment and ingestion of food. It is calculated by "adjusting" the BCF using a food chain multiplier (FM) for the organism of concern (EPA, 1991) as follows:

$\mathrm{BAF}=\mathrm{FM} \times \mathrm{BCF}$

The food chain multiplier is dependent upon the $\log \mathrm{P}$ of the chemical and the structure of the organism's food chain.

The emphasis of this report is bioconcentration factors. For aquatic habitats, bioconcentration factors were calculated with water being the reference medium. Terrestrial and wetland bioconcentration factors were calculated with soil as the reference medium. Any deviations will be noted in the comprehensive tables found in the Appendices.

The primary simplifying assumption (which will be used in this report) in using the bioconcentration factor is that the radionuclides are taken up directly from the reference material. However, this may not be entirely true in all cases. With aquatic bioconcentration factors, the organism may take up radionuclides from the sediment and/or food in addition to water. With terrestrial bioconcentration factors, uptake of radionuclides may occur from deposition or from food (at higher trophic levels).

Before using a bioconcentration factor, it is important to know if the bioconcentration factor chosen is appropriate for its intended use. Certain elements have an affinity for different tissues and these attributes will be reflected in the bioconcentration factor. For example, in dose assessment activities, bioconcentration factors for the edible portion of the organism are most important. However, in terms of ecological risk, whole-body bioconcentration factors may be most important. 


\section{Variability of Bioconcentration Factors}

Bioconcentration factors can vary greatly depending on environmental as well as experimental conditions. Each of these conditions must be considered when choosing the appropriate bioconcentration factor to use.

\section{Environmental Conditions}

There are numerous environmental conditions that will affect the bioconcentration factor for an organism. Some of these conditions, which are discussed below, include the length of residence in a contaminated area, species and individual uptake variations, the chemical state of the radionuclide, and contributions from deposition.

The length of residence in a contaminated area is an environmental condition that will affect both aquatic and terrestrial bioconcentration factors. Organisms, which are confined exclusively to the contaminated area, tend to have higher concentration factors than those organisms that are free to enter and leave the area (Whicker et al. 1989).

There will also be variations in uptake among species and among individuals within a species. The type of food chain, as well as the metabolism of an organism, will have an impact on uptake (Thompson et al., 1972). For terrestrial organisms, soil-to-plant concentration factors can also be expected to exhibit seasonal variation (Garten et al. 1975a).

The chemical state of the radionuclide will also affect the bioconcentration factor. Radionuclides exist in different chemical forms in aquatic and terrestrial systems, and their different forms have different availabilities to different organisms. In most cases, uptake of the radionuclide is similar to that of the stable element analog.

A major environmental condition to consider when determining a terrestrial bioconcentration factor is atmospheric deposition. Deposition must be considered because it overestimates the bioconcentration factor and does not give a true indication of uptake. In experimental studies of plantto-soil uptake, green house experiments are usually performed to eliminate overestimates from deposition. However, greenhouse results are difficult to extrapolate to field responses because of differences in climate and root growing conditions. Greenhouse experiments can, however, provide information relative to the effect of environmental factors on bioavailability which are often difficult to obtain from field experiments (Adriano et al. 1981a). Several terrestrial bioconcentration studies summarized in this report were performed in a greenhouse after soil samples were collected from the study area. If an experimental study was conducted in the field, it is noted in the table. The field experiments summarized in this document were not affected by deposition.

\section{Experimental Conditions}

Experimental conditions which affect bioconcentration factors are not dependent on the radionuclide or location. These variations result from artifacts of analysis and evaluation and presentation of data. Some experimental factors, which are discussed below, include sampling error, analytical error, and calculation methods.

Representative samples must be collected in order to obtain appropriate bioconcentration factors. Samples that are not representative will result in an inaccurate estimate of the true bioconcentration factor. It is also important for the organism and reference medium to have reached a steady state at the time of sample collection and measurement. If a steady state has not been reached, the bioconcentration factor will not be appropriate. For aquatic systems, collecting filtered or unfiltered water will also affect the bioconcentration factor. A significant fraction of some elements in water may be in the suspended particulate phase ( $90 \%$ in some cases); therefore, bioconcentration factors in filtered water samples may be much larger than bioconcentration factors in unfiltered water (Vanderplog et al. 1975).

When analyzing environmental samples, the concentrations of radionuclides or stable elements in most environmental samples are so low that serious problems can be encountered with their measurement (Vanderplog et al. 1975). Many radionuclides are below detection limits and can not be measured. In other cases, there may be a large uncertainty associated with a particular measurement. In most cases it is not possible to determine the analytical errors of the measurements associated with particular studies. Therefore, it is assumed that the analytical error associated with the measurements is negligible in relation to variations due to environmental conditions.

The calculation method can also have a significant influence on the bioconcentration factor. For example, bioconcentration factors expressed in terms of dry weight of the organism are higher than those calculated using fresh (i.e.wet) weight concentrations. In this report the fresh or dry weight information is given in the tables in Appendices $\mathrm{A}$ and $\mathrm{B}$.

It is also important to know from what tissue of the organism the bioconcentration factor was calculated. Some radi- 
onuclides have affinities for certain tissues and the bioconcentration factor will vary depending on how it is reported. Whole-body factors may not be the same as tissue-specific factors.

\section{Bioavailability of Radionuclides to Biota from Water and Sediment}

Aquatic organisms can assimilate radionuclides from their food, from direct uptake from water, or by both mechanisms (Reichle et al. 1970). Radionuclides exist in a wide variety of physiochemical forms in natural waters. Such forms include dissolved ionic species, inorganic associations, complexes with organic molecules, adsorption to and precipitation on solids, and incorporation in biological materials or crystalline structures (Vanderplog et al. 1975). These different forms have different availabilities to the aquatic food chain. Algae (unicellular and multicellular), for example, concentrate elements from the soluble phase. Aquatic vascular plants accumulate elements from both the soluble phase as well as from the interstitial water of sediment. Aquatic animals, especially filter feeders, may accumulate radionuclides from the suspended phase (Vanderplog et al. 1975).

Radionuclides enter the food webs not only from water, but also from bottom sediments; thus, the availability of some radionuclides to the food web will vary with sediment type. Benthic invertebrates accumulate radionuclides from bottom sediments. Fishes may accumulate radionuclides indirectly from bottom sediment by ingestion of benthic invertebrates and also directly by incidental ingestion of sediment with prey (Vanderplog et al. 1975).

The chemical composition of water can also influence the bioconcentration of radionuclides in biota. It has been established that for cesium, strontium, and cobalt there is a relationship between the bioconcentration factor and the chemical composition of the water. The bioconcentration of cesium is related to the concentration of potassium and suspended solids in the water. For strontium, the concentration of calcium in the water affects uptake of strontium in fish. The concentration of calcium does not appear the affect strontium uptake in other aquatic organisms. The uptake of cobalt appears to be affected by the eutrophy (as defined by the nutrient content) of the water; Uptake tends to decrease with increasing eutrophy of the water (Vanderplog et al. 1975).

\section{Bioavailability of Radionuclides to Biota from Soil}

The uptake of a radionuclide from soil by plants depends on various interrelated soil properties including texture, clay content, dominant clay mineral, cation exchange capacity, exchangeable cations, $\mathrm{pH}$, and organic matter content. Uptake also varies with the chemical and physical forms of the radionuclide, the plant species, plant part, stage of growth, as well as with management practice and the manner in which the radionuclide is introduced into the soil ( $\mathrm{Ng} \mathrm{1982).}$

When a radionuclide is introduced into the soil in soluble form, it can adsorb on clays, precipitate as an oxide or hydroxide, chelate with soil organic molecules, or remain in solution. The manner in which the radionuclide is distributed among these various fractions will determine how long it will remain at the site of deposition and the extent to which it will be available for uptake by plants (Eisenbud 1973).

As a general rule, radioisotopes present in soil will pass into the root system in the same manner as nonradioactive isotopes of the same or analogous cations. The element may or may not be required for normal metabolism, and some elements like iodine, cobalt, uranium, and radium are known to be present in plants although they serve no metabolic function (Eisenbud 1973). Radioisotopes of elements ordinarily present in soil and normally utilized in plant metabolism are absorbed in a manner independent of their radioactive properties. According to Nishita (1961), the relative uptake of radionuclides from soils is $\mathrm{Sr}>>\mathrm{I}>\mathrm{Ba}>\mathrm{Cs}, \mathrm{Ru}>\mathrm{Ce}>\mathrm{Y}, \mathrm{Pm}, \mathrm{Nb}, \mathrm{Zr}>\mathrm{Pu}$. Uptake of long-lived radionuclides by plants from the soil depends on whether the radionuclide is within the reach of the plant's roots and the extent to which the radionuclide is chemically available. ...

Determining bioconcentration factors at higher trophic levels introduces more variables which may affect the bioconcentration factor. Terrestrial organisms can assimilate radionuclides from any combination of their food, from direct uptake from soil, or by deposition. Species composition and food preferences, as well as radionuclide assimilation and turnover rates, will also influence trophic transfer. At the top of the food chain, species can assimilate radionuclides through the respiratory tract, skin, and gastrointestinal track (usually the most important) (Reichle et al. 1970). 


\section{CESIUM}

\section{Introduction}

Cesium is one of the principal radionuclides released from SRS operations. It is the major contributor to the maximum individual dose from liquid releases (consumption of fish) and a minor contributor to dose (<1\%) from atmospheric releases (Carlton, et al. 1992a). Although Cs-134 and Cs-137 were both produced at the SRS, Cs-137 is emphasized in this report because of its longer half-life (30.2 yrs versus 2.06 yrs). Cesium-137, which technically is a beta emitter, decays into barium which is a gamma emitter.

Radiocesium at SRS originated primarily in the fuel and targets that were irradiated during nuclear materials production. The greatest releases of $\mathrm{Cs}-137$ were to onsite seepage basins and site streams during the early years of operation. The majority of cesium was released from the separations areas which are located in $\mathrm{F}$ and $\mathrm{H}$ areas of the site (Carlton, et al. 1992a). Approximately 1,900 Ci of cesium has been released to seepage basins and streams and $4 \mathrm{Ci}$ of cesium has been released to the atmosphere (Cummins et al. 1991a).

\section{Aquatic Bioconcentration Factors}

Cesium is one of the rarest alkali metals and exists primarily as free ions in solution. Because of cesium's large size and small charge, it does not tend to form complex ions in solution. However, cesium is strongly adsorbed by suspended materials, especially clays and can be removed from the soluble phase to varying degrees (Vanderplog et al. 1975).

The aquatic food chain accumulates cesium not only from the soluble phase of water but also from suspended and bottom sediments and from absorption from food. However, most of the uptake is expected to result from ingestion of sediment or ingestion of prey that has ingested sediment. Differences in sediment type among water bodies contribute to the variability in uptake of cesium-137 in aquatic organisms.
The concentration of cesium in the soluble phase tends to decrease with increasing suspended solids concentration (Vanderplog et al. 1975). Organisms which accumulate cesium from the soluble phase will usually have lower bioconcentration factors at higher suspended solids concentrations than the same organisms at lower suspended solids concentrations.

Because of the chemical similarities and relative abundances of cesium and potassium, the bioconcentration factor for cesium in aquatic organisms (except algae) can be related to the concentration of potassium in the water (Vanderplog et al. 1975). Bioconcentration factors tend to increase with decreasing concentrations of potassium in water. Elevated concentration factors for cesium in aquatic species at SRS have been associated with low concentrations of potassium in water (Whicker et al. 1990).

Aquatic bioconcentration factors for cesium-137 are summarized in Table 3-1. More detailed information about the conditions for which the bioconcentration factor was calculated is found in Appendix A.

Site-specific bioconcentration factors for algae ranged from 1,200 to 4,500. Zooplankton had a bioconcentration factor of 71,000. Bioconcentration factors for benthic macroinvertebrates at SRS ranged from 8,000 to 12,000 . Whicker et al. (1989) reported that the elevated bioconcentration factors for the zooplankton and benthic macroinvertebrates were probably due to the high surface to volume ratios of the organisms; thus allowing their surfaces, as well as their guts, to carry measurable cesium137 activity.

The maximum bioconcentration factor for aquatic macrophytes, 37,000, was found in Fanwort, a rooted vascular plant (Table 3-1). Bladderwort, a floating vascular plant, had a bioconcentration factor of 17,000. The emergent wetland plants, knotweed and smartweed, had the lowest bioconcentration factors, with a range from 716 to 3,420 in the leaves.

Because fish may accumulate cesium from bottom sediment by ingestion of benthic invertebrates and also by 
ingestion of sediment with prey (Vanderplog et al. 1975), fish were divided into categories in this report based on their feeding habits. The maximum bioconcentration factor for all fish (muscle) was 48,000 in the gizzard shad, which feeds on detritus and plankton. For surface and midwater insectivores (shiners and mosquitofish), bioconcentration factors ranged from 891 to 11,300 . For insect and bottom invertebrate feeders (bluegill, sunfish, pirate perch), bioconcentration factors in the flesh ranged from 691 to 1,330 . For piscivores (bass and pickerel), bioconcentration factors ranged from 908 to 39,000 . For benthic invertebrate and fish feeders (catfish), bioconcentration factors ranged from 1,200 to 29,000 .

Freshwater shrimp and crayfish had bioconcentration factors of 867 and 997, respectively. Bioconcentration factors in the soft tissue of clams ranged from 220 to 300 .

Wildlife species also had high bioconcentration factors. Waterfowl (composite of 7 samples) had a bioconcentration factor of 19,000 in the muscle. A composite of 10 turtles had a bioconcentration factor of 13,000 in the muscle. Water snakes (composite of 2 ) had a bioconcentration factor of 2,600 .
These site-specific bioconcentration factors are orders of magnitude higher than values reported in the literature. As stated earlier, the relatively high bioconcentration factors of cesium-137 in fish flesh can be largely explained by the low concentrations of potassium in the water.

Bioconcentration factors for selected flora and fish inhabiting SRS impoundments are given in Table 3-2. These values were based on samples taken from Par Pond, L-Lake, Pond C, and Pond S in 1995 and 1996 by SREL (Hinton, 1996). Ranges, Standard errors, and other statistics for these data are provided in Appendix A, Table A-2.

Except for Nymphoides aquatica which had the highest bioconcentration factor, values for rooted floating macrophytes generally ranged between 11,000 and 21,000 (Table 3-2). Panicum and Pontederia had the lowest BCF values whereas submerged macrophytes had intermediate values. Large-mouth bass had a BCF of 14,778 based on a sample size of 975 fish. 
Table 3-1: Bioconcentration Factors for Cesium in Aquatic Ecosystems (Cummins, 1994).

\begin{tabular}{|c|c|c|c|c|c|c|c|}
\hline \multirow[b]{2}{*}{ Cesium-137 } & \multicolumn{4}{|c|}{ SRS Calculated Values } & \multicolumn{3}{|c|}{ Non-SRS Values } \\
\hline & Minimum & Maximum & Mean $^{\mathrm{a}}$ & $N^{b}$ & $\begin{array}{c}\text { Literature } \\
\text { Ranges }\end{array}$ & $\begin{array}{c}\text { Vanderplog } \\
\text { Recommendation }\end{array}$ & $\begin{array}{c}\text { NRC } \\
\text { Values }^{d}\end{array}$ \\
\hline Algae & 1,200 . & 4,500 & & 2 & $1,016-3,400$ & 1,000 & \\
\hline Beetles & & 480 & & 1 & & & \\
\hline Clam, tissue & 220 & 300 & & 1 & $42-600$ & & \\
\hline Clam, shell \& bone & & 25 & & 1 & & & \\
\hline Detritus & & 938 & & 1 & & & \\
\hline $\begin{array}{l}\text { Fish muscle (surface and } \\
\text { midwater insectivores) }\end{array}$ & 891 & 11,300 & 7,009 & 8 & & $\begin{array}{c}5,000 /[\mathrm{K}]_{\mathrm{w}} \mathrm{e,f} \\
1,000 /[\mathrm{K}]_{\mathrm{w}} \mathrm{g}\end{array}$ & 2,000 \\
\hline $\begin{array}{l}\text { Fish muscle (Insect and bottom } \\
\text { invertebrate feeders) }\end{array}$ & 691 & 1,334 & 911 & 4 & $410-9,500$ & $\begin{array}{c}5,000 /[\mathrm{K}]_{\mathrm{W}} \mathrm{e,f} \\
1,000 /[\mathrm{K}]_{\mathrm{w}} \mathrm{g}\end{array}$ & 2,000 \\
\hline Fish muscle (Piscivores) & 908 & 39,000 & 10,980 & 5 & $400-14,000$ & $\begin{array}{c}15,000 /\left[\mathrm{K}_{\mathrm{w}}\right]^{\mathrm{e}, \mathrm{f}} \\
3,000 /[\mathrm{K}]_{\mathrm{w}} \mathrm{g}\end{array}$ & 2,000 \\
\hline $\begin{array}{l}\text { Fish muscle (Benthic } \\
\text { invertebrate and fish feeders) }\end{array}$ & 1,200 & 29,000 & & 2 & $1,200-6,800$ & $\begin{array}{c}5,000 /[\mathrm{K}]_{\mathrm{w}} \mathrm{e,f} \\
1,000 /[\mathrm{K}]_{\mathrm{w}} \mathrm{g}\end{array}$ & 2,000 \\
\hline $\begin{array}{l}\text { Fish muscle (detritus and } \\
\text { plankton feeders) }\end{array}$ & & 48,000 & & 1 & $40-510$ & $\begin{array}{c}5,000 /[\mathrm{K}]_{\mathrm{W}} \mathrm{e,f} \\
1,000 /[\mathrm{K}]_{\mathrm{W}} \mathrm{g}\end{array}$ & 2,000 \\
\hline $\begin{array}{l}\text { Fish bone (Insect and bottom } \\
\text { invertebrate feeders) }\end{array}$ & & 600 & & 1 & $430-1,182$ & $\begin{array}{r}5,000 /[\mathrm{K}]_{\mathrm{w}} \mathrm{e,f} \\
1,000 /[\mathrm{K}]_{\mathrm{w}} \mathrm{g}\end{array}$ & \\
\hline Fish bone (Piscivores) & & 500 & & 1 & $700-1,430$ & $\begin{array}{c}15,000 /[\mathrm{K}]_{\mathrm{w}} \mathrm{e}, \mathrm{f} \\
3,000 /[\mathrm{K}]_{\mathrm{w}} \mathrm{g}\end{array}$ & \\
\hline $\begin{array}{l}\text { Fish bone (Benthic invertebrate } \\
\text { and fish feeders) }\end{array}$ & & 800 & & 1 & $40-9,500$ & $\begin{array}{c}5,000 /[\mathrm{K}]_{w}{ }^{e, f} \\
1,000 /[K]_{w} g\end{array}$ & \\
\hline
\end{tabular}


Table 3-1: Bioconcentration Factors for Cesium in Aquatic Ecosystems (Cummins, 1994) (cont'd).

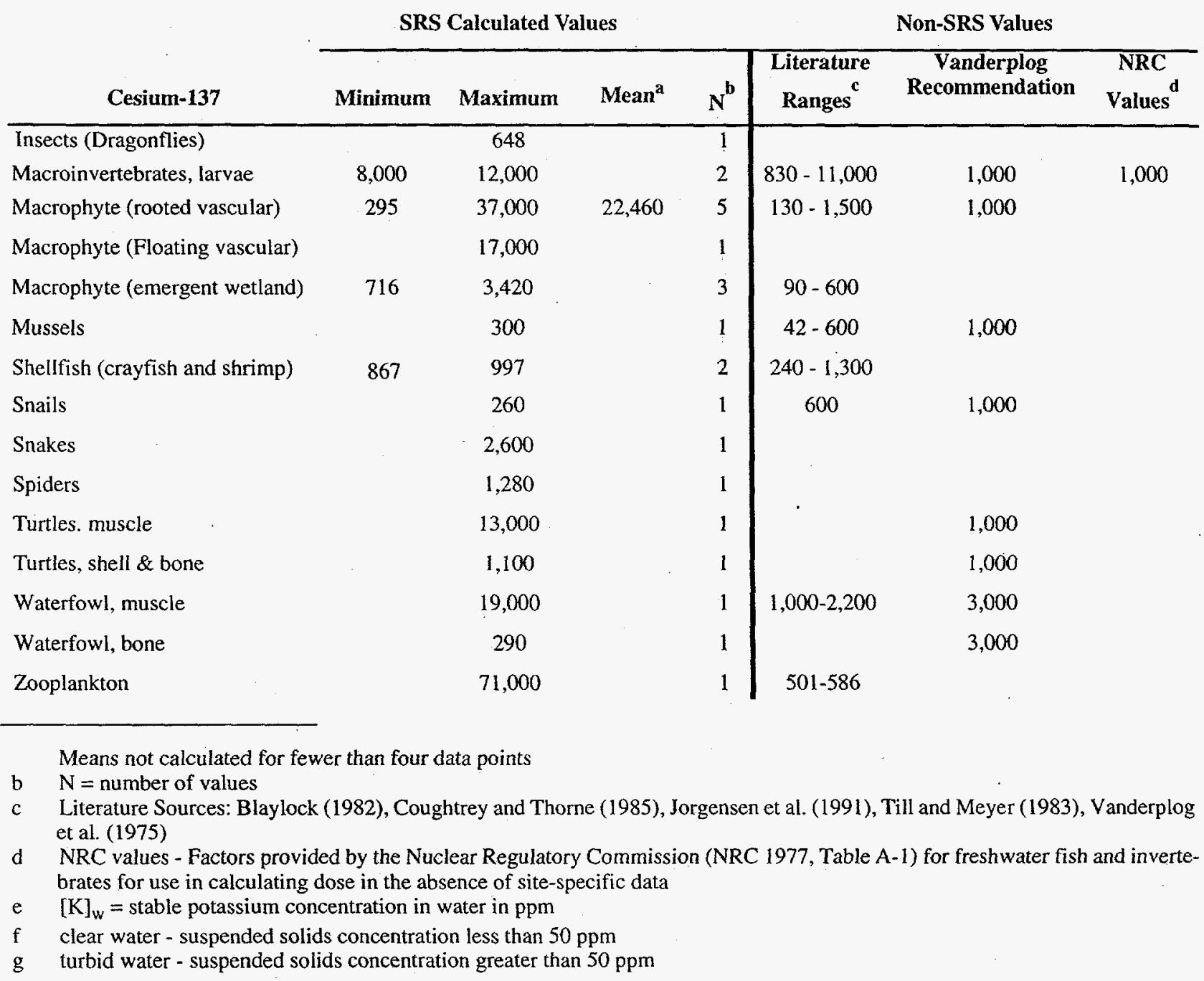


Table 3-2:Bioconcentration Factors for Cs-137 in Selected Biota at SRS Impoundments 1993-1996 (Hinton, 1996).

\begin{tabular}{llrr}
\hline \multicolumn{1}{c}{ Life Form } & \multicolumn{1}{c}{ Scientific Name } & BCF & N \\
\hline Rooted Floating Macophytes & Hydrocotyle umbrelleta & 19,068 & 2 \\
& Brasenia schreberi & 15,573 & 23 \\
& Nelumbolutea & 20,995 & 57 \\
& Nymphaea odorata & 11,526 & 61 \\
& Nymphoides aquatica & 52,497 & 2 \\
& Nymphoides spp. & 11,355 & 1 \\
& & & \\
Submerged Macrophytes & Cabomba caroliniana & 42,106 & 5 \\
& Myriophyllum spicatum & 26,407 & 44 \\
& Najasodorata & 4,900 & 3 \\
& Najasminor & 5,413 & 30 \\
& Vallisneria americana & 2,983 & 31 \\
& & & \\
Grasses, Sedges, and Rushes & Panicum hemitomon & 1,107 & 12 \\
& & & \\
Emergent Macrophytes & & & 3 \\
& Pontederia cordata & 1,618 & 15 \\
& Sagittaria latifolia & 22,008 & 28 \\
& Typha latifolia & 3,707 & \\
Piscivorous Fish & Micropterus salmoides & 14,778 & 975
\end{tabular}




\section{Terrestrial and Wetland Bioconcentration Factors}

Table 3-3 summarizes the terrestrial and wetland bioconcentration factors for cesium-137. Uptake of cesium-137 by plants from soil decreases with increasing concentrations of exchangeable potassium in the soil. Elevated concentration factors for cesium have been associated with soils of high organic matter content, low $\mathrm{pH}$, or low clay

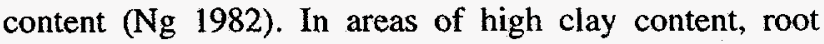
uptake of cesium is slight and folial absorption is the main portal of entry of cesium-137 into the food web (Eisenbud 1973).

Native flora, including alder, arrowhead, fungi, myrtle, pine, red maple, smartweed, turkey oak, water tupelo, and willow, have been studied in the field to determine cesium137 uptake. Contributions from deposition were negligible. Individual bioconcentration factors for native flora ranged from 0.39 in smartweed stems to 27.9 in smartweed roots. Both samples were collected from Steel Creek. Uptake in the plant leaves ranged from 0.0053 in pine trees to 20.8 in arrowhead.

Numerous greenhouse studies on grasses and agricultural crops have also been performed. Cesium-137 uptake has been determined for corn, soybeans, wheat, bahia grass, and clover. Bioconcentration factors in the grasses ranged from 0.8 in clover to 7.59 in Bahia grass. Mean bioconcentration factors for agricultural crops were 0.56 for corn, 0.50 for soybeans, and 0.10 for wheat.

The site-specific bioconcentration factors determined for plants and grasses are higher than values reported in the literature (Table 2) and are probably due to the low clay content of the soils at the SRS.

Anderson et al. (1973) studied the relationships between the levels of cesium-137 in plants and arthropods in Steel Creek. This has been the only site-specific study to determine cesium accumulation and movement throughout a large wetland system. The results of this study produced an average bioconcentration factor of 0.51 for primary consumers to primary producers and an average bioconcentration factor of 0.96 for secondary consumers to primary consumers.

Bioconcentration of cesium-137 in SRS deer has also been studied. Bioconcentration factors for white-tailed deer (muscle) on the SRS range from 0.22 to 4.8 . These values are comparable to literature values. 
Table 3-3: Bioconcentration Factors for Cs-137 in Terrestrial and Wetland Ecosystems (Cummins, 1994).

SRS Calculated Values

Non-SRS Values

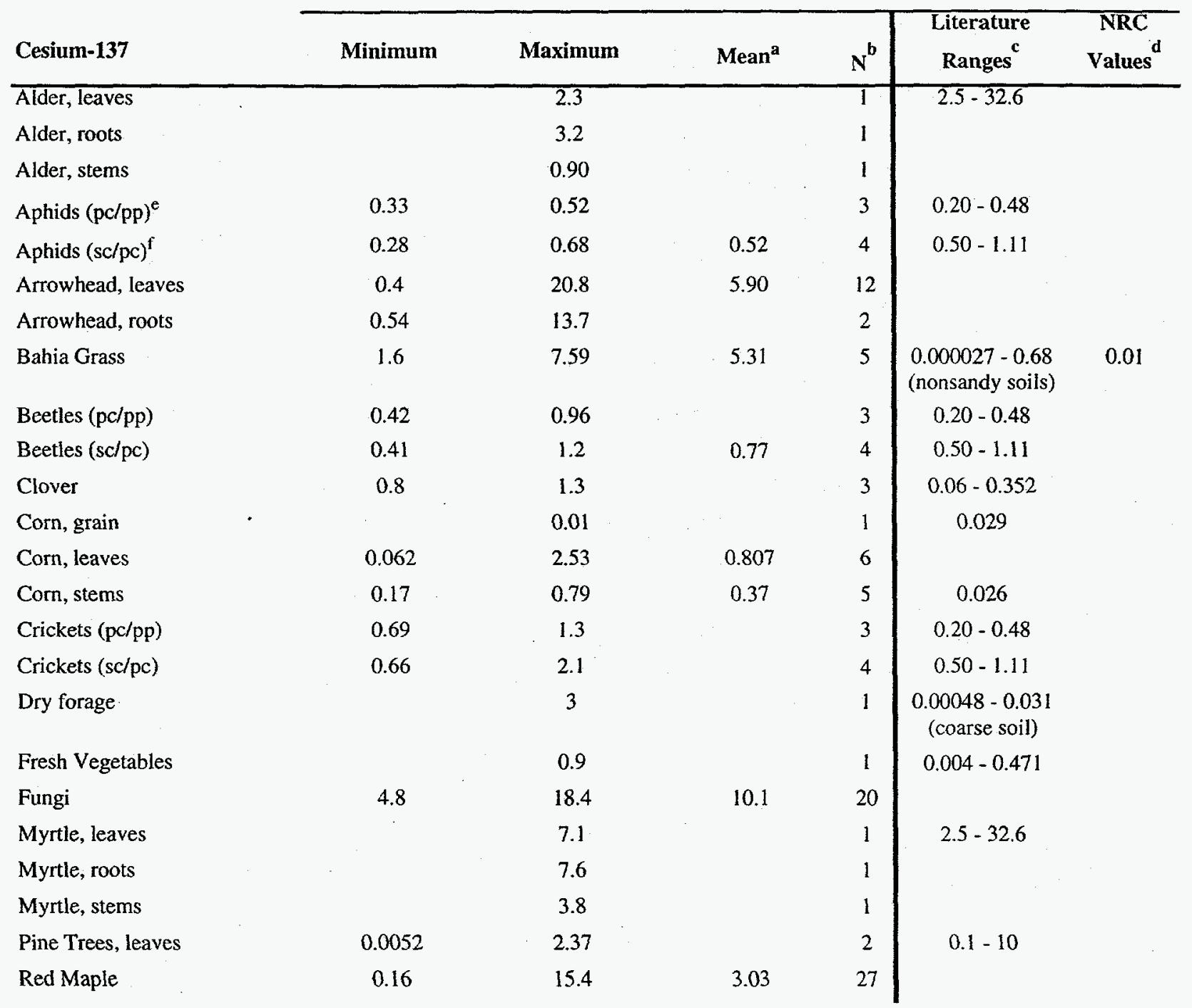

Means not calculated for fewer than four data points

$\mathrm{N}=$ Number of values

c Literature Sources: Anderson et al. (1973), Crossley (1963 and 1969), Dahlman et al (1975), Evans and Decker (1968), Hardy and Bennett (1977), Haselow (1991), Marei et al. (1972), Miller (1963), Nishita et al. (1958), Ng (1982), Till and Meyer (1983)

d NRC values - Factors for fresh-weight vegetation provided by the Nuclear Regulatory Commission (NRC 1977, Table E-1) for use in calculating dose in the absence of site-specific data

e $\quad p c / p p=$ primary consumer to primary producer bioconcentration factor

f $\quad \mathrm{sc} / \mathrm{pc}=$ secondary consumer to primary consumer bioconcentration factor 
Table 3-3: Bioconcentration Factors for Cs-137 in Terrestrial and Wetland Ecosystems (Cummins, 1994)(cont'd).

\begin{tabular}{|c|c|c|c|c|c|c|}
\hline \multirow[b]{2}{*}{ Cesium-137 } & \multicolumn{4}{|c|}{ SRS Calculated Values } & \multicolumn{2}{|c|}{ Non-SRS Values } \\
\hline & Minimum & Maximum & Mean $^{a}$ & $N^{b}$ & $\begin{array}{c}\text { Literature } \\
\text { Ranges }\end{array}$ & $\begin{array}{c}\text { NRC } \\
\text { Values }\end{array}$ \\
\hline Rice, foliage & 0.53 & 0.96 & 0.73 & 4 & & \\
\hline Rice, grain & 0.36 & 0.70 & 0.53 & 4 & & \\
\hline Smartweed, leaves & 0.60 & 11.8 & 3.49 & 4 & & \\
\hline Smartweed, roots & 0.84 & 27.9 & & 2 & & \\
\hline Smartweed, stems & 0.39 & 12.2 & & 2 & & \\
\hline Snakes & & 2.94 & & 1 & & \\
\hline Soybeans, bean & 0.26 & 1.66 & 0.70 & 5 & & \\
\hline Soybeans, stems & 0.14 & 0.37 & 0.22 & 5 & & \\
\hline Spiders $(p c / p p)^{e}$ & 0.45 & 0.92 & & 3 & $0.20-0.48$ & \\
\hline Spiders $(s c / p c)^{f}$ & 0.41 & 1.3 & & 4 & $0.50-1.11$ & \\
\hline $\begin{array}{l}\text { Tree bark (maple, } \\
\text { sweetgum, and poplar) }\end{array}$ & & 0.039 & & 1 & & \\
\hline $\begin{array}{l}\text { Tree leaf (maple, } \\
\text { sweetgum, and poplar) }\end{array}$ & & 0.27 & & 1 & & \\
\hline $\begin{array}{l}\text { Tree wood (maple, } \\
\text { sweetgum, and poplar) }\end{array}$ & & 0.11 & & 1 & & \\
\hline Turkey Oak & 7.9 & 25.7 & & 3 & & \\
\hline Water Tupelo, leaves & 0.41 & 0.85 & & 2 & & \\
\hline Water Tupelo, roots & 3.2 & 7.0 & & 2 & & \\
\hline Water Tupelo, stems & 0.72 & 4.0 & & 2 & & \\
\hline Wheat, grain & 0.06 & 0.18 & 0.1 & 4 & $0.0017-0.045$ & \\
\hline White-tailed Deer, muscle & 0.22 & 4.8 & 1.56 & 8 & $0.6-3.3$ & \\
\hline Willow, leaves & & 3.8 & & 1 & $2.5-32.6$ & \\
\hline Willow, roots & & 6.2 & & 1 & & \\
\hline Willow, stems & & 1.3 & & 1 & & \\
\hline
\end{tabular}

a Means not calculated for fewer than four data points

b $\quad \mathrm{N}=$ Number of values

c Literature Sources: Anderson et al. (1973), Crossley (1963 and 1969), Dahlman et al (1975), Evans and Decker (1968), Hardy and Bennett (1977), Haselow (1991), Marei et al. (1972), Miller (1963), Nishita et al. (1958), Ng (1982), Till and Meyer (1983)

d NRC values - Factors for fresh-weight vegetation provided by the Nuclear Regulatory Commission (NRC 1977, Table E-1) for use in calculating dose in the absence of site-specific data

e $\quad \mathrm{pc} / \mathrm{pp}=$ primary consumer to primary producer bioconcentration factor

f $\mathrm{sc} / \mathrm{pc}=$ secondary consumer to primary consumer bioconcentration factor 


\section{STRONTIUM}

\section{Introduction}

Radiostrontium at SRS originated primarily in the fuel and targets that were irradiated in the nuclear materials production areas. The greatest releases of strontium occurred during the early years of operation in the reactor facilities when strontium was released to onsite seepage basins and site streams (Carlton et al. 1992b). Approximately $104 \mathrm{Ci}$ of strontium has been released to seepage basins and streams and $3 \mathrm{Ci}$ of strontium has been released to the atmosphere (Cummins et al. 1991a). Strontium-90 has a half-life of 28 years and is the primary radioisotope that is considered in this report. Strontium89,90 is also considered, but it is assumed that all of the strontium present is strontium-90 (half life of Strontium89 is 52 days).

\section{Aquatic Bioconcentration Factors}

Strontium has physiochemical properties similar to calcium and both appear mainly in ionic form in water. Strontium is not strongly sorbed by suspended particulate matter in water and is thus available in the water for uptake.

The primary means of calcium and strontium uptake in most aquatic organisms is directly from the water. The gill membrane of fishes are the primary sites of calcium and strontium taken up by fishes is through the food chain. Therefore, trophic level appears to have little effect on the bioconcentration factor of strontium (Vanderplog et al. 1975). A negative correlation has been demonstrated between the concentration of calcium in water and the strontium uptake in fish (Blaylock 1982: Vanderplog et al. 1975).

Table 4-1 summarizes the site-specific bioconcentration factors for strontium. The site-specific bioconcentration factor for strontium in blue-green algae was 600 . For strontium in macroinvertebrates, bioconcentration factors were 520 in insect nymph larvae and 54,000 in gastropod larvae.

For macrophytes, bioconcentration factors ranged from 2,100 in the white-water lily (rooted vascular plant) to 9,400 in bladderwort (floating vascular plant).

Because of strontium's similarity to calcium, the maximum bioconcentration factors for strontium in vertebrates are found in the bone. Bioconcentration factors in fish bone ranged from 1,700 in piscivores (large-mouth bass) to 63,000 (also piscivores). Muscle bioconcentration factors in fish were $<48$.

The strontium-90 bioconcentration factors calculated for SRS aquatic systems are higher than those reported in the. literature (Table 4-1). 
Table 4-1: Bioconcentration Factors for Strontium in Aquatic Ecosystems (Cummins, 1994).

\begin{tabular}{|c|c|c|c|c|c|c|c|}
\hline \multirow[b]{2}{*}{ Strontium-89,90 } & \multicolumn{4}{|c|}{ SRS Calculated Values } & \multicolumn{3}{|c|}{ Non-SRS Values } \\
\hline & Minimum & Maximum & Mean $^{a}$ & $N^{b}$ & $\begin{array}{c}\text { Literature } \\
\text { Ranges }^{c}\end{array}$ & $\begin{array}{c}\text { Vanderplog } \\
\text { Recommendation }\end{array}$ & $\begin{array}{c}\text { NRC } \\
\text { Values }\end{array}$ \\
\hline Algae & & 600 & & 1 & $120-2,300$ & 2,000 & \\
\hline $\begin{array}{l}\text { Fish muscle (Insect and } \\
\text { bottom invertebrate feeders) }\end{array}$ & & $<48$ & & 1 & $1.7-92$ & $5.18-1.21 \ln [\mathrm{Ca}]_{\mathrm{w}} \mathrm{e}$ & 30 \\
\hline Fish muscle (Piscivores) & & $<48$ & & 1 & $1.3-125$ & $5.18-1.21 \ln [\mathrm{Ca}]_{\mathrm{w}}$ & 30 \\
\hline $\begin{array}{l}\text { Fish muscle (Benthic } \\
\text { invertebrate and fish } \\
\text { feeders) }\end{array}$ & & $<48$ & & 1 & & $5.18-1.21 \ln [\mathrm{Ca}]_{\mathrm{W}}$ & 30 \\
\hline $\begin{array}{l}\text { Fish bone (Insect and bottom } \\
\text { invertebrate feeders) }\end{array}$ & & 2,400 & & 1 & $50-8,810$ & $5.18-1.21 \ln [\mathrm{Ca}]_{\mathrm{W}}$ & \\
\hline Fish bone (Piscivores) & & 1,700 & & 1 & 2,400 & $5.18-1.21 \ln [\mathrm{Ca}]_{\mathrm{W}}$ & \\
\hline $\begin{array}{l}\text { Fish bone (Benthic } \\
\text { invertebrate and fish } \\
\text { feeders) }\end{array}$ & & 2,100 & & 1 & $2,400-8,000$ & $5.18-1.21 \ln [\mathrm{Ca}]_{\mathrm{W}}$ & \\
\hline Strontium-90 & Minimum & Maximum & Mean $^{a}$ & $N^{b}$ & $\begin{array}{c}\text { Literature } \\
\text { Ranges }^{c}\end{array}$ & $\begin{array}{c}\text { Vanderplog } \\
\text { Recommendation }\end{array}$ & $\begin{array}{c}\text { NRC } \\
\text { Values }\end{array}$ \\
\hline Clam, shell & & 1,330 & & 1 & $2,640-3,246$ & $6.8 \mathrm{E} 04 /[\mathrm{Ca}]_{\mathrm{w}}{ }^{\mathrm{e}}$ & \\
\hline Fish muscle (Piscivores) & & 3,400 & & 1 & $1.3-125$ & $5.18-1.21 \ln [\mathrm{Ca}]_{\mathrm{W}}$ & 30 \\
\hline $\begin{array}{l}\text { Fish muscle (Benthic } \\
\text { invertebrate and fish } \\
\text { feeders) }\end{array}$ & & 610 & & 1 & & $5.18-1.21 \ln [\mathrm{Ca}]_{\mathrm{W}}$ & 30 \\
\hline Fish bone (Piscivores) & & 63,000 & & 1 & 2,400 & $5.18-1.21 \ln [\mathrm{Ca}]_{\mathrm{w}}$ & \\
\hline $\begin{array}{l}\text { Fish bone (Benthic } \\
\text { invertebrate and fish } \\
\text { feeders) }\end{array}$ & & 57,000 & & 1 & $50-8,810$ & $5.18-1.21 \ln [\mathrm{Ca}]_{\mathrm{W}}$ & \\
\hline $\begin{array}{l}\text { Fish bone (detritus and } \\
\text { plankton feeders) }\end{array}$ & & 51,000 & & 1 & 2,400 & $5.18-1.21 \ln [\mathrm{Ca}]_{w}$ & \\
\hline Macroinvertebrates, larvae & 520 & 54,000 & 27,300 & 2 & $300-720$ & & 100 \\
\hline $\begin{array}{l}\text { Macrophytes (Rooted } \\
\text { vascular) }\end{array}$ & 2,100 & 8,500 & 5,500 & 4 & $3-240$ & & \\
\hline $\begin{array}{l}\text { Macrophytes (Floating } \\
\text { vascular) }\end{array}$ & & 9,400 & & 1 & $30-240$ & & \\
\hline Zooplankton & & 3,900 & & 1 & $0.1-10$ & & \\
\hline
\end{tabular}

a Mean not calculated for fewer than four data points

b $\quad \mathrm{N}=$ Number of Values

c Literature Sources: Blaylock (1982), Coughtrey and Thorne (1985), Till and Meyer (1983), Vanderplog et al. (1975)

d NRC values - Factors provided by the Nuclear Regulatory Commission (NRC 1977, Table A-1) for freshwater fish and invertebrates for use in calculating dose in the absence of site-specific data

e $\quad[\mathrm{Ca}]_{\mathrm{w}}=$ stable calcium concentration in water in ppm 


\section{Terrestrial and Wetland Bioconcentration Factors}

Strontium is soluble in water, is poorly retained in SRS soils, and is thus, subject to migration and uptake. The exchangeable calcium in soil is the most important factor in determining the extent of strontium absorption by plant roots $(\mathrm{Ng} \mathrm{1982)}$. The bioconcentration factor for strontium has been shown to be negatively correlated with the exchangeable calcium in the soil. The bioconcentration factor also decreases with increasing clay and organic matter in the soil.

Russell and Squire (1958) made some general conclusions about the physiology of strontium absorption and distribution in vegetation: (1) an equilibrium does not occur between strontium in the shoots and in the roots, (2) upward translocation appears to be an irreversible pro- cess, (3) very little redistribution of strontium occurs in the plant, and (4) the greatest accumulation of strontium occurs in the leaves.

Table 4-2 summarizes terrestrial and wetland site-specific bioconcentration factors. Site-specific bioconcentration factors for strontium-90 in agricultural crops ranged from 0.15 in corn grain to 13.1 in corn leaves. In native flora, concentration factors ranged from 0.81 in tree wood to 11 in tree bark. Concentration factors for tree leaves ranged from 0.88 in pine trees to 3.8 in a composite sample containing maple, sweetgum, and poplar. These bioconcentration factors are comparable to those observed in other sandy, southeastern soils.

Table 4-2: Bioconcentration Factors for Strontium in Terrestrial and Wetland Ecosystems (Cummins, 1994).

\begin{tabular}{|c|c|c|c|c|c|c|}
\hline \multirow[b]{2}{*}{ Strontium-90 } & \multicolumn{4}{|c|}{ SRS Calculated Values } & \multicolumn{2}{|c|}{ Non-SRS Values } \\
\hline & Minimum & Maximum & Mean $^{2}$ & $\mathbf{N}^{b}$ & $\begin{array}{l}\text { Literature } \\
\text { Ranges }\end{array}$ & $\begin{array}{l}\text { NRC } \\
\text { Values }\end{array}$ \\
\hline Corn, grain & & 0.15 & & 1 & $0.034-0.11$ & 0.017 \\
\hline Corn, leaves & . & 13.1 & & 1 & & \\
\hline Pine Trees, leaves & 0.88 & 1.69 & & 2 & $0.1-20$ & \\
\hline Soybeans & & 2.51 & & 1 & & \\
\hline $\begin{array}{l}\text { Tree wood (maple, } \\
\text { sweetgum, and poplar) }\end{array}$ & & 0.81 & & 1 & & \\
\hline $\begin{array}{l}\text { Tree bark (maple, } \\
\text { sweetgum, and poplar) }\end{array}$ & & 11 & & 1 & & \\
\hline $\begin{array}{l}\text { Tree leaf (maple, } \\
\text { sweetgum, and poplar) }\end{array}$ & & 3.8 & & 1 & & \\
\hline $\begin{array}{ll}\text { a } & \text { Mean not calculated fo } \\
\text { b } & N=\text { Number of values } \\
\text { c } & \text { Literature Sources: C } \\
\text { d } & \text { NRC values - Factors } \\
& \text { sion (NRC } 1977 \text {, Tabl }\end{array}$ & $\begin{array}{l}\text { wer than fou } \\
\text { frey and Thr } \\
\text {-1) for use in }\end{array}$ & $\begin{array}{l}\text { points } \\
\text { 1985) and } \mathrm{N} \\
\text { tation provi } \\
\text { lating dose i }\end{array}$ & $\begin{array}{l}\text { 2) } \\
\text { the Nence } \\
\text { bsence }\end{array}$ & & mis- & \\
\hline
\end{tabular}




\section{COBALT}

\section{Introduction}

Two principal sources of radiocobalt in natural environments are the result of fallout from nuclear weapons detonation and from nuclear reactor and fuel reprocessing operations. At the SRS, cobalt 60 has been released primarily to aquatic systems, and to a lesser extent to terrestrial systems. Cobalt- 60 is a negligible contributor to dose at SRS (<1\%) (Arnett et al. 1993). Approximately $84 \mathrm{Ci}$ of cobalt -60 has been released to onsite streams and seepage basins, whereas $0.1 \mathrm{Ci}$ has been released to the atmosphere (Cummins et al. 1991a). Cobalt-60 is a gamma emitter, has a half-life of 5.3 years, and is the primary radioisotope of cobalt considered in this report.

\section{Aquatic Bioconcentration Factors}

When in solution, cobalt tends to form complexes with dissolved organic matter, making the cobalt less available for uptake. Vanderplog et al. (1975) noted that cobalt bio concentration factors tend to decrease with increasing eutrophy (as defined by the nutrient content) of water. Cobalt is an essential component of vitamin $B_{12}$ and is a nutritional requirement for fish health. The highest concentrations of cobalt are found in the kidney and spleen; cobalt does not concentrate in fish muscle (Posten and Klopfer 1988). Cobalt is also an essential element for some bacteria, fungi, several species of blue green algae and several species of mammals. Therefore, uptake of the radioisotope is expected in these organisms.

Harvey (1969) conducted the only study at SRS to determine a bioconcentration factor for cobalt- 60 in aquatic systems. The bioconcentration factor for the soft tissue of clams was 790. Although it is not known from where these samples were taken onsite, the value can be compared to the 10,000 bioconcentration factor for cobalt in mesotrophic and oligotrophic waters or 400 bioconcentration factor for cobalt in eutrophic waters (Vanderplog et al. 1975). The NRC-recommended bioconcentration factor for freshwater invertebrates is 200 (NRC 1977, Table A-1). 


\section{Terrestrial and Wetland Bioconcentration Factors}

Cobalt is taken up by plants, although it is not an essential element for higher plants. It is, however, an essential element in animal nutrition (Adriano et al. 1977).

Table 5-1 summarizes terrestrial and wetland bioconcentration factors for cobalt. Adriano et. al (1977) studied the uptake of cobalt- 60 by bush beans and corn in Dothan and Troup soils. The results indicated that uptake of cobalt- 60 was affected by plant species and soil type. Bean leaves preferentially accumulated cobalt- 60 in comparison with corn leaves. Concentration factors in the bush beans ranged from 0.4 in the Troupe soil to 2.82 in the Dothan soil. Bioconcentration factors in the corn ranged from 0.13 in the Troupe soil to 0.56 in the Dothan soil. Bioconcentration factors for the corn were highest in the leaf.
Murphy (1992) studied the uptake of radionuclides, including cobalt-60, at the Savannah River Laboratory (SRL) seepage basins and reports bioconcentration factors of 0.61 and 0.018 in pine trees in the SRL Basin 4 and around the basin edge, respectively.

Table 5-1: Bioconcentration Factors for Cobalt in Terrestrial and Wetland Ecosystems (Cummins, 1994).

\begin{tabular}{lccc|cc} 
& \multicolumn{3}{c}{ SRS Calculated Values } & \multicolumn{2}{c}{ Non-SRS Values } \\
\cline { 2 - 6 } Cobalt-60 & Minimum & Maximum & Mean & $\mathbf{N}^{\mathbf{a}}$ & $\begin{array}{c}\text { Literature } \begin{array}{c}\mathbf{b}^{\mathbf{b}} \\
\text { Ranges }^{\text {NRC }}\end{array} \\
\text { Values }^{\mathrm{c}}\end{array}$ \\
\hline Bush Bean, leaves & 0.40 & 2.82 & 1.19 & 4 & \\
Bush Bean, stem & 0.793 & 2.32 & 1.56 & 2 & \\
Corn, leaves & 0.209 & 0.563 & 0.386 & 2 & $\ldots$ \\
Corn, stem & 0.127 & 0.269 & 0.198 & 2 & \\
Pine Trees, leaves & 0.018 & 0.61 & 0.31 & 2 & $0.01-1$ \\
\hline
\end{tabular}

a $\quad \mathrm{N}=$ Number of Values

b Literature Sources: Till and Meyer 1983

c NRC values - Factors for fresh-weight vegetation provided by the Nuclear Regulatory Commission (NRC 1977, Table E-1) for use in calculating dose in the absence of site-specific data. 


\section{TRANSURANICS}

\section{Introduction}

The transuranics, plutonium, americium, and curium are man-made elements and have no stable isotopes. The chemistry of these elements is generally complex because they assume different valence states, depending on environmental conditions. These elements have no known biological function.

Plutonium was produced at SRS during operations of five production reactors and released in small quantities during the processing of fuel and targets in chemical separations facilities. Approximately $13 \mathrm{Ci}$ have been released to onsite streams and seepage basins, while approximately 4 $\mathrm{Ci}$ have been released to the atmosphere (Cummins et al. 1991a). Virtually all releases have occurred in the separations facilities located in $\mathrm{F}$ and $\mathrm{H}$ Areas (Carlton, et al. 1992b). Plutonium is a small contributor to the maximum individual dose from both liquid (8\%) and atmospheric (5\%) releases (Arnett et al: 1993). Plutonium-238 and plutonium-239 are the primary plutonium radioisotopes that are considered in this report with half-lives of 87.4 years and 24,000 years, respectively.

Other transuranics that have been released at SRS and will be considered in this report include americium-241 and curium-244. Approximately $0.28 \mathrm{Ci}$ of americium-241 and $0.82 \mathrm{Ci}$ of curium- 244 have been released to streams and seepage basins, and approximately $0.0052 \mathrm{Ci}$ of americium-241 and $0.091 \mathrm{Ci}$ curium-244 have been released to the atmosphere. These radionuclides are negligible contributors to dose ( $<1 \%$ ) (Arnett et al. 1993). Americium241 has a half life of 458 years and curium-244 has a half life of 17.6 years.

\section{Aquatic Bioconcentration Factors}

Whicker et al. (1989) studied the distribution of various radionuclides, including transuranics, in Pond B. Bioconcentration factors were calculated for americium-241, curium-244, plutonium-238, and plutonium-239. In all cases, the maximum bioconcentration factors were found in macroinvertebrate larvae. The bioconcentration factors reported by Whicker et al. 1989 are higher than those factors reported in the literature (Table 6-1).

Transuranic elements are known to be fixed by clay minerals and complexed by organic matter which may decrease their availability. Zooplankton and benthic insect larvae have high surface to volume ratios. This allows their surfaces as well as their guts to carry sediment and sestonic particles, which adsorb transuranic particles; thus resulting in higher bioconcentration factors. (Whicker et al. 1989).

Aquatic macrophytes also showed high concentration factors, which could have resulted from sediment adsorbing to the leaves which were not cleansed of all periphyton prior to processing (Whicker et al. 1989). Vertebrate bone and muscle, which are not affected by transuranic adsorption, had lower bioconcentration factors. The lower bioconcentration factors for waterfowl may be the result of their short residence time on Pond $B$.

Plutonium-238 ranged from 2,600 in fish muscle (piscivores) to 840,000 in macroinvertebrate larvae. Plutonium239 ranged from 850 in waterfowl muscle to 190,000 in macroinvertebrate larvae. Americium-241 values ranged from 650 in waterfowl muscle to 240,000 in macroinvertebrate larvae; curium-244 values ranged from 84 in the water shield (floating vascular plant) to 19,000 in macroinvertebrate larvae. 
Table 6-1: Bioconcentration Factors for Transuranics in Aquatic Ecosystems (Cummins, 1994).

\begin{tabular}{|c|c|c|c|c|c|c|}
\hline \multirow[b]{2}{*}{ Plutonium-238 } & \multicolumn{4}{|c|}{ SRS Calculated Values } & \multicolumn{2}{|c|}{ Non-SRS Values } \\
\hline & Minimum & Maximum & $\operatorname{Mean}^{\mathrm{a}}$ & $N^{b}$ & $\begin{array}{l}\text { Literature } \\
\text { Ranges }\end{array}$ & $\begin{array}{c}\text { NRC } \\
\text { Values }\end{array}$ \\
\hline Fish muscle (Piscivores) & & 2,600 & & $I$ & 25 & 3.5 \\
\hline $\begin{array}{l}\text { Fish muscle (Benthic } \\
\text { invertebrate and fish } \\
\text { feeders) }\end{array}$ & & 12,000 & & 1 & & \\
\hline Fish bone (Piscivores) & & 17,000 & & 1 & & \\
\hline Macroinvertebrates, larvae & & 840,000 & & 1 & & \\
\hline Macrophyte (rooted vascular) & 17,000 & 78,000 & 45,250 & 4 & & \\
\hline $\begin{array}{l}\text { Macrophyte (Floating } \\
\text { vascular) }\end{array}$ & & 91,000 & & 1 & & \\
\hline Turtles, muscle & & 14,000 & & 1 & & \\
\hline Turtles, shell \& bone & & 19,000 & & 1 & & \\
\hline Waterfowl, muscle & & 3,800 & & 1 & & \\
\hline Waterfowl, bone & & 18,000 & & 1 & & \\
\hline Plutonium-239 & Minimum & Maximum & Mean $^{2}$ & $\mathrm{~N}^{b}$ & $\begin{array}{l}\text { Literature } \\
\text { Ranges }^{c}\end{array}$ & $\begin{array}{c}\text { NRC } \\
\text { Values }^{d}\end{array}$ \\
\hline Fish muscle (Piscivores) & & 5,600 & & 1 & $0.4-25$ & 3.5 \\
\hline Macroinvertebrates, larvae & & 190,000 & & 1 & $587-30,000$ & \\
\hline Macrophyte (rooted vascular) & 6,600 & 52,000 & 26,150 & 4 & $230-9,000$ & \\
\hline $\begin{array}{l}\text { Macrophyte (Floating } \\
\text { vascular) }\end{array}$ & & 100,000 & & & & \\
\hline Turtle, muscle & & 6,600 & & 1 & & \\
\hline Waterfowl, muscle & & 850 & & 1 & & \\
\hline Zooplankton & & 23,000 & & 1 & $122-5,600$ & \\
\hline
\end{tabular}

a Mean not calculated for fewer than four data points

b $\quad \mathrm{N}=$ Number of values

c Literature Sources: Blaylock (1982), Till and Meyer (1983), Vanderplog et al. (1975), Whicker et al. (1989), Eyman and Trabalka (1980)

d NRC values - Factors provided by the Nuclear Regulatory Commission (NRC 1977, Table A-1) for freshwater fish and invertebrates for use in calculating dose in the absence of site-specific data 
Table 6-1: Bioconcentration Factors for Transuranics in Aquatic Ecosystems (Cummins, 1994) (cont'd)

\begin{tabular}{|c|c|c|c|c|c|c|}
\hline \multirow{2}{*}{ Americium-241 } & \multicolumn{4}{|c|}{ SRS Calculated Values } & \multicolumn{2}{|c|}{ Non-SRS Values } \\
\hline & Minimum & Maximum & Mean $^{2}$ & $\mathbf{N}^{b}$ & $\begin{array}{l}\text { Literature } \\
\text { Ranges }\end{array}$ & $\begin{array}{c}\text { NRC } \\
\text { Values }\end{array}$ \\
\hline Fish muscle (Piscivores) & & 2,500 & & 1 & 50 & 25 \\
\hline $\begin{array}{l}\text { Fish bone (Benthic } \\
\text { invertebrate and fish } \\
\text { feeders) }\end{array}$ & & 4,200 & & 1 & & \\
\hline Macroinvertebrate, larvae & 78,000 & 240,000 & & & & \\
\hline Macrophyte (rooted vascular) & 1,400 & 21,000 & & 3 & & \\
\hline $\begin{array}{l}\text { Macrophyte (Floating } \\
\text { vascular) }\end{array}$ & & 75,000 & & 1 & & \\
\hline Turtle, muscle & & 5,600 & & 1 & & \\
\hline Waterfowl, muscle & & 650 & & 1 & & \\
\hline Curium-244 & Minimum & Maximum & $\operatorname{Mean}^{\mathrm{a}}$ & $N^{b}$ & $\begin{array}{c}\text { Literature } \\
\text { Ranges }^{c}\end{array}$ & $\begin{array}{c}\text { NRC } \\
\text { Values }\end{array}$ \\
\hline Fish muscle (Piscivores) & & 410 & & $T$ & 50 & 25 \\
\hline $\begin{array}{l}\text { Fish muscle (Benthic } \\
\text { invertebrate and fish } \\
\text { feeders) }\end{array}$ & & 91 & & 1 & & \\
\hline Fish bone (Piscivores) & & 1,400 & & 1 & & \\
\hline Macroinvertebrate, larvae & 1,400 & 19,000 & & 2 & & 25 \\
\hline Macrophyte (rooted vascular) & & 780 & & 1 & & \\
\hline $\begin{array}{l}\text { Macrophyte (Floating } \\
\text { vascular) }\end{array}$ & 84 & 370 & & 3 & & \\
\hline Turtle, muscle & & 110 & & 1 & & \\
\hline Turtle, shell \& bone & & 190 & & 1 & & \\
\hline Waterfowl, muscle & & 110 & & 1 & & \\
\hline \multicolumn{7}{|c|}{$\begin{array}{l}\text { a } \\
\text { b }\end{array}$} \\
\hline \multicolumn{7}{|c|}{$\begin{array}{l}\text { c Literature Sources: Blaylock (1982), Till and Meyer (1983), Vanderplog et al. (1975), Whicker et al. } \\
\text { (1989), Eyman and Trabalka (1980) }\end{array}$} \\
\hline \multicolumn{7}{|c|}{$\begin{array}{l}\text { dRC values - Factors provided by the Nuclear Regulatory Commission (NRC 1977, Table A-1) for fresh- } \\
\text { water fish and invertebrates for use in calculating dose in the absence of site-specific data }\end{array}$} \\
\hline
\end{tabular}




\section{Terrestrial and Wetland Bioconcentration Factors}

Plant uptake of transuranic radionuclides is influenced by soil $\mathrm{pH}$, Eh (oxidation state), cation exchange capacity, texture, organic matter, fertilizers, and other treatments. Transuranic elements are fixed by clay minerals and complexed by organic matter which may affect their availability. Higher pH generally decreases metal uptake, whereas chelate additions usually increase uptake (McLeod et al. 1981).

Plant properties also influence uptake of transuranic nuclides. Plant roots excrete protons, organic and amino acids, chelators, and other substances, all of which have an effect on the uptake and translocation of many metals, including transuranics. The depth of rooting is another factor that affects plant uptake. Nuclides in lower horizons of soil may be mobilized by deep roots, but not mobilized by shallow roots. Decomposition of plant residues influences both uptake and recycling (Adriano et al. 1980b).

The sources of elements and particle size also affects availability of transuranics. Small particles are more subject to weathering and they release nuclides faster than do large particles. Oxides are less available than other forms. The transuranic elements themselves differ in phytoavailability ( $\mathrm{Pu}<\mathrm{Am}<\mathrm{Cm}<\mathrm{Np}$ ) (Adriano et al. 1980b).

Although root uptake is generally small, transuranic elements that have been incorporated into plant tissues may be chemically bound to proteins, lipids, and other organic components. Very little is translocated to the grain or edible portion (Adriano et al. 1981b).

Kirkham et al. (1979) studied total plutonium concentrations in white-tailed deer from the Savannah River site. Bioconcentration factors were calculated based on honeysuckle to deer uptake. The concentration factors ranged from 0.014 in the muscle to 0.175 in the bone. Concentration factors were also calculated based on soil to deer uptake. These factors ranged from 0.001 in the muscle to 0.015 in the bone.

The maximum bioconcentration factor for plutonium239,240 was in rice $(0.025)$. A bioconcentration factor of 0.17 was calculated for plutonium-239 in corn.

Site-specific bioconcentration factors for americium-241 ranged from 0.03 to 0.12 for bahia grass and from 0.00014 to 0.00025 in pine trees. These values are comparable to literature values (Table 6-2).

Maximum bioconcentration factors for curium-244 in agricultural crops ranged from 0.0031 in corn to 0.028 in soybean. In native vegetation, maximum concentration factors ranged from 0.0021 in tree bark to 0.0036 in tree wood. 
Table 6-2: Bioconcentration Factors for Transuranics in Terrestrial and Wetland Ecosystems (Cummins, 1994).

\begin{tabular}{|c|c|c|c|c|c|c|}
\hline & & Calculated V & & & Non-SR & alues \\
\hline Total Plutonium & Minimum & Maximum & Mean $^{\mathbf{a}}$ & $\mathbf{N}^{\mathbf{b}}$ & $\begin{array}{c}\text { Literature } \\
\text { Ranges }\end{array}$ & $\begin{array}{l}\text { NRC } \\
\text { Values }\end{array}$ \\
\hline Corn, grain & & 0.00006 & & 1 & & \\
\hline Corn, leaves & & 0.0006 & & 1 & & \\
\hline Soybeans & & 0.003 & & 1 & & \\
\hline Wheat & & 0.002 & & 1 & $3.8 \mathrm{E}-08-0.04$ & 0.00025 \\
\hline White-tailed deer, bone & 0.015 & 0.175 & 0.095 & 2 & $0.023-0.350$ & \\
\hline White-tailed deer, liver & 0.013 & 0.148 & 0.081 & 2 & $0.035-0.533$ & \\
\hline White-tailed deer, lungs & 0.006 & 0.073 & 0.040 & 2 & $0.033-0.50$ & \\
\hline White-tailed deer, muscle & 0.001 & 0.0014 & 0.0012 & 2 & $0.01-0.15$ & \\
\hline Plutonium-238 & Minimum & Maximum & Mean $^{a}$ & $\mathbf{N}^{b}$ & $\begin{array}{c}\text { Literature } \\
\text { Ranges }\end{array}$ & $\begin{array}{c}\text { NRC } \\
\text { Values }^{d}\end{array}$ \\
\hline Bahia Grass & 0.00006 & 0.0056 & 0.0013 & 5 & & \\
\hline Clover & 0.00015 & 0.067 & 0.013 & 5 & $1 E-05-1 E-04$ & \\
\hline Corn, leaves & 0.00017 & 0.019 & 0.0042 & 7 & 0.01 & \\
\hline Com, stalk & 0.00021 & 0.45 & & 3 & $0.01-10$ & \\
\hline Pine Trees, leaves & 0.00015 & 0.0047 & & 2 & $0.006-0.1$ & \\
\hline Rice, foliage & 0.00026 & 0.00049 & 0.00033 & 4 & & \\
\hline Rice, grain & 0.00009 & 0.00036 & 0.00021 & 4 & & \\
\hline Soybeans, beans & 0.00052 & 0.26 & & 3 & & \\
\hline Soybean, stems & 0.00068 & 0.16 & & 2 & & \\
\hline $\begin{array}{l}\text { Tree wood (maple, sweet- } \\
\text { gum, and poplar) }\end{array}$ & . & 0.000033 & & 1 & & \\
\hline $\begin{array}{l}\text { Tree bark (maple, sweet- } \\
\text { gum, and poplar) }\end{array}$ & & 0.00027 & & 1 & & \\
\hline $\begin{array}{l}\text { Tree leaf (maple, sweetgum, } \\
\text { and poplar) }\end{array}$ & & 0.00030 & & 1 & & \\
\hline Wheat, grain & 0.00037 & 0.035 & & 3 & $1 \mathrm{E}-08-0.001$ & \\
\hline Wheat, stems & 0.00024 & 0.0014 & 0.0032 & 5 & & \\
\hline $\begin{array}{ll}\text { a } & \text { Mean not calculated for } \\
\text { b } & \mathrm{N}=\text { Number of Values } \\
\text { c } & \text { Literature Source: Adam } \\
& (1982) \text {, Romney et al. (1 } \\
\text { d } & \text { NRC values - Factors fo } \\
& \text { (NRC 1977, Table E-1) } \mathrm{f}\end{array}$ & $\begin{array}{l}\text { er than four } \\
\text { tal. (1975), } \\
\text { ), Shulz et } \\
\text { esh-weight } \\
\text { Ise in calcul }\end{array}$ & $\begin{array}{l}\text { points } \\
\text { htrey and Th } \\
\text { 76), and Wal } \\
\text { tion providec } \\
\text { dose in the at }\end{array}$ & $\begin{array}{l}\text { 1985), K } \\
976) \\
\text { e Nuclea } \\
\text { of site-s }\end{array}$ & 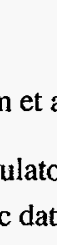 & $\begin{array}{l}\text { (1979), } \mathrm{Ng} \\
\text { Commission }\end{array}$ & \\
\hline
\end{tabular}


Table 6-2:

Bioconcentration Factors for Transuranics in Terrestrial and Wetland Ecosystems

(Cummins, 1994)(cont'd)

\begin{tabular}{|c|c|c|c|c|c|c|}
\hline \multirow{3}{*}{ Plutonium-239 } & \multicolumn{4}{|c|}{ SRS Calculated Values } & \multicolumn{2}{|c|}{ Non-SRS Values } \\
\hline & & & & & Literature & NRC \\
\hline & Minimum & Maximum & Mean $^{a}$ & $N^{b}$ & Ranges $^{c}$ & Values $^{d}$ \\
\hline Corn, stalk & 0.072 & 0.017 & & $\overline{2}$ & & \\
\hline Plutonium-239,240 & Minimum & Maximum & $\operatorname{Mean}^{\mathrm{a}}$ & $\mathbf{N}^{\mathbf{b}}$ & $\begin{array}{c}\text { Literature } \\
\text { Ranges }^{c}\end{array}$ & $\begin{array}{c}\text { NRC } \\
\text { Values }\end{array}$ \\
\hline Bahia Grass & 0.000089 & 0.0044 & & 3 & & \\
\hline Clover & 0.00014 & 0.02 & & 3 & & \\
\hline Corn, leaves & 0.00021 & 0.014 & & 3 & & \\
\hline Corn, stalk & 0.0016 & 0.017 & & 3 & & \\
\hline Pine Trees, leaves & 0.00012 & 0.0073 & & 2 & $0.006-0.1$ & \\
\hline Rice, foliage & 0.0075 & 0.025 & & 2 & & \\
\hline Rice, grain & 0.0079 & 0.015 & & 2 & & \\
\hline Soybean, bean & 0.00056 & 0.074 & & 3 & & \\
\hline Soybean, stem & 0.00072 & 0.054 & & 3 & & \\
\hline Wheat, grain & 0.00042 & 0.029 & & 3 & & \\
\hline Wheat, vegetation & 0.00018 & 0.013 & & 3 & & \\
\hline
\end{tabular}

a Mean not calculated for fewer than four data points

b $\mathrm{N}=$ Number of Values

c Literature Source: Adams et al. (1975), Coughtrey and Thorne (1985), Ng (1982), Romney et al. (1970), Shulz et al (1976), and Wallace (1976)

d NRC values - Factors for fresh-weight vegetation provided by the Nuclear Regulatory Commission (NRC 1977, Table E-1) for use in calculating dose in the absence of site-specific data 
Table 6-2: Bioconcentration Factors for Transuranics in Terrestrial and Wetland Ecosystems (Cummins, 1994) (cont'd)

SRS CaIculated Values

Non-SRS Values

\begin{tabular}{|c|c|c|c|c|c|c|}
\hline \multirow[b]{2}{*}{ Americium-241 } & & \multirow{2}{*}{$\begin{array}{c}\text { Literature } \\
\text { Ranges }\end{array}$} & \multirow{2}{*}{$\begin{array}{c}\text { NRC } \\
\text { Values }^{d}\end{array}$} \\
\hline & Minimum & Maximum & $\operatorname{Mean}^{\mathrm{a}}$ & $N^{b}$ & & \\
\hline$\overline{\text { Bahia Grass }}$ & 0.03 & 0.12 & 0.067 & 6 & $2.3 \mathrm{E}-7-0.005$ & 0.00025 \\
\hline Pine Trees, leaves & 0.00014 & 0.00025 & & 2 & $0.0001-0.1$ & \\
\hline Curium-242,244 & Minimum & Maximum & $\operatorname{Mean}^{a}$ & $N^{b}$ & $\begin{array}{c}\text { Literature } \\
\text { Ranges }\end{array}$ & $\begin{array}{c}\text { NRC } \\
\text { Values }\end{array}$ \\
\hline Pine Trees, leaves & 0.0052 & 0.021 & 0.013 & 2 & $1 \mathrm{E}-06-1.7$ & \\
\hline Curium-244 & Minimum & Maximum & Mean $^{a}$ & $\mathbf{N}^{b}$ & $\begin{array}{c}\text { Literature } \\
\text { Ranges }\end{array}$ & $\begin{array}{c}\text { NRC } \\
\text { Values }\end{array}$ \\
\hline Bahia Grass & 0.0075 & 0.0115 & & 3 & & \\
\hline Clover & 0.0391 & 0.0499 & & 3 & & \\
\hline Corn, ear & & 0.0031 & & 1 & & \\
\hline Corn, leaves & 0.011 & 0.0244 & & 3 & & \\
\hline Corn, stalk & & 0.0097 & & 1 & & \\
\hline Rice, foliage & 0.0020 & 0.0023 & 0.0022 & 4 & & \\
\hline Rice, grain & 0.0013 & 0.0045 & 0.0024 & 4 & & \\
\hline Soybean, bean & & 0.0045 & & 1 & & \\
\hline Soybean, stem & 0.013 & 0.028 & & 2 & & \\
\hline $\begin{array}{l}\text { Tree wood (maple, sweet- } \\
\text { gum, and poplar) }\end{array}$ & & 0.0036 & & 1 & & \\
\hline $\begin{array}{l}\text { Tree bark (maple, sweet- } \\
\text { gum, and poplar) }\end{array}$ & & 0.0021 & & 1 & & \\
\hline $\begin{array}{l}\text { Tree leaf (maple, sweetgum, } \\
\text { and poplar) }\end{array}$ & & 0.0075 & & 1 & & \\
\hline Wheat, stem & 0.0035 & 0.0069 & & 2 & & \\
\hline Wheat, grain & & 0.0033 & & 1 & & \\
\hline
\end{tabular}

a Mean not calculated for fewer than four data points

b $\quad \mathrm{N}=$ Number of Values

c Literature Source: Adams et al. (1975), Coughtrey and Thorne (1985), $\mathrm{Ng}$ (1982), Romney et al. (1970), Shulz et al (1976), and Wallace (1976)

d NRC values - Factors for fresh-weight vegetation provided by the Nuclear Regulatory Commission

(NRC 1977, Table E-1) for use in calculating dose in the absence of site-specific data 


\section{TRITIUM}

\section{Introduction}

Tritium has been released to the environment as a result of many operations at the Savannah River Site. Releases have occurred from reactor operations, recovery of transuranic elements, recovery of tritium, laboratory research, and heavy water rework. Over 24 million curies of tritium have been released to the atmosphere, and approximately 1.5 million curies of tritium have been released to seepage basins and streams (Cummins et al. 1991a). Tritium contributes approximately $90 \%$ of the committed dose to the maximum individual from atmospheric releases and approximately $35 \%$ from liquid releases (Arnett et al. 1993). Tritium has a half-life of 12.4 years.

Tritium is an isotope of hydrogen and behaves similarly in the environment to the other isotopes of hydrogen, protium and deuterium. Hydrogen is the most abundant element on earth in terms of the number of atoms. It forms an enormous number of compounds, including its association with carbon in almost all organic compounds. In terms of abundance and mobility, water is the most important compound of hydrogen (Murphy 1993).

\section{Aquatic Bioconcentration Factors}

Tritium enters aquatic systems in the form of tritiated water (HTO). Tritiated water behaves like $\mathrm{HOH}$ and mixes rapidly with the tissue water of aquatic organisms. The observation that the ratio of tritium to hydrogen in organisms is similar to that in their environment suggests that there is no biomagnification up the food chain (Murphy 1993).

Vanderplog et al. (1975) concluded that the bioconcentration factor for tritium was approximately one. The biological half-life of tritium in fish is $<1$ day; thus the concentration of tritium in fish will follow closely the concentration of tritium in the water to which the fish have been exposed to in the past day or less. A tritium uptake study by Eaton and Murphy (1992) indicated that the tritium activity of the tissue water of fish was approximately equal to the activity of the source water.

Organic tritium is also present in aquatic systems. The sources of organic tritium are from the incorporation of tri- tiated water by photosynthesis (algae and other aquatic plants) and from the uptake of detritus of either terrestrial or aquatic origin. The transfer of organic tritium through the food chain from photosynthetic or detritus inputs depends on the nature of the organic material consumed (Murphy 1993). However, once incorporated, the metabolic turnover of organic tritium in fish are on the order of months to years (Eaton and Murphy 1992). A tritium uptake study by Eaton and Murphy (1992) determined that the tritium activity of the organic matter of the fish was approximately equal to the activity of the water measured in the previous year.

\section{Terrestrial and Wetland Bioconcentration Factors}

Tritium can enter terrestrial vegetation by two mechanisms-vapor exchange with the atmosphere and root uptake of soil water. Atmospheric tritium oxide reaches equilibrium with vegetation in matter of hours and takes place through the stoma on the leaf surface. Uptake of soil water occurs through the roots and is influenced by the capillary tension holding water in the soil, the root density, and the root depth (Murphy 1993). Equilibrium is reached in a matter of days. Once in the vegetation, tritium has a high turnover rate, and concentrations in the vegetation will lie between the concentration of the different sources of water in the leaves.

There have been no measurements of tritium in soil water; thus, no bioconcentration factors have been calculated for vegetation/soil. However, it has been determined that tritium activity in the soil is similar to that in the rainwater (Sweet and Murphy 1984). There have been bioconcentration factors determined for vegetation exposure to atmospheric tritium oxide. Murphy (1984) calculated a vegetation/air ratio of 0.77 . Hamby and Bauer (1993) calculated a vegetation/air ratio of 0.54 .

Tritium concentrations in animals are similar to that in vegetation in that the concentration results from tritium transport to and from the animal through numerous paths (Robertson 1973 and Yousef 1973). However, the two primary sources of exposure for animals are from drinking 
water and from food. The water turnover time for most species is less than 10 days, which suggests that most animal species, like vegetation, will respond to day to day changes of tritium in their environment. However, unlike vegetation, animals are mobile and will contain water that is averaged over the area in which they range (Murphy 1993). There have been no site-specific studies performed to calculate tritium bioconcentration factors for animals. 


\section{REFERENCES}

Adams, W.H., J.R. Buchholz, C.W. Christenson, G.L. Johnson, and E.B. Fowler, 1975, Study of Pu, Am, and U in Environmental Matrices, ERDA Report LA-5561, Los Alamos Scientific Laboratory, NTIS.

Adriano, D.C., M. Delaney, and D. Paine, 1977, "Availability of Cobalt-60 to Corn and Bean Seedlings as Influenced by Soil Type, Lime, and DTPA”, Communication In Soil Science and Plant Analysis, Vol. 8, No. 8, pp. 615-628.

Adriano, D.C., J.C. Corey, and R.C. Dahlman, 1980a, "Plutonium Contents of Field Crops in the Southeastern United States", in Transuranic Elements in the Environment, W.C. Hanson, (ed.), DOE/TIC-22800.

Adriano, D.C., A. Wallace, and E.M. Romney, 1980b, "Uptake Of Transuranic Nuclides From Soil by Plants Grown Under Controlled Environmental Conditions", in Transuranic Elements in the Environment, W. C. Hanson, (ed.) DOE/TIC22800, pp. 336-360.

Adriano, D.C., K.W. McLeod, and T.G. Ciravolo, July 1981a, "Curium Uptake by Crops from Naturally-Weathered Contaminated Soil", Health Physics, Vol. 41, pp. 69-75.

Adriano, D.C., K.W. McLeod, and T.G. Ciravolo, July 1981b, "Plutonium, Curium, and Other Radionuclide Uptake by the Rice Plant from a Naturally Weathered, Contaminated Soil", Soil Science, Vol. 132, No. 1, pp. 83-88.

Adriano, D.C., K.W. McLeod, and T.G. Ciravolo, 1984, "Long-Term Root Uptake of Radiocesium by Several Crops", Journal of Plant Nutrition, Vol. 7, No. 10, pp. 1415-1432.

Adriano, D.C., K.W. McLeod, and T.G. Ciravolo, May 1986, "Long-Term Availability of Cm and Pu to Crop Plants", Health Physics, Vol. 50, No. 5, pp 647-651.

Anderson, G.E., J.B. Gentry, and M.H. Smith, 1973, "Relationships Between Levels of Radiocesium in Dominant Plants and Arthropods in a Contaminated Streambed Community", Oikos, Vol. 24, pp. 165-170.

Arnett, M.W., L.K. Karapatakis, and A.R. Mamety, (editors), 1993, Saivannah River Site Environmental Report for 1992, WSRC-TR-93-075, Westinghouse Savannah River Company, Aiken, SC.

Blaylock, B.G., 1982, "Radionuclide Data Bases Available for Bioaccumulation Factors for Freshwater Biota", Nuclear Safety, Vol. 23, No. 4, pp. 427-438.

Briese, L.A. Garten, Jr., and C.T. Sharitz, R.R., 1975, "Distribution of Radiocesium in Vegetation Along a Contaminated Stream", in Mineral Cycling in Southeastern Ecosystems, F. G. Howell, J. B. Gentry, and M. H. Smith (eds.). ERDA Symposium Series. (CONF-740513).

Brisbin, I.L, M.A. Staton, J.E. Pinder, III, and R.A. Gieger, June 13,1974, "Radiocesium Concentrations of Snakes from Contaminated and Non-Contaminated Habitats of the AEC Savannah River Plant", Copeia, No. 2, pp. 501-506.

Brisbin, I.L. and M.H. Smith, 1975, "Radiocesium Concentrations in Whole-Body Homogenates and Several Body Compartments of Naturally Contaminated White-Tailed Deer", In: Mineral Cycling in Southeastern Ecosystems, F.G. Howell, J.B. Gentry, and M.H. Smith (eds.), ERDA Symposium Series, (CONF-740513).

Carlton, W.H., L.R. Bauer, A.G. Evans, L.A. Geary, C.E. Murphy, Jr., J.E. Pinder, and R.N. Strom, 1992a, Cesium in the Savannah River Site Environment (U), WSRC-RP-92250, Westinghouse Savannah River Company, Aiken, SC. 
Carlton, W.H., A.G. Evans, L.A. Geary, C.E. Murphy, Jr., J.E. Pinder, and R.N. Strom, 1992b, Assessment of Strontium in the Savannah River Site Environment (U), WSRC-RP-92-984, Westinghouse Savannah River Company, Aiken, SC.

Carlton, W.H., A.G. Evans, L.A. Geary, C.E. Murphy, Jr., and R.N. Strom, 1992c, Assessment of Plutonium in the Savannah River Site Environment (U), WSRC-RP-92-879, Westinghouse Savannah River Company, Aiken, SC.

Clark, J.U. and V.A. McFarland, 1991, Assessing Bioaccumulation in Aquatic Organisms Exposed to Contaminated Sediments, Miscellaneous Paper D-91-2, Environmental Laboratory, Waterways Experiment Station, Vicksburg, MS.

Corey, J.C. Boni, A.L. Watts, J.R. Adriano, D.C. McLeod, and K.W. Pinder, III J.E., 1983, "The Relative Importance of Uptake and Surface Adherence in Determining the Radionuclide Contents of Subterranean Crops", Health Physics, Vol. 44, No. 1, pp. 1928.

Coughtrey, P.J. and M.C. Thorne, 1985, Radionuclide Distribution and Transport in Terrestrial and Aquatic Ecosystems, A.A. Balkema Publ., Boston, MA, 6 Vols.

Cowardin, L.M., V. Carter, F.S. Golet, and E.T. LaRoe, 1979, Classification of Wetlands and Deepwater Habitats of the United States, Fish and Wildlife Service, U.S. Department of the Interior, PWS/OBS-79/31, 103pp.

Croom, J.M., 1978, Sandhills-Turkey Oak (Quercus laevis) Ecosystem: Community Analysis and a Model of Radiocesium Cycling, A dissertation submitted to the Faculty of the Graduate School of Emory University.

Crossley, D.A., Jr., 1963, "Movement and Accumulation of Radiostrontium and Radiocesium in Insects", In: Radioecology: Proceedings of the First National Symposium on Radioecology, Reinhold, NY, V. Schultz and A. W. Klement, Jr. (eds), pp. 427-420.

Crossley, D.A., Jr., 1969, “Comparative Movement of ${ }^{106} \mathrm{Ru},{ }^{60} \mathrm{Co}$, and ${ }^{137} \mathrm{Cs}$ in Arthropod Food Chains", In: Radioecology: Proceedings of the Second National Symposium, USAEC Report CONF-670503, D.J. Nelson and F.C. Evans (eds), pp. 687-695.

Cummins, C.L., 1994, Radiological Biococentration Factors for Aquatic, Terrestrial, and Wetland Ecosystems at the Savannah River Site $(U)$, WSRC-TR-94-0391, Westinghouse Savannah River Company, Aiken, SC.

Cummins, C.L., C.S. Hetrick, and D.K. Martin, 1991a, Radioactive Releases at the Savannah River Site (1954 - 1989) (U), WSRC-RP-91-684, Westinghouse Savannah River Company, Aiken, SC.

Cummins, C.L, D.K. Martin, and J.L. Todd, 1991b, Savannah River Site Environmental Report for 1990, WSRC-IM-91028, Westinghouse Savannah River Company, Aiken, SC.

Dahlman, R.C., C.W. Francis, and T. Tamura, 1975, "Radiocesium Cycling in Vegetation and Soil", In: Mineral Cycling in Southeastern Ecosystems, F.G. Howell, J.B. Gentry, and M.H. Smith (eds.), ERDA Symposium Series, (CONF-740513).

Dahlman, R.C. and K.W. McLeod, 1977; "Foliar and Root Pathways of Plutonium Contamination of Vegetation", In: Transuranics in Natural Environments, M.G. White and P.B. Dunaway (eds.).

Eaton, D. and C.E. Murphy, Jr., 1992, Tritium Uptake by Fish in a Small Stream, WSRC-TR-92-193, Rev. 1, Westinghouse Savannah River Company, Aiken, SC.

Eisenbud, M., 1973, Environmental Radioactivity, Second Edition, Academic Press, New York, NY.

Eisler, Ronald, 1994, Radiation Hazards to Fish, Wildlife, and Invertebrates: A Synoptic Review, U.S. Department of the Interior, National Biological Service, Biological Report 26, Contaminant Hazard Reviews Report 29, Washington, D.C. 
Evans, E.J. and A.J. Decker, 1968, “Comparative Cs-137 Content of Agricultural Crops Grown in a Contaminated Soil”, Canadian Journal of Plant Science, Vol. 48, pp. 183-188.

Eyman, L.D. and T. R. Trabalka, 1980, "Patterns of Transuranic Uptake by Aquatic Organisms: Consequences and Implications" In: Transuranic Elements in the Environment, W.C. Hanson (ed), DOE/TIC-22800, U.S. Department of Energy, pp. 612-624.

Garten, Jr., C.T., L.A. Briese, R.R. Sharitz, and J.B. Gentry, 1975a, "Seasonal Variation in Radiocesium Concentrations in Three Tree Species", In: Mineral Cycling in Southeastern Ecosystems, F.G. Howell, J. B. Gentry, and M. H. Smith (eds.)., ERDA Symposium Series. (CONF-7405 13), pp. 498-508.

Garten, Jr., C.T., L.A. Briese, R.A. Geiger, R.R. Sharitz, and M.H. Smith, 1975b, "Radiocesium Levels in Vegetation Colonizing a Contaminated Floodplain", In: Mineral Cycling in Southeastern Ecosystems, J F. G. Howell, J. B. Gentry, and M.H. Smith (eds.), ERDA Symposium Series (CONF-740513).

Garten, Jr., C.T. and D. Paine, 1977, “A Multivariate Analysis of Factors Affecting Radiocesium Uptake by Sagittaria latifolia in Coastal Plain Environments", Journal of Environmental Quality, Vol. 6, No. 1, pp. 78-82.

Gay, D.D., 1982, Burial Ground Uptake Studies- Surface Contamination, DPST-82-1072, Technical Division, Savannah River Laboratory, E.I. Du Pont de Nemours \& Co., Aiken, SC.

Giesey, J.P., Jr., and Paine, D., "Effect of Naturally Occurring Organics on Plutonium-237 Uptake by Algae and Bacteria", In: Transuranics in the Natural Environment, M.G. White and P.B. Dunaway (eds), NVO-178, Las Vegas, NV, pp. 531543.

Gladden, J.B., 1979, Radiocesium Exchange Among Components of a Coastal Plain Bottomland Stream Ecosystem, An abstract of a dissertation submitted to the faculty of the Graduate School of Emery University.

Godfrey, R.K. and J.W. Wooten, 1979, Aquatic and Wetland Plants of the Southeastern United States: Monocotyledons, University of Georgia Press, Athens, GA, 712 pp.

Godfrey, R.K. and J.W. Wooten, 1981, Aquatic and Wetland Plants of the Southeastern United States: Dicotyledons, University of Georgia Press, Athens, GA, 933 pp.

Hamby, D.M. and L.R. Bauer, 1993, The Vegetation-to-Air Concentration Ratio in a Specific Activity Tritium Model, WSRC-MS-93-223, Westinghouse Savannah River Company, Aiken, SC.

Hardy, E.P. and B.G. Bennett, 1977, Radionuclide Uptake by Cultivated Crops, HASL321, pp. I-19 through I-37.

Harvey, R.S., 1964, "Uptake of Radionuclides by Freshwater Algae and Fish", Heatth Physics, Vol. 10, pp. $243-247$.

Harvey, R.S., 1969, "Uptake and Loss of Radionuclides by the Freshwater Clam Lampsilis Radiata (Gmel.)”, Health Physics, Vol. 17, pp. 149-154.

Haselow, L.A., May 1991, The Relationship of Radiocesium and Potassium in the Nutritional Ecology of White-Tailed Deer from the Savannah River Site, A thesis to the Faculty of Purdue University.

Hay, J.D., 1977, A Comparative Analysis of Cs-137 Dynamics in Two Floodplain Forests Along a Southeastern Coastal Plain Stream, An abstract of a dissertation submitted to the Faculty of the Graduate School of Emory University.

Hersloff, L.W. and J.C. Corey, 1978, "Uptake of Three Isotopes of Plutonium From Soil by Sweet Corn Grown in a Growth Chamber", Environmental Chemistry and Cycling Processes, D.C. Adriano and I.L. Brisbin, Jr. (eds), DOE Symposium Series (CONF760429). 
Hinton, T.G., 1996, Unpublished data collected from Par Pond, L-Lake, Pond C, and Pond 5 between 1991 and 1996, Savannah River Ecology Laboratory, University of Georgia, Aiken, SC.

Hoyt, G. D. and D.C. Adriano, 1979, "Americium-241 Uptake by Bahiagrass as Influenced by Soil Type, Lime, and Organic Matter", Journal of Environmental Quality, Vol 8, No. 3, pp. 392-396.

Jenkins, J.H. and T.T. Findley, 1971a, Radiation in the White-Tailed Deer: An Evaluation of the Factors Involved in the Bioaccumulation of Gamma-Emitting Radionuclides in the White-Tailed Deer (Odocoileus virginianus), SRO-642-1, U.S. Atomic Energy Commission, Savannah River Operations Office, Aiken, South Carolina, pp. 38.

Jenkins, J.H. and T.T. Findley, 1971b, "Radionuclide Biomagnification in Coastal Plain Deer", In: Proceedings of the Third National Symposium on Radioecology, USAEC Document, CONF-7 1 050, pp. 116- 122.

Jorgensen, S.E., S.N. Nielson, and L.A. Jorgensen, 1991, Handbook of Ecological Parameters and Ecotoxicology, Elsevier, New York, NY, p. 843-848.

Kirkham, M.B., D.C. Adriano, and J.C. Corey, 1979, "Comparison of Plutonium Concentrations in Deer from the Southeastern United States and in Deer from an Integrated Nuclear Fuel Cycle Facility”, Health Physics, Vol. 36, pp. 516-519.

Marei, A.N., R.M. Barkhudarov, N.J. Novikova, E.V. Petukhova, L.D. Dubova, and V.M. Brigianina, 1972, "Effect of Natural Factors on Cesium-137 Accumulation in the Bodies of Residents in Some Geographical Regions", Health Physics, Vol. 22, pp. 9-15.

McLeod, K.W., D.L. Dawson, 1980, "Increased Cesium Uptake by Water Tupelo Under Inundated Conditions", Health Physics, Vol. 39, pp. 809-812.

McLeod, K.W., D.C. Adriano, and T.G. Ciravolo, July 1981, "Uptake of Plutonium from Soils Contaminated by a Nuclear Fuel Chemical Separations Facility”, Soil Science, Vol. 132, No. 1, pp. 89-98.

McLeod, K.W., J.J. Alberts, D.C. Adriano, and J.E. Pinder, III, 1984., "Plutonium Contents of Broadleaf Vegetable Crops Grown Near a Nuclear Fuel Chemical Separations Facility", Health Physics, Vol. 46, No. 2, pp. 261-267.

Miller, C.F., 1963, Fallout Nuclide Solubility, Foliage Contamination and Plant Part Uptake Contour Ratios, NP-13115, also AD-417665.

Murphy, Jr. C.E., 1984, "The Relationship Between Tritiated Water Activities in Air, Vegetation, and Soil Under SteadyState Conditions", Health Physics, Vol. 47, No. 4, pp. 635-639.

Murphy, Jr. C.E., 1992, The Concentration of Radionuclides and Metals in: Vegetation Adjacent to and in The SRL Seepage Basins, WSRC-TR-92-583, Westinghouse Savannah River Company.

Murphy, Jr. C.E., 1993, "Tritium Transport and Cycling in the Environment", Health Physics, Vol. 65, No. 6, pp. 683-697.

Murphy, Jr. C.E. and R.C. Tuckfield, "Transuranic Element Uptake and Cycling in a Forest Established over an Old Burial Ground", Paper for publication in Seminar on the Dynamics of the Behavior of Radionuclides in Contaminated Forests.

Newman, M.C. and Brisbin, Jr. I.L., 1990, "Variation of Cs-137 Levels Between Sexes, Body Sizes and Collection Localities of Mosquitofish, Gambusia Holbrook", Journal of Environmental Radioactivity, Vol. 12, pp. 131-141.

Nishita, H., E.M. Romney, and K.H. Larson, 1961, "Uptake of Radioactive Fission Products by Crop Plants", Journal of Agricultural Food Chemistry, Vol. 9, p. 101.

Nishita, H., A.J. Steen, and K.H. Larson, 1958, "Release of Strontium-90 and Cesium-137 from Vina Loam upon Prolonged Cropping”, Soil Science, Vol. 86, pp. 195-201. 
Ng, Y.C., 1982, "A Review of Transfer Factors for Assessing the Dose from Radionuclides in Agricultural Products", R.O. Chester and C.T. Garten (eds), Nuclear Safety, Vol. 23, No. 1, pp. 57-70.

Pinder, III J.E. and M.H. Smith, 1975, "Frequency Distributions of Radiocesium Concentrations in Soil and Biota", In: Mineral Cycling in Southeastern Ecosystems, F. G. Howell, J. B. Gentry, and M. H. Smith (eds.), ERDA Symposium Series, (CONF7405 13 ).

Pinder, III J.E., K.W. McLeod, J.J. Alberts, D.C. Adriano, and J.C. Corey, 1984, "Uptake of Cm-244, Pu-238 and Other Radionuclides by Trees Inhabiting a Contaminated Flood Plain”, Health Physics, Vol. 47, No. 3, pp. 375-384.

Pinder, III J.E. and A.C. Doswell, 1985, "Retention of ${ }^{238}$ Pu-Bearing Particles by Corn Plants", Health Physics, Vol. 49, No. 5, pp 771-776.

Poston, T.M. and D.C. Klopfer, 1988, "Concentration Factors Used in the Assessment of Radiation Dose to Consumers of Fish: A Review of 27 Radionuclides", Health Physics, Vol. 55, No. 5, pp. 751-766.

Radford, A.E., H.E. Ahles, and C.R. Bell, 1968, Manual of the Vascular Flora of the Carolinas, University of North Carolina Press, Chapel Hill, NC, 1183 pp.

Rabon, E.W., 1968, "Some Seasonal and Physiological Effects of Cs-137 and Sr-89,90 Content of the White-Tailed Deer, Odocoileus virginianus", Health Physics, Vol. 15, pp. 37-42.

Ragsdale, H.L. and D.J. Shure, 1973, "Flood Plain Transfer and Accumulation of ${ }^{137}$ Cs From A Reactor Effluent Stream", Environmental Behavior of Radionuclides Released in the Nuclear Industry, Symposium Proceedings, Aix-en-Province, France, IAEA-SM-172/33, pp. 243-252.

Reichle, D.E., P.B. Dunaway, and D. J. Nelson, 1970, "Turnover and Concentration of Radionuclides in Food Chains", Nuclear Safety, Vol. 11, No. 1, pp. 43-55.

Robertson, J.S., 1973, "Tritium Turnover Rates in Mammals", In: Tritium, Moghissi, A.A. and M.W. Carter (eds), Phoenix, AZ: Messenger Graphics, pp. 322-326.

Romney, E.M. and K.R. Price, 1970, "Persistence of Plutonium in Soil, Plants, and Small Mammals", Health Physics, Vol 19, pp. 487-491.

Russell, R.S. and H.M. Squire, 1958, "The Absorption and Distribution of Strontium in Plants. I. Preliminary Studies in Water Culture", Journal of Experimental Botany, Vol. 9, pp. 262-276.

Sharitz, R. R., S.L. Scott, J.E. Pinder III, S.K. Wood, 1975, "Uptake of Radiocesium From Contaminated Floodplain Sediments by Herbaceous Plants", Health Physics, Vol. 28, pp. 23-28.

Shulz, R.K., G.A. Tompkins, and K.L. Babcock, 1976, "Uptake of Plutonium and Americium by Plants from Soils: Uptake by Wheat from Various Soils and Effect of Oxidation State of Plutonium Added in Soil", In: Tansuranium Nuclides in the Environment, Symposium Proceedings, San Francisco, 1975, pp. 303-310, STIPUB/410, IAEA, Vienna.

Shure, D.J. and M.R. Gottschalk, 1975, "Cesium-137 Dynamics within a Reactor Effluent Stream in South Carolina", In: Radioecology and Resources, Proceedings of the Fourth National Symposium on Radioecology, The Ecological Society of America, Special Publication No. 1, C.E. Cushing, Jr. (ed.), pp. 234-241.

Sweet, C.W. and C.E. Murphy, Jr., 1984, "Tritium Deposition in Pines and Soil from Atmospheric Releases of Molecular Tritium", Environmental Science and Technology, Vol. 18, p. 358. 
Thompson, S.E., C.A. Burton, D.J. Quinn, and Y.C. Ng, October 10, 1972, Concentration Factors of Chemical Elements In Edible Aquatic Organisms, TID-4500, UC-48, URCL450564, Rev. 1, Biology and Medicine, Lawrence Livermore Laboratory, Bio-Medical Division.

Till, J.E. and H.R. Meyer (ed), 1983, Radiological Assessment, A Textbook on Environmental Dose Analysis, U.S. Nuclear Regulatory Commission, NUREG/CR-3332, Superintendent of Documents, U.S. Government Printing Office, Washington, D.C.

U.S. Nuclear Regulatory Commission, 1977, "Calculations of Annual Doses to Man from Routine Releases of Reactor Effluents for the Purpose of Evaluating Compliance with 10 CFR Part 50, Appendix I", Regulatory Guide 1.I09, Revision 1, Superintendent of Documents, U.S. Government Printing Office, Washington, D.C.

Vanderplog, H.A., D.C. Parzyck, W.H. Wilcox, J.R. Kercher, and S.V. Kaye, 1975, Bioaccumulation Factors for Radionuclides in Freshwater Biota, ORNL-5002, Environmental Sciences Division Publication, Number 783, Oak Ridge National Laboratory, Oak Ridge, TN.

Wallace, A., E.M. Romney, R.T. Mueller, and P.M. Patel, 1976, “24I Am Availability to Plants as Influenced by Chelating Agents", In: Radioecology and Energy Resources, Proceedings of Fourth Symposium on Radioecology, Oregon State University, May 12-14, 1975, pp. 104-107, C.E. Cushing (ed.) Ecological Society of America Special Publication Series No. 1, Academic Press, Inc. New York.

Whicker, F.W., W.C. Nelson, and A.F. Gallegos, 1972 , "Fallout of ${ }^{137} \mathrm{Cs}$ and ${ }^{90} \mathrm{Sr}$ in Trout from Mountain Lakes in Colorado", Health Physics, Vol. 23, pp. 519-527.

Whicker, F.W., J.E. Pinder III, J.W. Bowling, J.J. Alberts, and I.L. Brisbin, Jr., May 1989, Distribution of Cs-137, Sr-90, Pu-238, Pu-239, Am-241, and Cm-244 in Pond B, Savannah River Site, SREL-35, UC-66e, Savannah River Ecology Laboratory, Aiken, SC.

Whicker, F.W., J.E. Pinder III, J.W. Bowling, J.J. Alberts, and I.L. Brisbin, Jr., 1990, "Distribution of Long-Lived Radionuclides in an Abandoned Reactor Cooling Reservoir", Ecological Monographs, Vol. 60(4), pp. 471-496.

Whicker, F.W., D.J. Niquette, and T.G. Hinton, 1993, "To Remediate or Not: A Case History, in Environmental Health Physics", Proceedings of the Twenty-sixth Midyear Topical Meeting of the Health Physics Society, Kathren, Denham, and Salmon (eds.), pp. 473-485.

Yousef, M.K., 1973, “Tritium Turnover Rate in Desert Mammals", In: Tritium, Moghissi, A.A. and M.W. Carter, (eds), Phoenix, AZ: Messenger Graphics, pp. 333-340. 


\section{Appendix A}

\section{AQUATIC BIOCONCENTRATION FACTORS}

The following tables present bioconcentration factors that are specific to the Savannah River Site. The data were obtained from articles distributed internally at the SRS, articles published in technical journals, and from unpublished sources. An attempt was made to collect every available article that contained site specific bioconcentration factors, or data from which bioconcentration factors could be calculated; however, all information was probably not obtained. These tables provide sufficient information to select bioconcentration factors that are appropriate for the intended use. If more information is needed, the literature article should be reviewed. Figure 1 (Appendix C) is a general site map of the SRS. Table A-1 is divided into the following columns:

1. Medium - Organism or class of organisms for which the bioconcentration factor was calculated

2. Organsim - More specific information (e.g., the scientific name, the common name, the tissue part) about the organism for which the bioconcentration factor was calculated

3. BCF - The bioconcentration factor in scientific notation

4. $\quad \mathrm{N}$ - the sample size - if "comp" is given, then a.certain number of samples were collected and composited before analysis, so that only one analysis was performed. If a number is given, the bioconcentration factor was calculated from the mean value of that number of analyses on the medium.

5. General - The general area onsite from which the sample was collected.

6. Specific-More specific information about where the sample was collected

7. Radionuclide - The radionuclide for which the bioconcentration factor was calculated.

8. Comments - Additional information about the experimental conditions for the study

9. Reference - The reference from which the data were taken

Other abbreviations that are used in the tables include:

LTR - Lower Three Runs

Donora St. - Donora Station 
Table A 1: Bioconcentration Factors for SRS Flora and Fauna by Location and Radionuclide (Cummins, 1994).

\begin{tabular}{|c|c|c|c|c|c|c|c|c|}
\hline & & & & Loc & & & & \\
\hline Media & Organism & $\overline{B C F}$ & $\bar{N}$ & General & Specific & Radionuclide & Conditions & Reference \\
\hline Fish (Type 3)* & Large-mouth Bass, flesh (Micropterus salmoides) & $2.50 \mathrm{E}+03$ & & Pond B & & Am-241 & dry weight, filtered water & Whicker et. al. 1989 \\
\hline Fish (Type 4)* & Bullhead caffish, bone (Ictalurus natalis) & $4.20 \mathrm{E}+03$ & & Pond B & & Am-24I & dry weight, filtered water & Whicker et. al. 1989 \\
\hline Macroinvertebrate & Benthic, Gastropods, larvae & $7.80 \mathrm{E}+04$ & comp & Pond $\mathrm{B}$ & & $A m-241$ & dry weight, filtered water & Whicker et. al. 1989 \\
\hline Macroinvertebrate & Benthic, Insect nymphs, larvae & $2.40 \mathrm{E}+05$ & comp & Pond B & & $\mathrm{Am}=241$ & dry weight, filtered water & Whicker et. al. 1989 \\
\hline Macrophyte (Type 1$)^{* *}$ & Fanwort (Cabomba caroliniana) & $2.10 \mathrm{E}+04$ & & Pond B & & $\mathrm{Am}-241$ & dry weight, filtered water & Whicker et. al. 1989 \\
\hline Macrophyte (Type 1)*** & Water-shield (Brasenia schreberi) & $2.10 \mathrm{E}+03$ & & Pond B & & Am-241 & dry weight, filtered water & Whicker et. al. 1989 \\
\hline Macrophyte (Type 1)** & White water-lilly (Nymphaea odorafa) & $1,40 \mathrm{E}+03$ & & Pond B & & $A m-241$ & dry weight, filtered water & Whicker et. al. 1989 \\
\hline Macrophyte (Type 2)** & Bladderwort (Utricularia flaridana) & $7.50 E+04$ & & Pond B & & Am-24I & dry weight, filtered water & Whicker et. al. 1989 \\
\hline Sediment & & $1.10 \mathrm{E}+06$ & 15 & Pond B & $0-3 \mathrm{~cm}$ & $A m-241$ & dry weight, fjitered water & Whicker et. al. 1989 \\
\hline Turtle & Yellow-bellied Slider (Trachemys scripta), muscle & $5.60 \mathrm{E}+03$ & 10 & Pond B & & Am-241 & dry weight, filtered water & Whicker et. al. 1989 \\
\hline Waterfowl & American Coot (Fulica americana), muscle & $6.50 \bar{E}+02$ & 5 & Pond $B$ & & Am-24I & dry weight, filtered water & Whicker et. al. 1989 \\
\hline Clam & Lampsilis radiata, soft tissue & $9.00 \mathrm{E}+02$ & & & & Ce-144 & wet weight & Harvey 1969 \\
\hline Fish (Type 3)* & Large-mouth Bass, bone (Micropterus salmoides) & $1.40 \mathrm{E}+03$ & & Pond $\mathrm{B}$ & & $\mathrm{Cm}-244$ & dry weight, filtered water & Whicker et. al. 1989 \\
\hline Fish (Type 3)* & Large-mouth Bass, flesh (Micropterus salmoides) & $4.10 \mathrm{E}+02$ & & Pond B & & $\mathrm{Cm}-244$ & dry weight, filtered water & Whicker et. al. 1989 \\
\hline Fish (Type 4)* & Bullhead catfish, flesh (Ictalurus natalis) & $9.10 \mathrm{E}+01$ & & Pond B & & $\mathrm{Cm} \cdot 244$ & dry weight, filtered water & Whicker et. al. 1989 \\
\hline Macroinvertebrate & Benthic, Gastropods, larvae & $1.40 \mathrm{E}+03$ & & Pond $B$ & & $\mathrm{Cm}-244$ & dry weight, filtered water & Whicker et. al. 1989 \\
\hline Macroinvertebrate & Benthic, Insect nymphs, larvae & $1.90 \mathrm{E}+04$ & & Pond $\mathrm{B}$ & & $\mathrm{Cm} \cdot 244$ & dry weight, filtered water & Whicker et. al. 1989 \\
\hline Macrophyte (Type 1)** & Fanwor (Cabomba caroliniana) & $3.70 \mathrm{E}+02$ & & Pond $\mathrm{B}$ & & $\mathrm{Cm}-244$ & dry weight, filtered water & Whicker et. al. 1989 \\
\hline Macrophyte (Type 1)** & Water-shield (Brasenia schreberi) & $8.40 \mathrm{E}+01$ & & Pond B & & $\mathrm{Cm}-244$ & dry weight, filtered water & Whicker et. al. 1989 \\
\hline Macrophyte (Type 1)** & White water-lilly (Nymphaea odorata) & $1.90 \mathrm{E}+02$ & & Pond $B$ & & $\mathrm{Cm}-244$ & dry weight, filtered water & Whicker et. al. 1989 \\
\hline Macrophyte (Type 2)** & Bladderwort (Utricularia floridana) & $7.80 \mathrm{E}+02$ & & Pond $\mathrm{B}$ & & $\mathrm{Cm}-244$ & dry weight, filkered water & Whicker et. al. 1989 \\
\hline Sediment & & $1.50 \mathrm{E}+04$ & 15 & Pond $\mathrm{B}$ & $\overline{0-3 \mathrm{~cm}}$ & $\mathrm{Cm}-244$ & dry weight, filtered water & Whicker et. al. 1989 \\
\hline Turtle & Yellow-bellied Slider, (Trachemys scripta), muscle & $1.10 \mathrm{E}+02$ & 10 & Pond B & & $\mathrm{Cm}-244$ & dry weight, filtered water & Whicker et. al. 1989 \\
\hline Turtle & $\begin{array}{l}\text { Yellow-bellied Slider, (Trachemys scripta), shell \& } \\
\text { bone }\end{array}$ & $1.90 \mathrm{E}+02$ & 10 & Pond $B$ & & $\overline{C m-244}$ & dry weight, filtered water & Whicker et. al. 1989 \\
\hline Waterfowl & American Coot, (Fulica americana), muscle & $1.10 \mathrm{E}+02$ & 5 & Pond B & & $\mathrm{Cm}-244$ & dry weight, filtered water & Whicker et. al. 1989 \\
\hline Clam & Lampsilis radiata, soft tissue & $7.90 \mathrm{E}+02$ & & & & Co-60 & wet weight & Harvey 1969 \\
\hline
\end{tabular}




\begin{tabular}{|c|c|c|c|c|c|c|c|c|}
\hline 6861 ' & 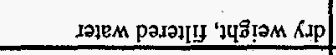 & $\angle E[-S \mathcal{S}$ & & g puod & & to+g08t & 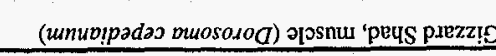 & $*\left(S \partial d K_{L}\right)$ $) s: g$ \\
\hline$\$ 96 \mathrm{I}$ КəAreH & 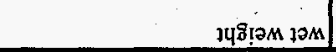 & $\lfloor\varepsilon[-s)$ & & puod $x_{\mathrm{d}}$ & duroo & $\varepsilon 0+90 z: I$ & 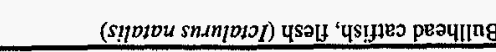 & 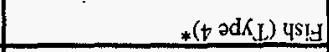 \\
\hline 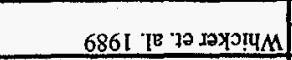 & 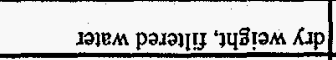 & $L E[-5]$ & & $\mathrm{gpuod}_{\mathrm{d}}$ & & $t 0+9062$ & 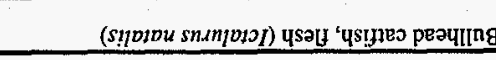 & 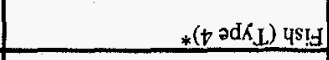 \\
\hline t966 калген & 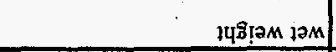 & $\angle E[-5 \mathcal{S}$ & & puod $x_{\mathrm{d}}$ & duros & $20+9008$ & 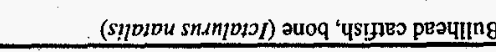 & $*(t$ əd $K \mathcal{L})$ us! \\
\hline 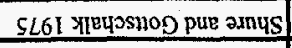 & 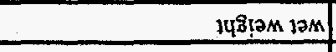 & $L E 1-s \mathrm{~S}$ & IS Exowod & QLIT & 9 & $20+9806$ & (dds xosg ) parxpold & 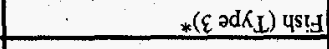 \\
\hline t961 Кəser & 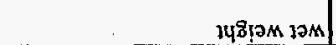 & $L E[-s]$ & & puod $\mathbb{1 E d}_{\mathrm{d}}$ & duos & $\varepsilon_{0}+30 z \div$ & 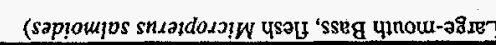 & $*\left(\varepsilon \partial \mathrm{\partial} K_{\mathrm{I}}\right)$ पs, \\
\hline 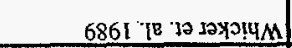 & 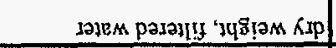 & $L \varepsilon_{1}^{-S \mathrm{~S} S}$ & & g puod & & $t 0+306 \varepsilon$ & 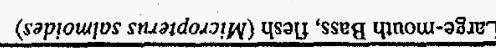 & $*\left(\varepsilon \partial \mathrm{d} K_{\mathrm{I}}\right)$ पs. \\
\hline 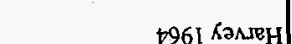 & зч: & $L \varepsilon 1-s \jmath$ & & puod $x_{d}$ & dwoos & $20+900 s$ & 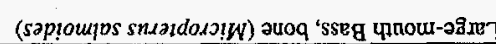 & 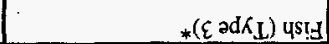 \\
\hline 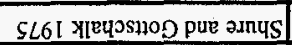 & $148 \mathrm{~g} 2 \mathrm{M} 1 \mathrm{MM}$ & $\angle \mathcal{L E}-s \mathcal{S J}$ & IS erouog & $8 \mathrm{LIT}$ & \pm & $\varepsilon 0+908 \tau$ & 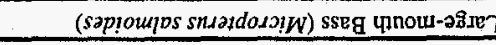 & 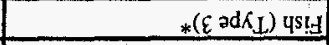 \\
\hline 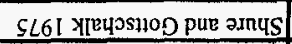 & $14 \mathrm{~g}$ & $L E I^{-S S}$ & IS erouog & \&LIT & $\varepsilon$ & $\mathcal{E} 0+\not{E E E} 1$ & 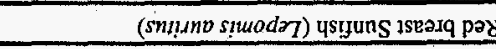 & $*\left(Z 2 \mathrm{ad} K_{\mathrm{L}}\right)$ YSIS \\
\hline 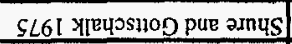 & 848:19m $19 \mathrm{~m}$ & $L E[-s]$ & is erouog & עIT & $\varepsilon \varepsilon$ & $20+902 L$ & 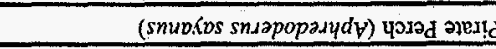 & $*\left(Z\right.$ ad $\left.K_{\mathrm{L}}\right)$ पs.t. \\
\hline 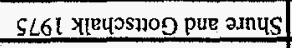 & 148 & $L E[\cdot-S \mathcal{S}$ & is erourag & पـT & 7 & $20+9169$ & 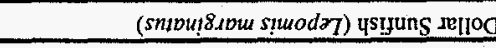 & $*\left(Z\right.$ add $\left.K_{I}\right)$ पSS: \\
\hline t961 КәAMH & 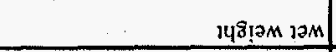 & $\angle E I_{-S O}$ & & puod $\pi_{d}$ & duos & $20+3006$ & 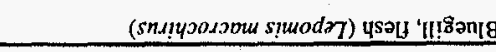 & $*(z \ni \mathrm{d} \Omega$ \\
\hline$+96 \mathrm{~L}$ К $А \mathrm{NBH}$ & 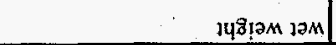 & $\angle \varepsilon 1-s \mathcal{S}$ & & $p w o_{d} \mathbb{N}_{\mathrm{d}}$ & dwoos & $20+9009$ & 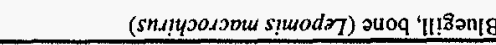 & 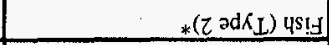 \\
\hline 0661 u!gsug pue ueumas & 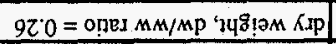 & $L E I-s J$ & 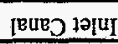 & g puod & $6 \mathrm{l}$ & $+0+7 E L I I$ & 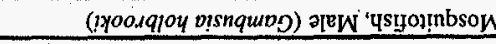 & $\left.*(1) 2 \mathrm{~d} \mathrm{~K}_{\mathrm{L}}\right)$ чs \\
\hline 066l uIgsug pue ueuməN & 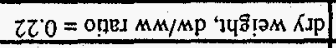 & $\angle E[-s]$ & 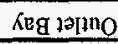 & g puod & 62 & $+0+7 \varepsilon 0^{\prime} l$ & 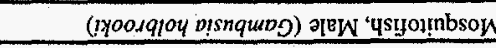 & 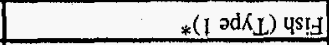 \\
\hline 066I urgsug pur reuma N & 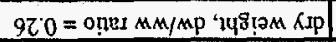 & $L \varepsilon_{1}-s_{5}$ & 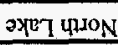 & g puod & $8 z$ & $\varepsilon 0+\frac{8}{6} L^{\prime} 8$ & 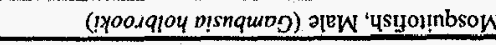 & $*\left(I\right.$ ad $\left.K_{\mathrm{L}}\right)$ ) $S \mathrm{~S}: \mathrm{S}$ \\
\hline 0661 ugqugug pue uвzuman & 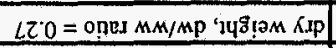 & 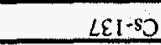 & 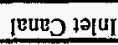 & g puod & IE & $\varepsilon 0+39 \varepsilon L$ & 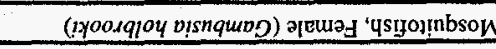 & $*\left(1\right.$ ad $\left.K_{L}\right)$ 4 45.9 \\
\hline 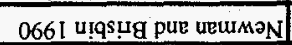 & 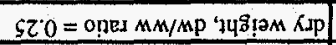 & $L E[-s$, & Keg IPpno & $\mathrm{gpuOd}_{\mathrm{d}}$ & $s \leqslant$ & $\varepsilon_{0}+g<t^{\prime} 8$ & 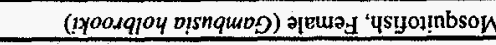 & $*\left(1\right.$ əd $\left.\kappa_{I}\right) 45$ \\
\hline $066 \mathrm{I}$ u!gsug pue ueuiməN & 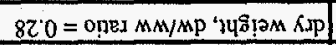 & $L \mathcal{L E I - S \mathcal { S }}$ & 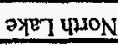 & g prod & $8 z$ & $\varepsilon 0+306 \mathrm{~L}$ & 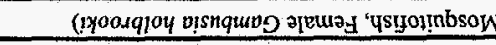 & 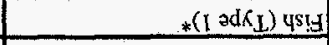 \\
\hline 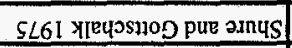 & 348 & $\angle \mathcal{E}[-5 \mathcal{S}$ & IS rrouog & QLIT & $\varepsilon \tilde{\varepsilon \tau}$ & $20+9168$ & 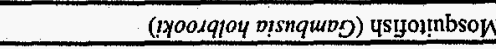 & 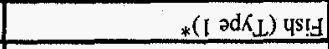 \\
\hline 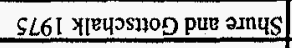 & 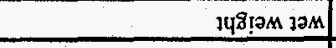 & $\angle E I-S 5$ & IS erouod & प्रIT & 561 & $80+960^{\circ} \mathrm{l}$ & 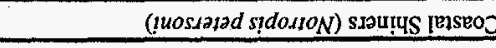 & $*(1$ गdKL) पs:H \\
\hline 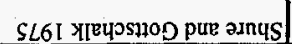 & 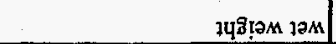 & $L E[-s]$ & IS exoutod & ILIT & & $20+98 \varepsilon^{6} 6$ & дәэпроге & snumpag \\
\hline SLGI Yाएप९Sม & $348212 \mathrm{M}+2 \mathrm{M}$ & $\angle \mathcal{L E}-s_{\mathcal{S}}$ & IS erouog & 8.1 & 68 & $20+9 \angle 66$ & sninsily snapquiboodo & पSIYKRE \\
\hline 696I KOnRH & 148 & $L E L-s_{S}$ & & & & $20+90 z \tau$ & 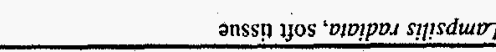 & urelo \\
\hline $696[$ КәменH & 148 & $L E[-5 \mathcal{S}$ & & & & $10+9052$ & 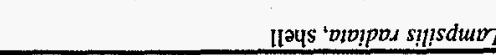 & ureIJ \\
\hline 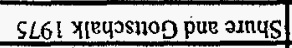 & 1488? $19 \mathrm{~m}$ & $\angle E I-S \mathcal{S}$ & IS erouog & $8 \mathrm{LLT}$ & 16 & $20+900 \varepsilon$ & pnpuplduos old d!lta & uel] \\
\hline 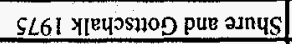 & $34819 \mathrm{M} 19 \mathrm{M}$ & $\angle E 1-5 \mathcal{S}$ & IS prouog & प्रLT & $+6 t$ & $20+908 t$ & ('ds samaut $G$ ) 8! & sรp] $209 \mathrm{~g}$ \\
\hline 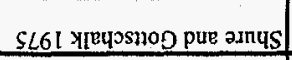 & 348 & $L \varepsilon 1 \cdot-s \mathrm{~S}$ & IS erovog & ב & & $\varepsilon 0+30 s t$ & un!ưosopac & $208[y$ \\
\hline t961 калавн & 148 & 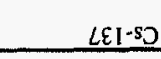 & & puod ${ }^{2} \mathbf{p e}_{d}$ & duros & $\varepsilon 0+90 z^{\prime} \mathrm{l}$ & 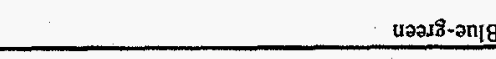 & $x e^{8} I Y$ \\
\hline $696 \mathrm{КәАРЕН}$ & 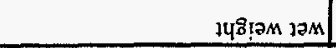 & {$[5-1]$} & & & & $20+900+t$ & 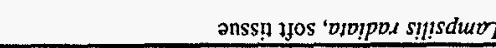 & urip \\
\hline әэиә.әуау & suo!npuos & әpyjonuoppey & og!a dS & венана & $N$ & sog & 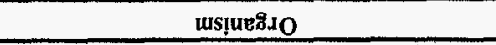 & в!paw \\
\hline & & & uo! & & & & & 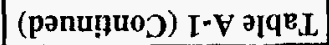 \\
\hline
\end{tabular}




\begin{tabular}{|c|c|c|c|c|c|c|c|c|}
\hline \multirow{2}{*}{\begin{tabular}{|c|} 
Table A-1 (Continued) \\
Media \\
\end{tabular}} & \multirow[b]{2}{*}{ Organism } & \multirow[b]{2}{*}{$\overline{B C F}$} & \multirow[b]{2}{*}{$N$} & \multicolumn{2}{|c|}{ Location } & \multirow[b]{2}{*}{ Radionuclide } & \multirow[b]{2}{*}{ Conditions } & \multirow[b]{2}{*}{ Reference } \\
\hline & & & & General & Specific & & & \\
\hline Insects & Dragonflies (Anisoptera) & $6.48 \mathrm{E}+02$ & 118 & LTR & Donora St. & Cs-137 & wet weight & Shure and Gotschalk 1975 \\
\hline Macroinvertebrate & Benthic, Gastropods, larvae & $1.20 \mathrm{E}+03$ & & Pond $B$ & & Cs-137 & dry weight, filtered water & Whicker et. al. 1989 \\
\hline Macroinvertebrate & Benthic, Insect nymphs, larvae & $8.00 \mathrm{E}+03$ & & Pond B & & $\mathrm{Cs}_{\mathrm{s}-137}$ & dry weight, filtered water & Whicker et. al. 1989 \\
\hline Macrophyte (Type 1)** & Fanwort (Cabomba caroliniana) & $3.70 \mathrm{E}+04$ & $\sqrt{32}$ & Pond B & & Cs-137 & dry weight, filtered water & Whicker et. al. 1989 \\
\hline Macrophyte (Type 1)** & Floating heart (Nymphoides cordata) & $3.10 \mathrm{E}+04$ & 29 & Pond B & & Cs-137 & dry weight, filtered water & Whicker et. al. 1989 \\
\hline Macrophyte (Type 1)** & Potomogeton pectinatus & $2.95 \mathrm{E}+02$ & & $\overline{\text { LTR }}$ & Donora St. & Cs-137 & wet weight & Shure and Gottschalk 1975 \\
\hline Macrophyte (Type 1)** & Water-shield (Brasenia schreberi) & $2.50 \mathrm{E}+04$ & 48 & Pond B & & Cs-137 & dry weight, filtered water & Whicker et. al. 1989 \\
\hline Macrophyte (Type 1)** & White water-lilly (Nymphaea odorata) & $1.90 \mathrm{E}+04$ & 4 & Pond B & & Cs-137 & dry weight, filtered water & Whicker et. al. 1989 \\
\hline Macrophyte (Type 2)** & Bladderwort (Utricularia floridana) & $1.70 \mathrm{E}+04$ & 39 & Pond B & & Cs-137 & dry weight, filtered water & Whicker et. al. 1989 \\
\hline Macrophyte (Type 3)** & Smartweed $(P$. punctatum $)$ & $\sqrt[7.16 \mathrm{E}+02]{2}$ & 72 & LTR & Donora St. & Cs-137 & wet weight & Shure and Gotschalk 1975 \\
\hline Macrophyte (Type 3)** & Smartweed, leaves $(P$. punctatum $)$ & $3.42 \mathrm{E}+03$ & 6 & LTR & & Cs-137 & & Gladden 1979 \\
\hline Macrophyte (Type 3)** & Snartweed, roots $(P$. punctatum $)$ & $4.66 \mathrm{E}+03$ & 6 & LTR & & Cs-137. & & Gladden 1979 \\
\hline Macrophyte (Type 3)** & Knotweed (P. densifforum) & $77.34 E+02$ & $\sqrt{78}$ & LTR & & $\mathrm{Cs}_{\mathrm{S}-137}$ & wet weight & Shure and Gottschalk 1975 \\
\hline Sediment & & $3.20 \mathrm{E}+04$ & 15 & Pond B & $0-3 \mathrm{~cm}$ & Cs-137 & dry weight, filtered water & Whicker et. al. 1989 \\
\hline Shrimp & Palaemonetes paludosus & $8.67 \mathrm{E}+02$ & 505 & LTR & & Cs-137 & wet weight & Shure and Gottschalk 1975 \\
\hline Snails & Capeloma sp. & $2.60 \mathrm{E}+02$ & 397 & LTR & & Cs-137 & wet weight & Shure and Gottschalk 1975 \\
\hline Snakes & Water Snakes (Natrix sipedon) & $2.60 \mathrm{E}+03$ & 2 & $\overline{\mathrm{LTR}}$ & & Cs-137 & wet weight & Shure and Gottschalk 1975 \\
\hline Spiders & Fishing (Dolomedes sexpunctatus) & $1.28 E+03$ & 78 & LTR & & Cs-137 & wet weight & Shure and Gottschalk 1975 \\
\hline Suspended Particles & $>5 \mathrm{um}$ & $4.24 \mathrm{E}+03$ & & LTR & Donora St. & CS-137 & wet weight & Shure and Gottschalk 1975 \\
\hline Suspended Particles & $880 \mathrm{um}$ & $2.25 \mathrm{E}+03$ & & LTR & & Cs-137 & wet weight & Shure and Gottschalk 1975 \\
\hline Turtle & Yellow-bellied Slider, (Trachemys scripta), muscle & $1.30 \mathrm{E}+04$ & 10 & Pond B & & Cs-137 & dry weight, filtered water & Whicker et. al. 1989 \\
\hline Turle & $\begin{array}{l}\text { Yellow-bellied Slider, (Trachemys scripta), shell \& } \\
\text { bone }\end{array}$ & $1.10 E+03$ & 10 & Pond $\mathrm{B}$ & & Cs-137 & dry weight, filtered water & Whicker et. al. 1989 \\
\hline Waterfowl & American Coot, (Fulica americana), bone & $2.90 \mathrm{E}+02$ & 1 & Pond B & & Cs-137 & dry weight, filtered water & Whicker et. al. 1989 \\
\hline Waterfowl & American Coot, (Fulica americana), muscle & $1.90 \mathrm{E}+04$ & 7 & Pond B & & Cs-137 & dry weight, filtered water & Whicker et. al. 1989 \\
\hline Zooplankton & & $7.10 \mathrm{E}+04$ & 15 & H Area & & Cs-137 & dry weight, filtered water & Whicker et. al. 1989 \\
\hline Clam & Lampsilis radiata, shell & $1.15 \mathrm{E}+03$ & & & & Mn-54 & wet weight & Harvey 1969 \\
\hline Clam & 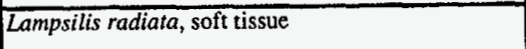 & $2.38 \mathrm{E}+03$ & & & & Mn-54 & wet weight & Harvey 1969 \\
\hline
\end{tabular}




\begin{tabular}{|c|c|c|c|c|c|c|c|c|}
\hline Table A-1 (Continued) & & & & & & & & \\
\hline Media & Organism & BCF & $\overline{\mathbf{N}}$ & General & Specific & \begin{tabular}{|l} 
Radionuclide \\
\end{tabular} & $\begin{array}{ll}\text { Conditions } \\
\text {. }\end{array}$ & Reference \\
\hline Fish (Type 3)* & Large-mouth Bass, bone (Micropterus salmoides) & $1.70 \mathrm{E}+04$ & & Pond B & & Pu-238 & dry weight, filtered water & Whicker et. al. 1989 \\
\hline Fish (Type 3)* & Large-mouth Bass, flesh (Micropterus salmoides) & $2.60 \mathrm{E}+03$ & & Pond B & & Pu-238 & dry weight, filtered water & Whicker et. al. 1989 \\
\hline Fish (Type 4)* & Bullhead caffish, flesh (Icralurus natalis) & $1.20 \mathrm{E}+04$ & & Pond B & & Pu-238 & dry weight, filtered water & Whicker et. al. 1989 \\
\hline Macroinvertebrate & Benthic, Insect nymphs, larvae & $8.40 \mathrm{E}+05$ & & Pond B & & Pu-238 & dry weight, filtered water & Whicker et. al. 1989 \\
\hline Macrophyte (Type 1)** & Fanwort (Cabomba caroliniana) & $5.00 \mathrm{E}+04$ & 21 & Pond B & & Pu-238 & dry weight, filtered water & Whicker et. al. 1989 \\
\hline Macrophyle (Type 1)** & Foating heart (Nymphoides cordata) & $7.80 \mathrm{E}+04$ & 10 & Pond B & & Pu-238 & dry weight, filtered water & Whicker et. al. 1989 \\
\hline Macrophyte (Type 1)** & Water-shield (Brasenia schreberi) & $3.60 \mathrm{E}+04$ & 12 & Pond B & & Pu-238 & dry weight, filtered water & Whicker et. al. 1989 \\
\hline Macrophyte (Type 1)** & White water-lilly (Nymphaea odorata) & $1.70 \mathrm{E}+04$ & 116 & Pond B & & Pu-238 & dry weight, filtered water & Whicker et. al. 1989 \\
\hline Macrophyte $(\text { Type } 2)^{* *}$ & Bladderwort (Utricularia floridana) & $9.10 \mathrm{E}+04$ & 12 & Pond B & & $\widehat{P u-238}$ & dry weight, filtered water & Whicker et. al. 1989 \\
\hline Sediment & & $1.10 \mathrm{E}+06$ & 15 & Pond B & $0.3 \mathrm{~cm}$ & Pu-238 & dry weight, filtered water & Whicker et. al. 1989 \\
\hline Turte & Yellow-bellied Slider, (Trachemys scripta), muscle & $1.40 \mathrm{E}+04$ & 10 & Pond B & & Pu-238 & dry weight, filtered water & Whicker et. al. 1989 \\
\hline Turtle & $\begin{array}{l}\text { Yellow-bellied Slider, (Trachemys scripta), shell \& } \\
\text { bone }\end{array}$ & $1.90 \mathrm{E}+04$ & 10 & Pond B & & Pu-238 & dry weight, filtered water & Whicker et. al. 1989 \\
\hline Waterfow 1 & American Coot, (Fulica americana), bone & $1.80 \mathrm{E}+04$ & 1 & Pond $B$ & & Pu-238 & dry weight, filtered water & Whicker et. al. 1989 \\
\hline Waterfow1 & American Coot, (Fulica americana), muscle & $3.80 \mathrm{E}+03$ & 5 & Pond $B$ & & Pu-238 & diry weight, filtered water & Whicker et. al. 1989 \\
\hline Fish (Type 3)* & Large-mouth Bass, flesh (Micropterus salmoides) & $5.60 \mathrm{E}+03$ & & Pond B & & Pu-239 & dry weight, filtered water & Whicker et. al. 1989 \\
\hline Macroinvertebrate & Benthic, Insect nymphs, larvae & $1.90 \mathrm{E}+05$ & & $\begin{array}{l}\text { Pond B } \\
\end{array}$ & & Pu-239 & dry weight, filtered water & Whicker et. al. 1989 \\
\hline Macrophyte (Type 1)** & Fanwort (Cabomba caroliniana) & $5.20 \mathrm{E}+04$ & 21 & Pond B & & Pu-239 & dry weight, filtered water & Whicker et. al. 1989 \\
\hline Macrophyte (Type 1)** & Floating heart (Nymphoides cordata) & $3.00 \mathrm{E}+04$ & 10 & Pond B & & $\overline{\text { Pu-239 }}$ & dry weight, filtered water & Whicker et. al. 1989 \\
\hline Macrophyte (Type 1)** & Water-shield (Brasenia schreberi) & $1.60 \mathrm{E}+04$ & $\frac{12}{12}$ & Pond B & & Pu-239 & dry weight, filtered water & Whicker et. al. 1989 \\
\hline Macrophyte (Type 1)** & White water-lilly (Nymphaea odorafa) & $6.60 \mathrm{E}+03$ & 16 & $\overline{\text { Pond } B}$ & & Pu-239 & dry weight, filtered water & Whicker et. al. 1989 \\
\hline Macrophyte (Type 2)** & Bladderwort (Utricularia floridana) & $1.00 \mathrm{E}+05$ & 12 & Pond B & & Pu-239 & dry weight, filtered water & Whicker et. al. 1989 \\
\hline Sediment & & $5.90 \mathrm{E}+06$ & 15 & Pond B & $0-3 \mathrm{~cm}$ & Pu-239 & dry weight, filtered water & Whicker et. al. 1989 \\
\hline Turtle & Yellow-bellied Slider, (Trachemys scripta), muscle & $6.60 \mathrm{E}+03$ & 10 & Pond B & & Pu-239 & dry weight, filtered water & Whicker et. al. 1989 \\
\hline Waterfowl & American Coot, (Fulica americana), muscle & $8.50 \mathrm{E}+02$ & 5 & Pond B & & Pu-239 & dry weight, filtered water & Whicker et. al. 1989 \\
\hline Zooplankion & & $2.30 \mathrm{E}+04$ & & Pond $B$ & & Pu-239 & dry weight, fillered water & Whicker et. al. 1989 \\
\hline Clam & Lampsilis radiata, soft tissue & $2.40 \mathrm{E}+02$ & & & & S-35 & wet weight & Harvey 1969 \\
\hline
\end{tabular}




\begin{tabular}{|c|c|c|c|c|c|c|c|c|}
\hline Table A-1 (Continued) & . & & & & & & & \\
\hline Media & Organism & $\overline{B C F}$ & $\bar{N}$ & General & \begin{tabular}{|l} 
Specificic \\
\end{tabular} & Radionuclide & Conditions & Reference \\
\hline Algae & Blue-green & $6.00 \mathrm{E}+02$ & comp & Par Pond & & Sr-89,90 & wet weight & $\longdiv { \text { Harvey } 1 9 6 4 }$ \\
\hline Fish (Type 2)* & Bluegill, bone, (Lepomis macrochirus) & $2.40 \mathrm{E}+03$ & comp & Par Pond & & SI- $-89,90$ & wet weight & Harvey 1964 \\
\hline Fish (Type 2)* & Bluegill, flesh, (Lepomis macrochirus) & $<48$ & comp & Par Pond & & St-89,90 & wet weight & Harvey 1964 \\
\hline Fish (Type 3)* & Large-mouth Bass, bone (Micropterus salmoides) & $1.70 \mathrm{E}+03$ & comp & Par Pond & & Sr-89,90 & wet weight & Harvey 1964 \\
\hline Fish (Type 3)* & Large-mouth Bass, flesh (Micropterus salmoides) & $<48$ & comp & Par Pond & & Sr-89,90 & wet weight & Harvey 1964 \\
\hline$\sqrt{\text { Fish (Type 4)* }}$ & Bullhead catfish, bone Ictalurus natalis) & $2.10 \mathrm{E}+03$ & comp & Par Pond & & SI-89,90 & Wet weight & Harvey 1964 \\
\hline Fish (Type 4)* & \begin{tabular}{|l} 
Bullhead catfish, flesh (Ictalurus natalis) \\
\end{tabular} & $<48$ & comp & Par Pond & & S- $-89,90$ & wet weight & Harvey 1964 \\
\hline Clam & Lampsilis radiata, shell & $1.33 \mathrm{E}+03$ & & & & St-90 & wet weight & Harvey 1969 \\
\hline Fish (Type 3)* & Large-mouth Bass, bone (Micropterus salmoide) & $6.30 \mathrm{E}+04$ & & Pond B & & St-90 & dry weight, filtered water & Whicker et. al. 1989 \\
\hline Fish (Type 3)* & Large-mouth Bass, flesh (Micropterus salmoides) & $3.40 \mathrm{E}+03$ & & Pond $B$ & & $S R-90$ & dry weight, filtered water & Whicker et. al. 1989 \\
\hline Fish (Type 4)* & Bullhead carfish, bone (Ictalurus natalis) & $5.70 E+04$ & & Pond B & & $5 r-90$ & dry weight, filtered water & Whicker et. al. 1989 \\
\hline$\sqrt{\text { Fish (Type 4)* }}$ & Bullhead catfish, flesh (Ictalurus natatis) & $6.10 E+02$ & & Pond $B$ & & Sr-90 & dry weight, filtered water & Whicker et. al. 1989 \\
\hline Fish (Type 5)* & Gizzard Shad, bone (Dorosoma cepedianum) & $5.10 E+04$ & & Pond $B$ & & Sr-90 & dry weight, filtered water & Whicker et. al. 1989 \\
\hline Macroinvertebrate & Benthic, Gastropods, larvae & $5.40 E+04$ & & Pond B & & $5 r-90$ & dry weight, filtered water & Whicker et. al. 1989 \\
\hline Macroinvertebrate & Benthic, Insect nymphs, larvae & $5.20 E+02$ & & Pond B & & Sr-90 & dry weight, filtered water & Whicker et. af. 1989 \\
\hline Macrophyce (Type 1)** & Fanwort (Cabomba caroliniana) & $6.00 E+03$ & & Pond B & & Sr-90 & dry weight, filtered water & Whicker et. a]. 1989 \\
\hline$\sqrt{\text { Macrophyte (Type 1)** }}$ & Foating heart (Nymphoides cordata) & $5.40 \mathrm{E}+03$ & & Pond B & & $S t-90$ & dry weight, filtered water & Whicker et. al. 1989 \\
\hline Macrophyte (Type 1)** & Water-shield (Brasenia schreberi) & $8.50 \mathrm{E}+03$ & & Pond B & & Sr-90 & dry weight, filtered water & Whicker et. al. 1989 \\
\hline Macrophyte (Type 1)** & White water-1illy (Nymphaea odordita) & $2.10 \mathrm{E}+03$ & & Pond B & & Sr-90 & dry weight, filtered water & Whicker et. al. 1989 \\
\hline$\overline{\text { Macrophyte (Type 2)** }}$ & Bladderwor (Utricularia floridana) & $9.40 \mathrm{E}+03$ & & Pond B & & Sr-90 & dry weight, filtered water & Whicker et. al. 1989 \\
\hline Sediment & & $1.20 \mathrm{E}+03$ & & Pond B & $\overline{0-3 \mathrm{~cm}}$ & Sr-90 & dry weight, filtered water & Whicker et. al. 1989 \\
\hline Zooplankion & & $3.90 \mathrm{E}+03$ & & Pond B & & St-90 & dry weight, filtered water & Whicker et. al. 1989 \\
\hline Algae & B]ue-green & $6.00 \mathrm{E}+03$ & comp & Par Pond & & $\mathrm{Zn}-65$ & wet weight & Harvey 1964 \\
\hline Clam & Lampsilis radiata, soft tissue & $4.08 \mathrm{E}+03$ & & & & $\mathrm{Zn}-65$ & wet weight & Harvey 1969 \\
\hline Fish (Type 2)* & Bluegill, bone, (Lepomis macrochirus) & $8.20 \mathrm{E}+03$ & comp & Par Pond & & $\mathrm{Zn}-65$ & wet weight & Harvey 1964 \\
\hline Fish (Type 2)* & Bluegill, flesh, (Lepomis macrochirus) & $1.60 \mathrm{E}+03$ & comp & Par Pond & & $2 \mathrm{n}-65$ & wet weight & Harvey 1964 \\
\hline
\end{tabular}




\begin{tabular}{|c|c|c|c|c|c|c|c|c|}
\hline Table A-1 (Continued) & & & & Loc & & & & \\
\hline Media & Organism & $\overline{B C F}$ & $\bar{N}$ & General & Specific & Radionuclide & Conditions & Reference \\
\hline Fish (Type 3)* & Large-mouth Bass, bone (Micropterus salmoides) & $1.40 \mathrm{E}+03$ & comp & Par Pond & & $2 \mathrm{n}-65$ & wet weight & Harvey 1964 \\
\hline Fish (Type 3)* & Large-mouth Bass, flesh (Micropterus salmoides) & $6.00 \mathrm{E}+02$ & comp & Par Pond & & $2 n-65$ & wet weight & Harvey 1964 \\
\hline Fish (Type 4)* & Bullhead catfish, bone (Ictalurus natalis) & $3.00 \mathrm{E}+03$ & comp & Par Pond & & $2 n-65$ & wet weight & Harvey 1964 \\
\hline Fish (Type 4)* & Bullhead catfish, flesh (Ictalurus natalis) & $8.00 \mathrm{E}+02$ & comp & Par Pond & & $2 \mathrm{p}-65$ & wet weight & Harvey 1964 \\
\hline
\end{tabular}

* Fish

Type $1=$ surface and midwater insectivores

Type 2 = Insect and bottom invertebrate feeders

Type $3=$ Piscivores

Type 4 = Benthic invertebrate and fish feeders

Type $5=$ Detritus and Plankton feeders

** Macroinvertebrate Types

Type $1 \approx$ Rooted vascular

Type $2 \approx$ Floating vascular

Type $3=$ emergent wetland

1. Medium - Organism or class of organisms for which the bioconcentration factor was calculated

2. Organsim - More specific information (e.g., the scientific name, the common name, the tissue part) about the organism for

which the bioconcentration factor was calculated

BCF - The bioconcentration factor in scientific notation

4. $\quad \mathrm{N}$ - the sample size - if "comp" is given, then a certain number of samples were collected and composited before analysis, so

that only one analysis was performed. If a number is given, the bioconcentration factor was calculated from the mean value of that number of analyses on the medium.

5. General - The general area onsite from which the sample was collected.

Specific - More specific information about where the sample was collected

Radionuclide - The radionuclide for which the bioconcentration factor was calculated.

Comments - Additional information about the experimental conditions for the study

Reference - The reference from which the data were taken

Other abbreviations that are used in the tables include:

LTR - Lower Three Runs

Donora St. - Donora Station 
Table A-2 : Radioactivity and Bioconcentration Factors (BCF) of Cs-137 for Biotic (Bq/L) Components at Selected SRS Impoundments, 1993-1996 (Hinton, 1996).

\begin{tabular}{|c|c|c|c|c|c|c|c|c|c|}
\hline \multirow[t]{2}{*}{ Life Form or Media } & \multirow[t]{2}{*}{ Scientific Name } & \multirow[t]{2}{*}{ Location } & \multirow[t]{2}{*}{ BCF } & \multicolumn{6}{|c|}{ Radioactivity $(B q / g$ or $B q / L)$} \\
\hline & & & & Minimum & Maximum & Mean & $\mathbf{N}$ & Std. Dev. & Std. Error \\
\hline \multirow[t]{12}{*}{ Rooted Floating Macrophytes } & Hydrocotyle umbrelleta & Pond $B$ & 37,968 & 11.77 & 11.77 & N/A & 1 & N/A & N/A \\
\hline & Hydrocotyle umbrelleta & Pond 5 & 167 & 0.003 & 0.003 & N/A & 1 & N/A & N/A \\
\hline & Brasenia schreberi & Pond B & 27,310 & 6.71 & 9.67 & 8.466 & 11 & 0.856 & 0.258 \\
\hline & Brasenia schreberi & Par Pond & 3,835 & 0.3 & 0.57 & 0.464 & 12 & 0.093 & 0.027 \\
\hline & Nelumbo lutea & L-Lake & 7,900 & 0.06 & 0.09 & 0.079 & 3 & 0.018 & 0.01 \\
\hline & Nelumbo lutea & Pond $\mathrm{B}$ & 42,516 & 5.18 & 18.13 & 13.18 & 13 & 4.577 & 1.269 \\
\hline & Nelumbo lutea & Par Pond & 12,570 & 0.81 & 0.206 & 1.521 & 41 & 0.324 & 0.051 \\
\hline & Nymphaea odorata & Pond B & 20,590 & 5.16 & 8.41 & 6.383 & 14 & 0.935 & 0.25 \\
\hline & Nymphaea odorata & Pond 5 & 9,500 & 0.095 & 0.267 & 0.171 & 6 & 0.075 & 0.031 \\
\hline & Nymphaea odorata & Par Pond & 4,488 & 0.28 & 0.94 & 0.543 & 41 & 0.201 & 0.031 \\
\hline & Nymphoides aquatica & Pond B & 52,497 & 15.28 & 17.27 & 16.274 & 2 & 1.405 & 0.993 \\
\hline & Nymphoides spp. & Pond B & 11,355 & 3.52 & 3.52 & N/A & 1 & N/A & N/A \\
\hline \multirow[t]{9}{*}{ Submerged Macrophytes } & Cabomba caroliniana & Pond B & 42,106 & 12.17 & 13.65 & 13.053 & 5 & 0.609 & 0.272 \\
\hline & Myriophyllum spicatum & Par Pond & 7,769 & 0.13 & 0.94 & 0.367 & 29 & 0.206 & 0.038 \\
\hline & Myriophyllum spicatum & L-Lake & 5,600 & 0.02 & 0.08 & 0.056 & 6 & 0.026 & 0.011 \\
\hline & Myriophyllum spicatum & Pond $\mathrm{B}$ & 11,635 & 3.58 & 3.64 & 3.607 & 3 & 0.027 & 0.016 \\
\hline & Myriophyllum spicatum & Pond 5 & 5,611 & 0.028 & 0.189 & 0.101 & 6 & 0.096 & 0.039 \\
\hline & Najas odorata & L-Lake & 4,900 & 0.04 & 0.06 & 0.049 & 3 & 0.007 & 0.004 \\
\hline & Najas minor & Par Pond & 5,413 & 0.21 & 1.3 & 0.655 & 30 & 0.312 & 0.057 \\
\hline & Vallisneria americana & L-Lake & 1,900 & 0.005 & 0.03 & 0.019 & 7 & 0.011 & 0.004 \\
\hline & Vallisneria americana & Par Pond & 1,083 & 0.09 & 0.35 & 0.131 & 24 & 0.058 & 0.012 \\
\hline
\end{tabular}


Table A-2 : Radioactivity and Bioconcentration Factors (BCF) of Cs-137 for Biotic (Bq/L) Components at Selected SRS Impoundments, 1993-1996 (Hinton, 1996).

\begin{tabular}{|c|c|c|c|c|c|c|c|c|c|}
\hline Life Form or Media & Scientific Name & Location & BCF & \multicolumn{6}{|c|}{ Radioactivity (Bq/g or $B q / L)$} \\
\hline Grasses, Sedges, and Rushes & Panicum hemitomon & Par Pond & 1,107 & 0.09 & 0.18 & 0.134 & 12 & 0.028 & 0.008 \\
\hline \multirow[t]{8}{*}{ Emergent Macrophytes } & Pontederia cordata & Pond B & 1,197 & 0.371 & 0.371 & N/A & 1 & N/A & N/A \\
\hline & Pontederia cordata & Par Pond & 421 & 0.05 & 0.051 & 0.051 & 2 & 0.005 & 0.004 \\
\hline & Sagittaria latifolia & L-Lake & 2,200 & 0.002 & 0.05 & 0.022 & 3 & 0.022 & 0.013 \\
\hline & Sagittaria latifolia & Pond 5 & 16,056 & 0.028 & 0.545 & 0.289 & 6 & 0.247 & 0.101 \\
\hline & Sagittaria latifolia & Par Pond & 11,256 & 0.37 & 3.48 & 1.362 & 6 & 1.142 & 0.466 \\
\hline & Typha latifolia & L-Lake & 1,400 & 0.004 & 0.04 & 0.014 & 5 & 0.014 & 0.006 \\
\hline & Typha latifolia & Pond 5 & 2,167 & 0.022 & 0.064 & 0.039 & 6 & 0.021 & 0.009 \\
\hline & Typha latifolia & Par Pond & 421 & 0.02 & 0.09 & 0.051 & 17 & 0.02 & 0.005 \\
\hline \multirow[t]{4}{*}{ Piscivorous Fish } & Micropterus salmoides & Par Pond & 4,050 & 0.16 & 1.26 & 0.49 & 704 & 0.18 & 0.0068 \\
\hline & Micropterus salmoides & L-Lake & 4,000 & 0.01 & 0.11 & 0.04 & 104 & 0.01 & 0.001 \\
\hline & Micropterus salmoides & Pond 5 & 3,333 & 0.04 & 0.09 & 0.06 & 40 & 0.01 & 0.0016 \\
\hline & Micropterus salmoides & Pond B & 13,581 & 0.41 & 7.6 & 4.21 & 127 & 1.12 & 0.0994 \\
\hline \multirow[t]{4}{*}{ Surface Water } & N/A & Par Pond & N/A & 0.08 & 0.2 & 0.121 & 18 & 0.0265 & 0.0062 \\
\hline & $\vdots$ & L-Lake & N/A & 0.01 & 0.01 & N/A & 1 & N/A & N/A \\
\hline & & Pond 5 & N/A & 0.01 & 0.04 & 0.018 & 12 & 0.0088 & 0.0025 \\
\hline & & Pond $\mathrm{B}$ & N/A & 0.31 & 0.31 & N/A & 1 & N/A & $\mathrm{N} / \mathrm{A}$ \\
\hline
\end{tabular}




\section{APPENDIX B}

\section{TERRESTRIAL AND WETLAND BIOCONCENTRATION FACTORS}

The following tables present bioconcentration factors that are specific to the Savannah River Site. The data were obtained from articles distributed internally at the SRS as well as from articles published in technical journals. An attempt was made to collect every available article that contained site specific bioconcentration factors, or data from which bioconcentration factors could be calculated; however, all information was probably not obtained. These tables should provide sufficient information to allow one to decide whether or not a bioconcentration factor is appropriate for the intended use. If more information is needed, the literature article should be reviewed. Figure 1 (Appendix C) is a general site map of the SRS. Each table is divided into the following columns:

1. Medium - Organism or class of organisms for which the bioconcentration factor was calculated

2. Organsim - More specific information (e.g., the scientific name, the common name, the tissue part) about the organism for which the bioconcentration factor was calculated

3. BCF - The bioconcentration factor in scientific notation

4. $\quad \mathrm{N}$ - The sample size - if "comp" is given, then a certain number of samples was collected and composited before analysis, so that only one analysis was performed. If a number is given, the bioconcentration factor was calculated from the mean value of that number of analyses on the medium.

5. General - The general area onsite from which the sample was collected.

6. Specific - More specific information about where the sample was collected

7. ... Radionuclide - The radionuclide for which the bioconcentration factor was calculated.

8. Comments - Additional information about the experimental conditions for the study

9. Reference - The reference from which the data were taken

Other abbreviations that are used in the tables include:

Boiling Sp. - Boiling Springs

Burial Grnd - Burial Ground

Donora St. - Donora Station

E Boundary - Eastern Boundary of SRS, west of Barnwell Nuclear Fuel Plant

FMB - Fourmile Branch

Martin Mill. - Martin Millet

NE SRS - Northeast Savannah River Site

Pat. Mill - Patterson Mill

SRL - Savannah River Laboratory 
Table 1: Bioconcentration factors for SRS flora and fauna by location and radionuclide (Cummins, 1994).

\begin{tabular}{|c|c|c|c|c|c|c|c|c|}
\hline & & & & Location & & & & \\
\hline Medium & Organism & BCF & $\bar{N}$ & General & Spectic & Radionuclide & Conditions & Reference \\
\hline Bahia Grass & Paspalum notatum & $1.20 \mathrm{E}-01$ & & & & Am-241 & Dothan Soil, 100 days after germination, greenhouse & Adriano et al 1980b \\
\hline Bahia Grass & Paspalum notatum & $8.00 \mathrm{E}-02$ & & & & Am-241 & Dothan Soil, 130 days after germination, greenhouse & Adriano et al 1980b \\
\hline Bahia Grass & Paspalum notatum & $5.90 \mathrm{E}-02$ & & & & $\mathrm{Am}-241$ & Dothan Soil, 180 days after germination, greenhouse & Adriano et al $1980 \mathrm{~b}$ \\
\hline Bahia Grass & Paspalum notatum & $4.00 \mathrm{E}-02$ & & & & Am-24! & Troupe Soil, 100 days after germination, greenhouse & Adriano et al 1980b \\
\hline Bahia Grass & Pospalum notatum & $7.50 \mathrm{E}-02$ & & & & $\mathrm{Am} \cdot 241$ & Troupe Soil, 130 days after germination, greenhouse & Adriano et al $1980 \mathrm{~b}$ \\
\hline Bahia Grass & Paspalum notatum & $3.00 \mathrm{E}-02$ & & & & Am-241 & Troupe Soil, 180 days after germination, greenhouse & Adriano et al $1980 \mathrm{~b}$ \\
\hline Pine Tree & Leaves & $1.40 \mathrm{E}-04$ & 12 & SRL & Basin 4 & Am-241 & & Murphy 1992 \\
\hline Pine Tree & Leaves & $2.50 \mathrm{E}-04$ & 16 & SRL & Basin Edge & Am-241 & & Murphy 1992 \\
\hline Pine Tree & Leaves & $2.10 \mathrm{E}-02$ & 12 & SRL & $\operatorname{Basin} 4$ & $\mathrm{Cm}-242,244$ & & Murphy 1992 \\
\hline Pine Tree & Leaves & $5.20 \mathrm{E}-03$ & 16 & SRL & Basin Edge & $\mathrm{Cm}-242,244$ & & Murphy 1992 \\
\hline Bahia Grass & Paspalum notatum & $7.75 \mathrm{E}-03$ & 7 & H Area/ FMB & Floodplain & $\mathrm{Cm} \cdot 244$ & sand $=69 \%$, clay $=20 \%$, greenhouse, ist year & Adriano et. al. 1986 \\
\hline Bahia Grass & Paspalum notatum & $1.15 \mathrm{E}-02$ & 7 & H Area/ FMB & Floodplain & $\mathrm{Cm} \cdot 244$ & sand $=69 \%$, clay $=20 \%$, greenhouse, 4th year & Adriano et. al. 1986 \\
\hline Bahia Grass & Paspalum notatum & $7.50 \mathrm{E}-03$ & 7 & H Area/FMB & Floodplain & $\mathrm{Cm}-244$ & sand $=69 \%$, silt $=11 \%$, clay $=20 \%$, greenhouse & Adriano et. al. $1981 \mathrm{~b}$ \\
\hline Clover & Trifolium repens & $4.99 \mathrm{E}-02$ & 7 & H Area/ FMB & Floodplain & $\mathrm{Cm}-244$ & sand $=69 \%$, clay $=20 \%$, greenhouse, 1 st year & Adriano et. al. 1986 \\
\hline Clover & Trifolium repens & $3.91 \mathrm{E}-02$ & 7 & H Area/ FMB & Floodplain & $\mathrm{Cm}-244$ & sand $=69 \%$, clay $=20 \%$, greenhouse, 4 th year & Adriano et. al. 1986 \\
\hline Clover & Trifolium repens & $4.90 \mathrm{E}-02$ & 7 & HArea/FMB & Floodplain & $\mathrm{Cm}-244$ & $\operatorname{sand}=69 \%$, silt $=11 \%$, clay $=20 \%$, greenhouse & Adriano et. al. $1981 \mathrm{~b}$ \\
\hline Corn & Zea mays, Ear & $3.10 \mathrm{E}-03$ & 7 & H Area/FMB & Floodplain & $\mathrm{Cm}-244$ & sand $=69 \%$, silt $=11 \%$, clay $=20 \%$, greenhouse & Adriano et. al. $1981 \mathrm{~b}$ \\
\hline Corn & Zea mays, Leaves & $2.44 \mathrm{E}-02$ & 7 & H Area/FMB & Floodplain & $\mathrm{Cm}-244$ & sand $=69 \%$, clay $=20 \%$, greenhouse, 1st year & Adriano et. al. 1986 \\
\hline Corn & Zea mays, Leaves & $1.05 E-02$ & 7 & H Areal FMB & Floodplain & $\mathrm{Cm}-244$ & sand $=69 \%$, clay $=20 \%$, greenhouse, 4th year & Adriano et. al. 1986 \\
\hline Corn & Zea mays, Leaves & $2.40 \mathrm{E}-02$ & 7 & H Area/FMB & Floodplain & $\mathrm{Cm}-244$ & sand $=69 \%$, silt $=11 \%$, clay $=20 \%$, greenhouse & Adriano et. al. 1981b \\
\hline Corn & Zea mays, Stalk & $9.70 \mathrm{E}-03$ & 7 & H Area/FMB & Floodplain & $\mathrm{Cm}-244$ & sand $=69 \%$, silt $=11 \%$, clay $=20 \%$, greenhouse & Adriano et. al. 1981b \\
\hline Rice & Belle Patna, foliage & $2.20 \mathrm{E}-03$ & 6 & HARea/FMB & Floodplain & $C m-244$ & silt $=11 \%$, clay $=20 \%$, greenhouse & Adriano et. al. $1981 \mathrm{a}$ \\
\hline Rice & Belle Patna, Grain & $1.70 \mathrm{E}-03$ & 6 & H Area/FMB & Floodplain & $\mathrm{Cm}-244$ & silt $=11 \%$, clay $=20 \%$, greenhouse & Adriano et. al. 1981a \\
\hline Rice & IR-1561, foliage & $2.30 \mathrm{E}-03$ & 6 & H Area/FMB & Floodplain & $\mathrm{Cm} \cdot 244$ & silt=11\%, clay $=20 \%$, greenhouse & Adriano et. al. 1981a \\
\hline Rice & IR-1561, Grain & $1.30 \mathrm{E}-03$ & 6 & H Area/FMB & Floodplain & $\mathrm{Cm}-244$ & silt $=11 \%$, clay $=20 \%$, greenhouse & Adriano et. al. 1981a \\
\hline Rice & Nato, foliage & $2.10 \mathrm{E}-03$ & 6 & HArea/FMB & Floodplain & $\mathrm{Cm} \cdot 244$ & silt $=11 \%$, clay $=20 \%$, greenhouse & Adriano et. al. 1981 a \\
\hline Rice & Nato, Grain & $1.90 \mathrm{E}-03$ & 6 & H Area/FMB & Floodplain & $\mathrm{Cm}-244$ & silt=11\%, clay $=20 \%$, greenhouse & Adriano et, al. 1981a \\
\hline Rice & Starbonnet, foliage & $2.00 \mathrm{E}-03$ & 6 & H Area/FMB & Floodplain & $\mathrm{Cm}-244$ & silt $=11 \%$, clay $=20 \%$, greenhouse & Adriano et. al. $1981 \mathrm{a}$ \\
\hline Rice & Starbonnet, Grain & $4.50 \mathrm{E}-03$ & 6 & HArea/FMB & Floodplain & $\mathrm{Cm}-244$ & silt $=11 \%$, clay $=20 \%$, greenhouse & Adriano et. al. 1981a \\
\hline
\end{tabular}




\begin{tabular}{|c|c|c|c|c|c|c|c|c|}
\hline & & & & Location & & & & \\
\hline Medium & Organism & $\overline{\mathrm{BCF}}$ & $\bar{N}$ & General & Specific & Radionuclide & Conditions & Reference \\
\hline Soybean & Glycine max, Bean & $4.50 \mathrm{E}-03$ & 7 & HArea/FMB & Floodplain & Cm-244 & sand $=69 \%$, silt $=11 \%$, clay $=20 \%$, greenhouse & Adriano et. al. 1981b \\
\hline Soybean & Glycine max, Stem & $1.35 \mathrm{E}-02$ & 7 & HArea/FMB & Floodplain & $\mathrm{Cm}-244$ & sand $=69 \%$, clay $=20 \%$, greenhouse, 1 st year & Adriano et. al. 1986 \\
\hline Soybean & Olycine max, Stem & $2.79 \mathrm{E}-02$ & 7 & H Area/FMB & Floodplain & $\mathrm{Cm}-244$ & sand $=69 \%$, clay $=20 \%$, greenhouse, 4 th year & Adriano et. al. 1986 \\
\hline Soybean & Glycine max, Stem & $1.30 \mathrm{E}-02$ & 7 & H Area/ FMB & Floodplain & $\mathrm{Cm}-244$ & $\operatorname{sand}=69 \%$, silt $=11 \%$, clay $=20 \%$, greenhouse & Adriano et. al. $1981 \mathrm{~b}$ \\
\hline Tree & Maple, sweetgum, and poplar, Bark & $2.10 \mathrm{E}-03$ & 9 & HArea/ FMB & Floodplain & $\mathrm{Cm}-244$ & Field experiment & Pinder et. al. 1984 \\
\hline Tree & Maple, sweetgum, and poplar, Leaves & $7.50 \mathrm{E}-03$ & 9 & H Area/FMB & Floodplain & $\mathrm{Cm} \cdot 244$ & Field experiment & Pinder et. al. 1984 \\
\hline Tree & Maple, sweetgum, and poplar, Wood & $3.60 \mathrm{E}-03$ & 9 & H Area FMB & Floodplain & $\mathrm{Cm}-244$ & Field experiment & Pinder et. al. 1984 \\
\hline Wheat & Triticum aestivum, Grain & $3.30 \mathrm{E}-03$ & 7 & H Area/FMB & Floodplain & $\mathrm{Cm} \cdot 244$ & sand $=69 \%$, silt $=11 \%$, clay $=20 \%$, greenhouse & Adriano et. al. 1981b \\
\hline Wheat & Triticum aestivum, Stem & $3.62 \mathrm{E}-03$ & 7 & H Area/ FMB & Floodplain & $\mathrm{Cm}-244$ & $\operatorname{sand}=69 \%$, clay $=20 \%$, greenhouse, 1st year & Adriano et. al. 1986 \\
\hline Wheat & Triticum aestivum, Stem & $6.88 \mathrm{E}-03$ & 7 & H Area/ FMB & Floodplain & $\mathrm{Cm}-244$ & sand $=69 \%$, clay $=20 \%$, greenhouse, 4th year & Adriano et. al. 1986 \\
\hline Wheat & Triticum aestivum, Stem & $3.50 \mathrm{E}-03$ & 7 & H Area FMB & Floodplain & $\mathrm{Cm}-244$ & sand $=69 \%$, silt $=11 \%$, clay $=20 \%$, greenhouse & Adriano et. al. 1981b \\
\hline Bush Bean & Phaselous vulgaris, young leaves & $2.82 \mathrm{E}+00$ & 4 & & & Co-60 & Sand $=63 \%$, clay $=30 \%$, Dothan Soil, greenhouse & Adriano et. al. 1977 \\
\hline Bush Bean & Phaselous vulgaris, old leaves & $5.20 \mathrm{E}-01$ & 4 & & & Co-60 & Sand $=63 \%$, clay $=30 \%$, Dothan Soil, greenhouse & Adriano et. al. 1977 \\
\hline Bush Bean & Phaselous vulgaris, old leaves & $4.00 \mathrm{E}-01$ & 4 & & & Co-60 & Sand $=82 \%$, clay $=12 \%$, Troupe Soil, greenhouse & Adriano et. al. 1977 \\
\hline Bush Bean & Phaselous.vulgaris, stem & $2.32 \mathrm{E}+00$ & 4 & & & Co-60 & Sand $=63 \%$, clay $=30 \%$, Dothan Soil, greenhouse & Adriano et. al. 1977 \\
\hline Bush Bean & Phaselous vulgaris, stem & $7.93 \mathrm{E}-01$ & 4 & & & Co-60 & Sand $=82 \%$, clay $=12 \%$, Troupe Soil, greenhouse & Adriano et. al. 1977 \\
\hline Bush Bean & Phaselous vulgaris, young leaves & $1.02 \mathrm{E}+00$ & 4 & & & Co-60 & Sand $=82 \%$, clay $=12 \%$, Troupe Soil, greenhouse & Adriano et. al. 1977 \\
\hline Corn & Zea mays, Leaves & $5.63 \mathrm{E}-01$ & 4 & & & Co-60 & Sand $=63 \%$, clay $=30 \%$, Dothan Soil, greenhouse & Adriano et. al. 1977 \\
\hline Corn & Zea mays, Leaves & $2.09 \mathrm{E}-01$ & 4 & & & Co-60 & Sand $=82 \%$, clay $=12 \%$, Troupe Soil, greenhouse & Adriano et. al. 1977 \\
\hline Corn & Zea mays, stem & $2.69 \mathrm{E}-01$ & 4 & & & $\mathrm{Co}-60$ & Sand $=63 \%$, clay $=30 \%$, Dothan Soil, greenhouse & Adriano et. al. 1977 \\
\hline Corn & Zea mays, Stem & $1.27 \mathrm{E}-01$ & 4 & & & Co-60 & Sand $=82 \%$, clay $=12 \%$, Troupe Soil, greenhouse & Adriano et. al. 1977 \\
\hline Pine Tree & Leaves & $6.10 \mathrm{E}-01$ & 12 & SRL & Basin 4 & $\mathrm{Co}-60$ & & Murphy 1992 \\
\hline Pine Tree & Leaves & $1.80 \mathrm{E}-02$ & 16 & SRL & Basin Edge & Co.60 & & Murphy 1992 \\
\hline Alder & Alnus serrulata, leaves & $2.30 \mathrm{E}+00$ & 16 & Steel Creek & Floodplain & Cs-137 & field experiment & Garten et. al. 1975a \\
\hline Alder & Alnus serrulata, roots & $3.20 \mathrm{E}+00$ & 16 & Steel Creek & Floodplain & Cs.137 & field experiment & Garten et. al. 1975a \\
\hline Alder & Alnus serrulata, species mean & $2.10 \mathrm{E}+00$ & 16 & Steel Creek & Floodplain & Cs-137 & field experiment & Garten et. al. 1975a \\
\hline Alder & Alnus serrulata, stem & $9.00 \mathrm{E}-01$ & 16 & Steel Creek & Floodplain & Cs-137 & field experiment & Garten et. al. 1975a \\
\hline Aphids & Homoptera & $6.80 \mathrm{E}-01$ & comp & Steel Creek & Floodplain & Cs-137 & Old-Field Habitat - Homoptera/Araneae & Anderson et. al. 1973 \\
\hline Aphids & Homoptera & $6.70 \mathrm{E}-01$ & comp & Steel Creek & Floodplain & Cs-137 & Old-Field Habitat - Homoptera/Coleoptera & Anderson et. al. 1973 \\
\hline Aphids & Homoptera & $4.30 \mathrm{E}-01$ & comp & Steel Creek & Floodplain & Cs-137 & OId-Field Habitat - Homoptera/Orthoptera & Anderson et. al. 1973 \\
\hline
\end{tabular}




\begin{tabular}{|c|c|c|c|c|c|c|c|c|}
\hline & & & & Location & & & & \\
\hline Medium & Organism & $\overline{\mathrm{BCF}}$ & $\bar{N}$ & General & Specific & Radionuclide & Conditions & Reference \\
\hline Aphids & Homoptera & $2.80 \mathrm{E}-01$ & comp & Steel Creek & Floodplain & Cs-137 & Old-Field Habitat - Homoptera/Andropogon & Anderson et. al. 1973 \\
\hline Aphids & Homoptera & $5.20 \mathrm{E}-01$ & comp & Steel Creek & Floodplain & Cs- 137 & Old-Field Habitat - Homoptera/Alnus & Anderson et. al. 1973 \\
\hline Aphids & Homoptera & $3.30 \mathrm{E}-01$ & comp & Steel Creek & Floodplain & Cs-137 & Old-Field Habitat - Homoptera/Myrica & Anderson et. al. 1973 \\
\hline Aphids & Homoptera & $3.90 \mathrm{E}-01$ & comp & Steel Creek & Floodplain & Cs- 137 & Old-Field Habitat - Homoptera/Salix & Anderson et. al. 1973 \\
\hline Arrowhead & Sagittaria latifolia, leaves & $4.00 \mathrm{E}-01$ & 40 & Beaver Dam & backwater & Cs-137 & Org matter $=15.7 \%$, soil moist $=63.7 \%, 6.4 \mathrm{ppm} \mathrm{K}$ & Garten and Paine 1977 \\
\hline Arrowhead & Sagittaria latifolia, leaves & $7.00 \mathrm{E}+00$ & 40 & Par Pond & West cove & Cs-137 & Org matter $=1.5 \%$, soil moist $=24.5 \%, 0.6 \mathrm{ppm} \mathrm{K}$ & Garten and Paine 1977 \\
\hline Arrowhead & Sagittaria latifolia, leaves & $4.00 \mathrm{E}-01$ & 40 & Pen Branch. & backwater & Cs-137 & Org matter $=42.1 \%$, soil moist $=83.5 \%, 12.6 \mathrm{ppm} \mathrm{K}$ & Garten and Paine 1977 \\
\hline Arrowhead & Sagittaria latifolia, leaves & $7.10 \mathrm{E}+00$ & 40 & Pond C & & Cs- 137 & Org matter $=2.2 \%$, soil moist $=24.3 \%, 1.1 \mathrm{ppm} \mathrm{K}$ & Garten and Paine 1977 \\
\hline Arrowhead & Sagittaria latifolia, leaves & $3.60 \mathrm{E}+00$ & 40 & Steel Creek & & Cs-137 & Org matter $=3.5 \%$, soil moist $=39.8 \%, 2.1 \mathrm{ppm} \bar{K}$ & Garten and Paine 1977 \\
\hline Arrowhead & Sagittaria latifolia, leaves & $4.40 \mathrm{E}+00$ & 40 & Steel Creek & & $\mathrm{Cs}-137$ & Org matter $=3.3 \%$, soil moist. $=37.4 \%, 1.5 \mathrm{ppm} \mathrm{K}$ & Garten and Paine 1977 \\
\hline Arrowhead & Sagittaria latifolia, leaves & $4.50 \mathrm{E}+00$ & 40 & Steel Creek & & $\mathrm{Cs}-137$ & Org matter $=4.7 \%$, soil moist. $=43.1 \%, 1.9 \mathrm{ppm} \mathrm{K}$ & Garten and Paine 1977 \\
\hline Arrowhead & Sagittaria latifolia, leaves & $1.07 \mathrm{E}+01$ & 40 & Steel Creek & & Cs-137 & Org matter $=2.5 \%$, soil moist. $=29.7 \%, 0.9 \mathrm{ppm} \mathrm{K}$ & Garten and Paine 1977 \\
\hline Arrowhead & Sagittaria latifolia, leaves & $7.90 \mathrm{E}+00$ & 40 & Steel Creek & & Cs-137 & Org matter $=4.1 \%$, soil moist. $=39.3 \%, 2.1 \mathrm{ppm} \mathrm{K}$ & Garten and Paine 1977 \\
\hline Arrowhead & Sagittaria latifolia, leaves & $3.30 \mathrm{E}+00$ & 40 & Steel Creek & & Cs-137 & Org matter $=4.0 \%$, soil moist. $=41.4 \%, 1.7 \mathrm{ppm} \mathrm{K}$ & Garten and Paine 1977 \\
\hline Arrowhead & Sagittaria latifolia, leaves & $2.08 \mathrm{E}+01$ & 56 & Steel Creek & deita & Cs-137 & & Sharitz et. al. 1975 \\
\hline Arrowhead & Saginaria latifolia, leaves & $6.50 \mathrm{E}-01$ & 13 & Steel Creek & delta & Cs-137 & & Sharitz et. al. 1975 \\
\hline Anowhead & Sagittaria latifolia, roots & $1.37 \mathrm{E}+01$ & 56 & Steel Creek & delta & Cs.137 & & Sharitz et. al. 1975 \\
\hline Arrowhead & Sagitta ria latifolia, roots & $5.40 \mathrm{E}-01$ & 13 & Steel Creek & delta & Cs-137 & & Sharitz et. al. 1975 \\
\hline Bahia Grass & Paspalum notatum & $5.20 \mathrm{E}+00$ & 7 & H Area/FMB & Floodplain & Cs-137 & silt $=11 \%$, clay $=20 \%$, greenhouse, 1 st year & Adriano et. al. 1984 \\
\hline Bahia Grass & Paspalum notatum & $7.56 \mathrm{E}+00$ & 7 & H Area/FMB & Floodplain & Cs-137 & silt $=11 \%$, clay $=20 \%$, greenhouse, 2 nd year & Adriano et. al. 1984 \\
\hline Bahia Grass & Paspalum notatum & $? .59 \mathrm{E}+00$ & 7 & H Area/FMB & Floodplain & Cs-137 & silt $=11 \%$, clay $=20 \%$, greenhouse, 3 rd year & Adriano et. al. 1984 \\
\hline Bahia Grass & Paspalum notatum & $4.61 \mathrm{E}+00$ & 7 & H Area/FMB & Floodplain & Cs-137 & silt $=11 \%$, clay $=20 \%$, greenhouse, 4 th year & Adriano et. al. 1984 \\
\hline Bahia Grass & Paspalum notatum & $1.60 \mathrm{E}+00$ & 7 & H Area/ FMB & Floodplain & Cs-137 & silt $=11 \%$, clay $=20 \%$, greenhouse, 5 h year & Adriano et al. 1984 \\
\hline Beetles & Coleoptera & $4.20 \mathrm{E}-01$ & comp & Steel Creek & Floodplain & Cs-137 & Old-Field Habitat - Coleoptera/Salix & Anderson et. al: 1973 \\
\hline Beetles & Coleoptera & $9.30 \mathrm{E}-01$ & comp & Steel Creek & Floodplain & Cs.137 & Old-Field Habitat - Coleoptera/Araneae & Anderson et: al. 1973 \\
\hline Beetles & Coleoptera & $4.10 \bar{E}-01$ & comp & Steel Creek & Floodplain & Cs-137 & Old-Field Habitat - Coleoptera/Andropogon & Anderson et. al. 1973 \\
\hline Beetles & Coleoptera & $1.20 \mathrm{E}+00$ & comp & Steel Creek & Floodplain & Cs-137 & Old-Field Habitat - Coleoptera/Homoptera & Anderson et. al. 1973 \\
\hline Beetles & Coleoptera & $9.60 \mathrm{E}-0 \mathrm{I}$ & comp & Steel Creek & Floodplain & Cs-137 & Old-Field Habitat - Coleoptera/Alnus & Anderson et. al. 1973 \\
\hline Beetles & Coleoptera & $4.90 \mathrm{E}-01$ & comp & Steel Creek & Floodplain & Cs-137 & Old-Field Habitat - Coleoptera/Myrica & Anderson et. al. 1973 \\
\hline Beetles & Coleoptera & $5.50 \mathrm{E}-01$ & comp & Steel Creek & Floodplain & Cs-137 & Old-Field Habitat - Coleoptera/Orthoptera & Anderson et. al. 1973 \\
\hline Clover & Trifolium repens & $1.30 \mathrm{E}+00$ & 7 & H Area/FMB & Floodplain & Cs-137 & silt $=11 \%$, clay $=20 \%$, greenhouse, 1 st year & Adriano et. al. 1984 \\
\hline
\end{tabular}




\begin{tabular}{|c|c|c|c|c|c|c|c|c|}
\hline & & & & Location & & & & \\
\hline Medium & Organism & $\overline{B C F}$ & $\overline{\mathbf{N}}$ & General & Specific & Radionuclide & Conditions & Reference \\
\hline Clover & Trifolium repens & $9.30 \mathrm{E}-01$ & 7 & HArea/FMB & Floodplain & Cs-137 & silt $=11 \%$, clay $=20 \%$, greenhouse, 2 nd year & Adriano et. al. 1984 \\
\hline Clover & Trifolium repens & $8.00 \mathrm{E}-01$ & 7 & HArea/FMB & Floodplain & Cs-137 & silt $=11 \%$, clay $=20 \%$, greenhouse, 3rd year & Adriano et. al. 1984 \\
\hline Corn & Grain & $1.00 \mathrm{E}-02$ & 13 & Burial Gind & & Cs-137 & Roots did not penetrate waste & Gay 1982 \\
\hline Corn & Leaves & $6.20 \mathrm{E}-02$ & 13 & Burial Gmd & & Cs-137 & Roots did not penetrate waste & Gay 1982 \\
\hline Corn & Zea mays, Leaves & $2.53 \mathrm{E}+00$ & 7 & HArea/FMB & Floodplain & Cs-137 & silt $=11 \%$, clay $=20 \%$, greenhouse, Ist year & Adriano et. al. 1984 \\
\hline Corn & Zea mays, Leaves & $7.40 \mathrm{E}-01$ & 7 & HArea/FMB & Floodplain & Cs-137 & silt $=11 \%$, clay $=20 \%$, greenhouse, 2 nd year & Adriano et. al. 1984 \\
\hline Corn & Zea mays, Leaves & $7.30 \mathrm{E}-01$ & 7 & HArea/FMB & Floodplain & Cs-137 & silt $=11 \%$, clay $=20 \%$, greenhouse, 3rd year & Adriano et. al. 1984 \\
\hline Corn & Zza mays, Leaves & $2.40 \mathrm{E}-01$ & 7 & H Area/ FMB & Floodplain & Cs-137 & silt $=11 \%$, clay $=20 \%$, greenhouse, 4 th year & Adriano et. al. 1984 \\
\hline Corn & Zea mays, Leaves & $5.40 \mathrm{E}-01$ & 7 & H Area/FMB & Floodplain & Cs-137 & silt $=11 \%$, clay $=20 \%$, greenhouse, 5 th year & Adriano et. al. 1984 \\
\hline Corn & Zea mays, Stems & $7.90 \mathrm{E}-01$ & 7 & HArea/FMB & Floodplain & Cs-137 & silt= $11 \%$, clay $=20 \%$, greenhouse, 1 st year & Adriano et. al. 1984 \\
\hline Corn & Zea mays, Stems & $2.80 \mathrm{E}-01$ & 7 & HArea/FMB & Floodplain & Cs-137 & silt $=11 \%$, clay $=20 \%$, greenhouse, 2 nd year & Adriano et. al. 1984 \\
\hline Corn & Zea mays, Stems & $3.80 \mathrm{E}-01$ & 7 & HArea/FMB & Floodplain & Cs-137 & silt $=11 \%$, clay $=20 \%$, greenhouse, 3 rd year & Adriano et. al. 1984 \\
\hline Corn & Zea mays, Stems & $1.70 \mathrm{E}-01$ & 7 & HArea/FMB & Floodplain & Cs-137 & silt $=11 \%$, clay $=20 \%$, greenhouse, 4 th year & Adriano et. al. 1984 \\
\hline Corn & Zea mays, Stems & $2.30 \mathrm{E}-01$ & 7 & HArea/FMB & Floodplain & Cs-137 & silt $=11 \%$, clay $=20 \%$, greenhouse, 5th year & Adriano et. al. 1984 \\
\hline Crickets & Orthoptera & $6.60 \mathrm{E}-01$ & comp & Steel Creek & Floodplain & Cs-137 & Old-Field Habitat - Orthoptera/Andropogon & Anderson et. al. 1973 \\
\hline Crickets & Orthoptera & $1.30 \mathrm{E}+00$ & comp & Steel Creek & Floodplain & Cs-137 & Old-Field Habitat - Orthoptera/Alnus & Anderson et. al. 1973 \\
\hline Crickets & Orthoptera & $6.90 \mathrm{E}-01$ & comp & Steel Creek & Floodplain & Cs-137 & Old-Field Habitat - Orthoptera/Myrica & Anderson et. al. 1973 \\
\hline Crickets & Orthoptera & $8.40 \mathrm{E}-01$ & comp & Steel Creek & Floodplain & Cs-137 & Old-Field Habitat - Orthoptera/Salix & Anderson et. al. 1973 \\
\hline Crickets & Orthoptera & $1.60 \mathrm{E}+\infty 0$ & comp & Steel Creek & Floodplain & Cs-137 & Old-Field Habitat - Orthoptera/Araneae & Anderson et. al. 1973 \\
\hline Crickets & Orthoptera & $1.60 \mathrm{E}+\infty 0$ & comp & Steel Creek & Floodplain & Cs-137 & Old-Field Habitat - Orthoptera/Coleoptera & Anderson et. al. 1973 \\
\hline Crickets & Orthoptera & $2.10 \mathrm{E}+00$ & comp & Steel Creek & Floodplain & Cs-137 & Old-Field Habitat - Orthoptera/Homoptera & Anderson et. al. 1973 \\
\hline Dry forage & & $3.00 \mathrm{E}+00$ & & Par Pond & & Cs-137 & & Whicker et. al. 1993 \\
\hline Fresh vegetables & & $9.00 \mathrm{E}-01$ & & Par Pond & & Cs-137 & & Whicker et. al. 1993 \\
\hline Fungi & Agaric & $1.34 \mathrm{E}+01$ & 22 & LTR & \begin{tabular}{|c|c|c|} 
Pat. Mill \\
\end{tabular} & Cs-137 & All substrates & Hay 1977 \\
\hline Fungi & Agaric & $9.30 \mathrm{E}+00$ & 21 & LTR & $\begin{array}{l}\text { Martin- } \\
\text { Mill. }\end{array}$ & Cs-137 & All substrates & Hay 1977 \\
\hline Fungi & Agaric & $9.60 \mathrm{E}+00$ & 4 & $\overline{\mathrm{LTR}}$ & Pat. Mill & Cs-137 & Standing stumps & Hay 1977 \\
\hline Fungi & Agaric & $1.84 \mathrm{E}+01$ & 3 & LTR & $\begin{array}{l}\text { Martin- } \\
\text { Mill. }\end{array}$ & Cs-137 & Standing stumps & Hay 1977 \\
\hline Fungi & Agaric & $1.50 E+01$ & 12 & LTR & Pat, Mill & Cs-137 & Prone logs & Hay 1977 \\
\hline Fungi & Agaric & $6.70 \mathrm{E}+00$ & 10 & $\overline{\mathrm{LTR}}$ & $\begin{array}{l}\text { Martin- } \\
\text { Mill. }\end{array}$ & Cs- 137 & Prone logs & Hay 1977 \\
\hline Fungi & $\begin{array}{ll}\text { Agaric } \\
\text {. }\end{array}$ & $1.34 \mathrm{E}+01$ & 3 & LTR & Pat. Mill & Cs-137 & Fallen branch & Hay 1977 \\
\hline Fungi & Agaric & $1.00 \mathrm{E}+01$ & 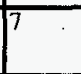 & LTR & $\begin{array}{l}\text { Martin- } \\
\text { Mill. }\end{array}$ & Cs-137 & Fallen branch & Hay 1977 \\
\hline Fungi & Agaric & $1.04 E+01$ & 3 & LTR & Pat. Mill & Cs-137 & Soil/Litter & Hay 1977 \\
\hline
\end{tabular}




\begin{tabular}{|c|c|c|c|c|c|c|c|c|}
\hline & & & & Locati & & & & \\
\hline Medium & Organism & $\overline{\mathrm{BCF}}$ & $\bar{N}$ & General & Specific & Radionuclide & Conditions & Reference \\
\hline Fungi & Agaric & $1.15 E+01$ & 1 & LTR & $\begin{array}{l}\text { Martin- } \\
\text { Mill. }\end{array}$ & Cs-137 & Soil/Litter & Hay 1977 \\
\hline Fungi & Bracket & $8.90 \mathrm{E}+00$ & 48 & $\overline{\mathrm{LTR}}$ & Pat. Mill & Cs-137 & All substrates & Hay 1977 \\
\hline Fungi & Bracket & $7.40 \mathrm{E}+00$ & 50 & LTR & $\begin{array}{l}\text { Martin- } \\
\text { Mill. }\end{array}$ & Cs-137 & All substrates & Hay 1977 \\
\hline Fungi & Bracket & $7.40 \mathrm{E}+00$ & 13 & LTR & Pat. Mill & Cs-137 & Standing stumps substtates & Hay 1977 \\
\hline Fungi & Bracket & $6.40 \mathrm{E}+00$ & 17 & LTR & $\begin{array}{l}\text { Martin- } \\
\text { Mill. }\end{array}$ & Cs-137 & Standing sturnps substtates & Hay 1977 \\
\hline Fungi & Bracket & $1.13 \mathrm{E}+01$ & 17 & LTR & Pat. Mill & Cs- 137 & Prone logs substraces & Hay 1977 \\
\hline Fungi & Bracket & $4.80 \mathrm{E}+00$ & 10 & LTR & $\begin{array}{l}\text { Martin- } \\
\text { Mill. }\end{array}$ & $\mathrm{Cs}-137$ & Prone logs substtates & Hay 1977 \\
\hline Fungi & Bracket & $7.50 \mathrm{E}+00$ & 18 & LTR & Pat: Mill & Cs-137 & Fallen branch substtates & Hay 1977 \\
\hline Fungi & Bracket & $1.15 \mathrm{E}+01$ & 23 & LTR & $\begin{array}{l}\text { Martin- } \\
\text { Mill. }\end{array}$ & Cs-137 & Fallen branch substtates & Hay 1977 \\
\hline Fungi & Total & $1.01 \mathrm{E}+01$ & 70 & LTR & Pat. Mill & Cs-137 & All substrates & Hay 1977 \\
\hline Fungi & Total & $8.00 \mathrm{E}+00$ & 71 & LTR & $\begin{array}{l}\text { Martin- } \\
\text { Mill. }\end{array}$ & Cs-137 & All substrates & Hay 1977 \\
\hline Myrtle & Myrica cerifera, leaves & $7.10 \mathrm{E}+00$ & 13 & Steel Creek & Floodplain & Cs-137 & field experiment & Garten et. al. 1975a \\
\hline Myrtle & Myrica cerifera, roots & $7.60 \mathrm{E}+00$ & 13 & Steel Creek & Floodplain & Cs-137 & field experiment & Garten et. al. 1975a \\
\hline Myrtle & Myrica cerifera, species mean & $6.20 \mathrm{E}+00$ & 13 & Steel Creek & Floodplain & Cs-137 & field experiment & Garten et. 2l. 1975a \\
\hline Myrtle & Myrica cerifera, stems & $3.80 \mathrm{E}+00$ & 13 & Steel Creek & Floodplain & Cs-137 & field experiment & Garten et. al. 1975a \\
\hline Pine Tree & Leaves & $2.37 \mathrm{E}+00$ & 12 & SRL & Basin 4 & Cs-137 & & Murphy 1992 \\
\hline Pine Tree & Leaves & $5.20 \mathrm{E}-03$ & 16 & SRL & Basin Edge & Cs-137 & & Murphy 1992 \\
\hline Red Maple & Acer rubrum, leaves & $7.3 \mathrm{E}-01$ & comp & LTR & Boiling Sp. & Cs-137 & $30 \mathrm{~m}$ transcet & Ragsdale and Shure 1973 \\
\hline Red Maple & Acer rubrum, leaves & $2.0 \mathrm{E}-01$ & comp & LTR & Boiling Sp. & Cs-137 & $60 \mathrm{~m}$ transect & Ragsdale and Shure 1973 \\
\hline Red Maple & Acer rubrum, leaves & $2.1 \mathrm{E}+00$ & comp & LTR & Boiling Sp. & Cs-137 & $90 \mathrm{~m}$ transect & Ragsdale and Shure 1973 \\
\hline Red Maple & Acer rubrum, leaves & $3.47 \mathrm{E}+00$ & comp & LTR & Donora St. & Cs-137 & $30 \mathrm{~m}$ transcet & Ragsdale and Shure 1973 \\
\hline Red Maple & Acer rubrum, leaves & $1.2 \mathrm{E}+00$ & comp & LTR & Donora St. & $\overline{C s-137}$ & $60 \mathrm{~m}$ transect & Ragsdale and Shure 1973 \\
\hline Red Maple & Acer rubrum, leaves & $5.45 \mathrm{E}+00$ & comp & LTR & Donora St. & Cs-137 & $90 \mathrm{~m}$ transect & Ragsdale and Shure 1973 \\
\hline Red Maple & Acer rubrum, leaves & $1.6 \mathrm{E}-01$ & comp & LTR & Martin-Mill & Cs. 137 & $30 \mathrm{~m}$ transcet & Ragsdale and Shure 1973 \\
\hline Red Maple & Acer rubrum, leaves & $1.7 \mathrm{E}-01$ & comp & LTR & Martin-Mil & Cs-137 & $60 \mathrm{~m}$ transect & Ragsdale and Shure 1973 \\
\hline Red Maple & Acer rubrum, leaves & $5.7 \mathrm{E}-01$ & comp & LTR & Martin-Mil & Cs-137 & $90 \mathrm{~m}$ transect & Ragsdale and Shure 1973 \\
\hline Red Maple & Acer rubrum, roots & $8.5 \mathrm{E}-01$ & comp & LTR & Boilling Sp. & Cs-137 & $30 \mathrm{~m}$ transcet & Ragsdale and Shure 1973 \\
\hline Red Maple & Acer rubrum, roots & $1.6 \mathrm{E}+00$ & comp & $\overline{\text { LTR }}$ & Boiling Sp. & Cs-137 & $60 \mathrm{~m}$ transect & Ragsdale and Shure 1973 \\
\hline Red Maple & Acer rubrum, roots & $2.1 \mathrm{E}+00$ & comp & LTR & Boiling Sp. & Cs-137 & $90 \mathrm{~m}$ transect & Ragsdale and Shure 1973 \\
\hline Red Maple & Acer rubrum, roots & $8.3 \mathrm{E}+00$ & comp & LTR & Donora St. & Cs.137 & $30 \mathrm{~m}$ transcet & Ragsdale and Shure 1973 \\
\hline Red Maple & Acer rubrum, roots & $2.3 \mathrm{E}+00$ & comp & $\overline{L T R}$ & Donora St. & Cs-137 & $60 \mathrm{~m}$ transect & Ragsdale and Shure 1973 \\
\hline Red Maple & Acer rubrum, roots & $7.6 \mathrm{E}+00$ & comp & LTR & Donora St. & Cs-137 & $90 \mathrm{~m}$ transect & Ragsdale and Shure 1973 \\
\hline
\end{tabular}




\begin{tabular}{|c|c|c|c|c|c|c|c|c|}
\hline & & & & Location & & & & \\
\hline Medium & Organism & $\overline{\mathrm{BCF}}$ & $\bar{N}$ & General & Specific & Radionuclide & Conditions & Reference \\
\hline Red Maple & Acer rubrum, roots & $3.0 \mathrm{E}-01$ & comp & LTR & Martin-Mill & Cs- 137 & $30 \mathrm{~m}$ transcet & Ragsdale and Shure 1973 \\
\hline Red Maple & Acer rubrum, roots & $3.0 \mathrm{E}-01$ & comp & LTR & Martin-Mil & Cs-137 & $60 \mathrm{~m}$ transect & Ragsdale and Shure 1973 \\
\hline Red Maple & Acer rubrum, roots & $9.0 \mathrm{E}-01$ & comp & LTR & Martin-Mil & Cs-137 & $90 \mathrm{~m}$ transect & Ragsdale and Shure 1973 \\
\hline Red Maple & Acer rubrum, young roots & $1.43 \mathrm{E}+00$ & comp. & LTR & Boiling Sp. & Cs-137 & $30 \mathrm{~m}$ transcet & Ragsdale and Shure 1973 \\
\hline Red Maple & Acer rubrum, young roots & $2.29 \mathrm{E}+00$ & comp & LTR & Boiling Sp. & $\mathrm{Cs} \cdot 137$ & $60 \mathrm{~m}$ transect & Ragsdale and Shure 1973 \\
\hline Red Maple & Acer rubrum, young roots & $4.03 \mathrm{E}+00$ & comp & LTR & Boiling Sp. & Cs-137 & $90 \mathrm{~m}$ transect & Ragsdale and Shure 1973 \\
\hline Red Maple & Acer rubrum, young roots & $1.54 \mathrm{E}+01$ & comp & LTR & Donora St. & Cs- 137 & $30 \mathrm{~m}$ transcet & Ragsdale and Shure 1973 \\
\hline Red Maple & Acer rubrum, young roots & $4.43 \mathrm{E}+00$ & comp & LTR & Donora St. & Cs-137 & $60 \mathrm{~m}$ transect & Ragsdale and Shure 1973 \\
\hline Red Maple & Acer rubrum, young roots & $1.31 \mathrm{E}+01$ & comp & LTR & Donora St. & Cs-137 & $90 \mathrm{~m}$ transect & Ragsdale and Shure 1973 \\
\hline Red Maple & Acer rubrum, young roots & $6.4 \mathrm{E}-01$ & comp & LTR & Martin-Mill & Cs-137 & $30 \mathrm{~m}$ transcet & Ragsdale and Shure 1973 \\
\hline Red Maple & Acer rubrum, young roots & $6.1 \mathrm{E}-01$ & comp & LTR & Martin-Mil & Cs-137 & $60 \mathrm{~m}$ transect & Ragsdale and Shure 1973 \\
\hline Red Maple & Acer rubrum, young roots & $1.65 \mathrm{E}+00$ & comp & LTR & Martin-Mil & Cs-137 & $90 \mathrm{~m}$ transect & Ragsdale and Shure 1973 \\
\hline Rice & Belle Patna, foliage & $5.30 \mathrm{E}-01$ & 6 & HArea/FMB & Floodplain & Cs- 137 & silt $=11 \%$, clay $=20 \%$, greenhouse & Adriano et. al. 1981a \\
\hline Rice & Belle Patna, Grain & $3.60 \mathrm{E}-01$ & 6 & H Area/ FMB & Floodplain & Cs-137 & silt $=11 \%$, clay $=20 \%$, greenhouse & Adriano et. al. 1981a \\
\hline Rice & IR-1561, foliage & $9.60 \mathrm{E}-01$ & 6 & H Area/ FMB & Floodplain & Cs-137 & silt $=11 \%$, clay $=20 \%$, greenhouse & Adriano et. al. 1981a \\
\hline$\overline{R i c e}$ & IR-1561, Grain & $6.10 \mathrm{E}-01$ & 6 & H Area/FMB & Floodplain & Cs-137 & silt $=11 \%$, clay $=20 \%$, greenhouse & Adriano et. al. 1981a \\
\hline Rice & Nato, foliage & $7.00 \mathrm{E}-01$ & 6 & H Area/ FMB & Floodplain & Cs-137 & silt $=11 \%$, clay $=20 \%$, greenhouse & Adriano et. al. 1981a \\
\hline Rice & Nato, Grain & $4.60 \mathrm{E}-01$ & 6 & H Area/FMB & Floodplain & Cs-137 & silt $=11 \%$, clay $=20 \%$, greenhouse & Adriano et. al. 1981a \\
\hline Rice & Starbonnet, foliage & $7.10 \mathrm{E}-01$ & 6 & HArea/FMB & Floodplain & Cs-137 & silt $=11 \%$, clay $=20 \%$, greenhouse & Adriano et. al. 1981a \\
\hline Rice & Starbonnet, Grain & $7.00 \mathrm{E}-01$ & 6 & H Area/ FMB & Floodplain & Cs-137 & silt $=11 \%$, clay $=20 \%$, greenhouse & Adriano et. al. 1981a \\
\hline Smartweed & Polygonum punctatum & $6.30 \mathrm{E}-01$ & & LTR & & Cs-137 & & Gladden 1979 \\
\hline Smartweed & Polygonum punctatum & $9.20 \mathrm{E}-01$ & & LTR & & Cs-137 & & Gladden 1979 \\
\hline Smartweed & Polygonum punctafum, Leaves & $1.18 \mathrm{E}+01$ & 18 & Steel Creek & delta & Cs- 137 & Soil $<100 \mathrm{pCi} / \mathrm{g} \mathrm{Cs}-137$ & Sharitz et. al. 1975 \\
\hline Smartweed & Polygonum punctatum, Leaves & $6.00 \mathrm{E}-01$ & 102 & Steel Creek & delta & Cs-137 & Soil $>100 \mathrm{pCi} / \mathrm{g}$ Cs-137 & Sharitz et. al. 1975 \\
\hline Smartweed & Polygonum punctasum, Roots & $2.79 \mathrm{E}+01$ & 18 & Steel Creek & delta & Cs- 137 & Soil < $100 \mathrm{pCi} / \mathrm{g} \mathrm{Cs}-137$ & Sharitz et. al. 1975 \\
\hline Smartweed & Polygonum punctatum, Roots & $8.40 \mathrm{E}-01$ & 102 & Steel Creek & delta & Cs.137 & Soil $>100 \mathrm{pCi} / \mathrm{g} \mathrm{Cs}-137$ & Sharitz et. al. 1975 \\
\hline Smartweed & Polygonum punctatum, Stems & $1.22 \mathrm{E}+01$ & 18 & Steel Creek & delta & Cs-137 & Soil $<100 \mathrm{pCi} / \mathrm{g} \mathrm{Cs}-137$ & Sharitz et. al. 1975 \\
\hline Smartweed & Polygonum punctatum, Stems & $3.90 \mathrm{E}-01$ & 102 & Steel Creek & delta & Cs-137 & Soil >100 pCi/g Cs-137 & Sharitz et. al. 1975 \\
\hline Snakes & & $2.94 \mathrm{E}+00$ & & & & Cs-137 & snakes/small mammals & Brisbin et al. 1974 \\
\hline Soybeans & Glycine max, Beans & $1.66 \mathrm{E}+00$ & 10 & Burial Gnd & & Cs-137 & Roots did not penetrate waste & Gay 1982 \\
\hline Soybeans & Glycine max, Beans & $7.00 \mathrm{E}-01$ & 7 & HArea/FMB & Floodplain & Cs-137 & silt $=11 \%$, clay $=20 \%$, greenhouse, 2 nd year & Adriano et. al. 1984 \\
\hline Soybeans & Glycine max, Beans & $5.90 \mathrm{E}-01$ & 7 & H Area/FMB & Floodplain & Cs-137 & silt $=11 \%$, clay $=20 \%$, greenhouse, 3 rd year & Adriano et. al. 1984 \\
\hline Soybeans & Glycine max, Beans & $2.90 \mathrm{E}-01$ & 7 & HArea/FMB & Floodplain & Cs-137 & silt $=11 \%$, clay $=20 \%$, greenhouse, 4 th year & Adriano et. al. 1984 \\
\hline Soybeans & Glycine max, Beans & $2.60 \mathrm{E}-01$ & 7 & H Area/FMB & Floodplain & Cs-137 & silt $=11 \%$, clay $=20 \%$, greenhouse, 5 th year & Adriano et. al. 1984 \\
\hline Soybeans & Glycine max, Stems & $1.50 \mathrm{E}-01$ & 7 & H Area/FMB & Floodplain & Cs-137 & silt $=11 \%$, clay $=20 \%$, greenhouse, 1st year & Adriano et. al. 1984 \\
\hline
\end{tabular}




\begin{tabular}{|c|c|c|c|c|c|c|c|c|}
\hline & & & & Location & & & & \\
\hline Medium & Organism & $\overline{\mathrm{BCF}}$ & $\mathbf{N}$ & General & Specific & Radionuclide & Conditions & Reference \\
\hline Soybeans & Glycine max, Stems & $2.80 \mathrm{E}-01$ & 7 & H Area/FMB & Floodplain & Cs-137 & silt $=11 \%$, clay $=20 \%$, greenhouse, 2nd year & Adriano et. al. 1984 \\
\hline Soybeans & Glycine max, Stems & $3.70 \mathrm{E}-01$ & 7 & H Area/ FMB & Floodplain & Cs-137 & silt $=11 \%$, clay $=20 \%$, greenhouse, 3rd year & Adriano et. al. 1984 \\
\hline Soybeans & Glycine max, Stems & $1.40 \mathrm{E}-01$ & 7 & H Area/ FMB & Floodplain & Cs-137 & silt $=11 \%$, clay $=20 \%$, greenhouse, 4th year & Adriano et. al. 1984 \\
\hline Soybeans & Glycine max, Stems & $1.70 \mathrm{E}-01$ & 7 & H Area/FMB & Floodplain & Cs-137 & silt $=11 \%$, clay $=20 \%$, greenhouse, 5 th year & Adriano et. al. 1984 \\
\hline Spiders & Araneae & $9.20 \mathrm{E}-01$ & comp & Steel Creek & Floodplain & Cs-137 & Old-Field Habitat - Araneae/Alnus & Anderson et. al. 1973 \\
\hline Spiders & Araneae & $4.10 \mathrm{E}-01$ & comp & Steel Creek & Floodplain & Cs-137 & Old-Field Habitat - Araneae/Andropogon & Anderson et. al. 1973 \\
\hline Spiders & Araneae & $4.50 \mathrm{E}-01$ & comp & Steel Creek & Floodplain & Cs-137 & Old-Field Habitat - Araneae/Myrica & Anderson et. al. 1973 \\
\hline Spiders & Araneae & $1.30 \mathrm{E}+00$ & comp & Steel Creek & Floodplain & Cs-137 & Old-Field Habitat - Araneae/Homoptera & Anderson et. al. 1973 \\
\hline Spiders & Araneae & $5.00 \mathrm{E} \cdot 01$ & comp & Steel Creek & Floodplain & Cs-137 & Old-Field Habitat - Araneae/Salix & Anderson et. al. 1973 \\
\hline Spiders & Araneae & $6.00 \mathrm{E}-01$ & comp & Steel Creek & Floodplain & Cs-137 & Old-Field Habitat - Araneae/Orthoptera & Anderson et. al. 1973 \\
\hline Spiders & Araneae & $9.90 \mathrm{E}-01$ & comp & Steel Creek & Floodplain & Cs-137 & Old-Field Habitat - Araneae/Coleoptera & Anderson et. al. 1973 \\
\hline Tree & Maple, sweetgum, and poplar, Bark & $3.90 \mathrm{E}-02$ & 9 & H Area/FMB & Floodplain & Cs-137 & Field experiment & Pinder et. al. 1984 \\
\hline Tree & Maple, sweetgum, and poplar, Leaves & $2.70 \mathrm{E}-01$ & 9 & H Area/FMB & Floodplain & Cs-137 & Field experiment & Pinder et. al. 1984 \\
\hline Tree & Maple, sweetgum, and poplar, Wood & $1.10 \mathrm{E}-01$ & 9 & HArea/ FMB & Floodplain & Cs-137 & Field experiment & Pinder et, al. 1984 \\
\hline Turkey Oak & Quercus laevis, leaves & $7.9 \mathrm{E}+00$ & 4 & E Boundary & $0-15 \mathrm{~cm}$ & Cs-137 & Sandhills community, sand $=91 \%$, clay $=3$, silt $=6$ & Croom 1978 \\
\hline Turkey Oak & Quercus laevis, leaves & $1.29 \mathrm{E}+01$ & 4 & E Boundary & $0-25 \mathrm{~cm}$ & Cs-137 & Sandhills community, sand $=91 \%$, clay $=3$, silt $=$ & Croom 1978 \\
\hline Turkey Oak & Quercus laevis, leaves & $2.57 \mathrm{E}+01$ & 4 & E Boundary & $5-25 \mathrm{~cm}$ & Cs-137 & Sandhills community, sand $=91 \%$, clay $=3$, silt $=6$ & Croom 1978 \\
\hline Water Tupelo & Nyssa aquatica, Leaves & $8.50 \mathrm{E}-01$ & 15 & & & Cs-137 & inundated soil, greenhouse & McLeod and Dawson 1980 \\
\hline Water Tupelo & Nyssa aquatica, Leaves & $4.10 \mathrm{E}-01$ & 15 & & & Cs-137 & unsaturated soil, greenhouse & McLeod and Dawson 1980 \\
\hline Water Tupelo & Nyssa aquatica, Root & $7.00 \mathrm{E}+00$ & 15 & & & Cs-137 & inundated soil, greenhouse & McLeod and Dawson 1980 \\
\hline Water Tupelo & Nyssa aquatica, Root & $3.20 \mathrm{E}+00$ & 15 & & & Cs-137 & unsaturated soil, greenhouse & McLeod and Dawson 1980 \\
\hline Water Tupelo & Nyssa aquatica, Stem & $7.20 \mathrm{E}-01$ & 15 & & & $\mathrm{Cs}-137$ & inundated soil, greenhouse & McLeod and Dawson 1980 \\
\hline Water Tupelo & Nyssa aquatica, Stem & $4.00 E+00$ & 15 & & & Cs-137 & unsaturated soil, greenhouse & McLeod and Dawson 1980 \\
\hline Wheat & Triticum aestivum, Grain & $1.80 \mathrm{E}-01$ & 7 & H Area/ FMB & Floodplain & Cs-137 & silt $=11 \%$, clay $=20 \%$, greenhouse, 2 nd year & Adriano et. al. 1984 \\
\hline Wheat & Triticum aestivum, Grain & $1.00 \mathrm{E}-01$ & 7 & H Area/FMB & Floodplain & Cs-137 & silt $=11 \%$, clay $=20 \%$, greenhouse, 3 rd year & Adriano et. al. 1984 \\
\hline Wheat & Triticum aestivum, Grain & $6.00 \mathrm{E}-02$ & 7 & H Area/ FMB & Floodplain & Cs-137 & silt $=11 \%$, clay $=20 \%$, greenhouse, 4th year & Adriano et. al. 1984 \\
\hline Wheat & Triticum aestivum, Grain & $7.00 \mathrm{E}-02$ & 7 & HArea/FMB & Floodplain & Cs-137 & silt $=11 \%$, clay $=20 \%$, greenhouse, 5 th year & Adriano et. al. 1984 \\
\hline White Tailed Deer & Odocoileus virginianus, Muscle & $3.80 \mathrm{E}-01$ & 562 & & & Cs-137 & muscle (wet)/Rumen contents (dry) & Haselow 1991 \\
\hline White Tailed Deer & Odocoileus virginianus, Muscle & $6.80 \mathrm{E}-01$ & & & & Cs-137 & muscle (wet)/Rumen contents (dry) & Brisbin and Smith 1975 \\
\hline White Tailed Deer & Odocoileus virginianus, Muscle & $7.00 \mathrm{E}-01$ & 369 & & & Cs-137 & muscle (wet)/Rumen contents (dry) & Rabon 1968 \\
\hline White Tailed Deer & Odocoileus virginianus, Muscle & $2.27 \mathrm{E}+00$ & & & & Cs-137 & muscle (dry)/Rumen contents (dry) & Brisbin and Smith 1975 \\
\hline White Tailed Deer & Odocoileus virginianus, Muscle & $2.32 E+00$ & 562 & & & Cs-137 & muscle (dry)/Rumen contents (dry) & Haselow 1991 \\
\hline
\end{tabular}




\begin{tabular}{|c|c|c|c|c|c|c|c|c|}
\hline & & & & Location & & & & \\
\hline Medium & Organism & $\overline{\mathrm{BCF}}$ & $\overline{\mathbf{N}}$ & General & Specific & Radionuclide & Conditions & Reference \\
\hline Whice Tailed Deer & Odocoileus virginianus, Muscle & $2.20 \mathrm{E}-01$ & 562 & & & Cs-137 & muscle (wet)/Feces (dry) & Haselow 1991 \\
\hline White Tailed Deer & Odocoileus virginianus, Muscle & $1.14 \mathrm{E}+00$ & 562 & & & Cs-137 & muscle (dry)/Feces (dry) & Haselow 1991 \\
\hline White Tailed Deer & Odocoileus virginianus, Muscle & $4.80 \mathrm{E}+00$ & & & & Cs-137 & muscle (wet)/diet & Jenkins and Findley $1971 \mathrm{a}$ \\
\hline White Tailed Deer & Odocoileus virginianus & $1.32 \mathrm{E}+00$ & & & & Cs-137 & whole body/rumen & Brisbin and Smith 1975 \\
\hline White Tailed Deer & Odocoileus virginianus & $5.10 \mathrm{E}-01$ & 571 & & & Cs-137 & rumen contents (dry)/rumen contents (dry) & Haselow 1991 \\
\hline Willow & Salix nigra, leaves & $3.80 \mathrm{E}+00$ & 24 & Steel Creek & Floodplain & Cs-137 & field experiment & Garten et. al. 1975a \\
\hline Willow & Salix nigra, roots & $6.20 \mathrm{E}+00$ & 24 & Steel Creek & Floodplain & Cs-137 & field experiment & Garten et. al. 1975a \\
\hline Willow & Salix nigra, species mean & $3.80 \mathrm{E}+00$ & 24 & Steel Creek & Floodplain & Cs-137 & field experiment & Garten et. al. 1975a \\
\hline Willow & Salix nigra, stems & $1.30 \mathrm{E}+00$ & 24 & Steel Creek & Floodplain & $\mathrm{Cs}-137$ & field experiment & Garten et. al. 1975a \\
\hline Bahia Grass & Paspalum notatum & $4.00 \mathrm{E}-04$ & 7 & HArea & Field I & Pu-238 & sand $=70 \%$, silt $=7 \%$, clay $=23 \%$, greenhouse & McLeod et. al. 1981 \\
\hline Bahia Grass & Paspalum notatum & $5.60 \mathrm{E}-03$ & 7 & H Area & Field 2 & Pu-238 & sand $=77 \%$, silt $=8 \%$, clay $=16 \%$, greenhouse & MeLeod et. al. 1981 \\
\hline Bahia Grass & Paspalum notatum & $6.60 \mathrm{E}-05$ & 7 & HArea/FMB & Floodplain & $\mathrm{Pu}-238$ & sand $=69 \%$, silt $=11 \%$, clay $=20 \%$, greenhouse & McLeod et. al. 1981 \\
\hline Bahia Grass & Paspalum notatum & $6.00 \mathrm{E}-05$ & 7 & H Area/FMB & Floodplain & $\mathrm{Pu}-238$ & sand $=69 \%$, clay $=20 \%$, greenhouse, lst year & Adriano et. al. 1986 \\
\hline Bahia Grass & Paspalum notatum & $1.90 \mathrm{E}-04$ & 7 & HArea/FMB & Floodplain & Pu-238 & sand $=69 \%$, clay $=20 \%$, greenhouse, 4 th year & Adriano et. al. 1986 \\
\hline Clover & Trifolium repens & $6.10 \mathrm{E}-04$ & 7 & HArea & Field 1 & $\mathrm{Pu}-238$ & sand $=70 \%$, silt $=7 \%$, clay $=23 \%$, greenhouse & McLeod et. al. 1981 \\
\hline Clover & Trifolium repens & $6.70 \mathrm{E}-02$ & 7 & H Area & Field 2 & $\mathrm{Pu}-238$ & sand $=77 \%$, silt $=8 \%$, clay $=16 \%$, greenhouse & McLeod et. al. 1981 \\
\hline Clover & Trifolium repens & $4.20 \mathrm{E}-04$ & 7 & H Area/FMB & Floodplain & Pu-238 & sand $=69 \%$, silt $=11 \%$, clay $=20 \%$, greenhouse & McLeod et. al. 1981 \\
\hline Clover & Trifolium repens & $4.10 \mathrm{E}-04$ & 7 & H Area/FMB & Floodplain & $\mathrm{Pu}-238$ & sand $=69 \%$, clay $=20 \%$, greenhouse, 1 st year & Adriano et. al. 1986 \\
\hline Clover & Trifolium repens & $1.47 \mathrm{E}-04$ & 7 & HArea/FMB & Floodplain & Pu-238 & sand $=69 \%$, clay $=20 \%$, greenhouse, 4 th year & Adriano et. al. 1986 \\
\hline Corn & Zea mays, Leaves & $1.70 \mathrm{E}-04$ & 7 & H Area/FMB & Floodplain & Pu-238 & sand $=69 \%$, clay $=20 \%$, greenhouse, 1 st year & Adriano et. al. 1986 \\
\hline$\overline{C o r n}$ & Zea mays, Leaves & $3.40 \mathrm{E}-04$ & 7 & HArea/FMB & Floodplain & $\mathrm{Pu}-238$ & sand $=69 \%$, clay $=20 \%$, greenhouse, 4 th year & Adriano et. al. 1986 \\
\hline Corn & Zea mays, Leaves & $7.50 \mathrm{E}-04$ & 7 & H Area & Field 1 & Py-238 & sand $=70 \%$, silt $=7 \%$, clay $=23 \%$, greenhouse & McLeod et. al. 1981 \\
\hline Corn & Zea mays, Leaves & $1.90 \mathrm{E}-02$ & 7 & HArea & Field 2 & $\mathrm{Pu}-238$ & sand $=77 \%$, silt $=8 \%$, clay $=16 \%$, greenhouse & McLeod et. al. 1981 \\
\hline Corn & Zea mays, Leaves & $1.80 \mathrm{E}-04$ & 7 & H Area/FMB & Floodplain & Pu-238 & sand $=69 \%$, silt $=11 \%$, clay $=20 \%$, greenhouse & McLeod et. al. 1981 \\
\hline Corn & Zea mays, Stalk & $6.80 \mathrm{E}-04$ & 7 & H Area & Field I & Pu-238 & sand $=70 \%$, silt $=7 \%$, clay $=23 \%$, greenhouse & McLeod et. al. 1981 \\
\hline$\overline{\operatorname{Cos} n}$ & Zea mays, Stalk & $3.60 \mathrm{E}-02$ & 7 & H Area & Field 2 & Pu-238 & sand $=77 \%$, silt $=8 \%$, clay $=16 \%$, greenhouse & McLeod et. al. 1981 \\
\hline Corn & Zea mays, Stalk & $2.10 \mathrm{E}-04$ & 7 & HArea/FMB & Floodplain & Pu-238 & sand $\approx 69 \%$, silt $=11 \%$, clay $=20 \%$, greenhouse & McLeod et. al. 1981 \\
\hline Corn & Zea mays, standing vegetation & $4.50 \mathrm{E}-01$ & 10 & NE SRS & & Pu-238 & sand $=66 \%$, silt $=6 \%$, clay $=28 \%$, greenhouse, after 30 days & Hersloff and Corey 1978 \\
\hline Corn & Zea mays, standing vegetation & $1.50 \mathrm{E}-01$ & 10 & NE SRS & & Pu-238 & sand $=66 \%$, silt $=6 \%$, clay $=28 \%$, greenhouse, after 50 days & Hersloff and Corey 1978 \\
\hline
\end{tabular}




\begin{tabular}{|c|c|c|c|c|c|c|c|c|}
\hline & & & & Locatior & & & & \\
\hline Medium & Organism & BCF & $\overline{\mathbf{N}}$ & General & Specific & \begin{tabular}{|l} 
Radionuclide \\
\end{tabular} & Conditions & Reference \\
\hline Pine Tree & Leaves & $4.70 \mathrm{E}-03$ & 12 & SRL & $\longdiv { \text { Basin } 4 }$ & Pu-238 & & Murphy 1992 \\
\hline Pine Tree & Leaves & $1.50 \mathrm{E}-04$ & 16 & SRL & Basin Edge & Pu-238 & & Murphy 1992 \\
\hline Rice & Belle Patna, foliage & $3.10 \mathrm{E}-04$ & 6 & HArea/FMB & Floodplain & Pu-238 & silt $=11 \%$, clay $=20 \%$, greenhouse & Adriano et. al. 1981a \\
\hline Rice & Belle Patna, Grain & $9.00 \mathrm{E}-05$ & 6 & HArea/ FMB & Floodplain & Pu-238 & silt $=11 \%$, clay $=20 \%$, greenhouse & Adriano et. al. 1981a \\
\hline Rice & IR-1561, foliage & $2.60 \mathrm{E}-04$ & 6 & HArea/FMB & Floodplain & $\mathrm{Pu}-238$ & silt $=11 \%$, clay $=20 \%$, greenhouse & Adriano et. al. 1981a \\
\hline Rice & IR-1561, Grain & $3.60 \mathrm{E}-04$ & 6 & HArea/ FMB & Floodplain & $\mathrm{Pu}-238$ & silt $=11 \%$, clay $=20 \%$, greenhouse & Adriano et. al. 1981a \\
\hline Rice & Nato, foliage & $4.90 \mathrm{E}-04$ & 6 & H Area/ FMB & Floodplain & $P u-238$ & silk $=11 \%$, clay $=20 \%$, greenhouse & Adriano et. al. 1981a \\
\hline Rice & Nato, Grain & $2.60 \mathrm{E}-04$ & 6 & H Area/FMB & Floodplain & $\mathrm{Pu}-238$ & silt $=11 \%$, clay $=20 \%$, greenhouse & Adriano et. al. $1981 \mathrm{a}$ \\
\hline Rice & Starbonnet, foliage & $2.60 \mathrm{E}-04$ & 6 & HArea/FMB & Floodplain & Pu-238 & silt $=11 \%$, clay $=20 \%$, greenhouse & Adriano et. al. 1981a \\
\hline Rice & Starbonnet, Grain & $1.40 \mathrm{E}-04$ & 6 & HArea/FMB & Floodplain & $\mathrm{Pu}-238$ & silt $=11 \%$, clay $=20 \%$, greenhouse & Adriano et. al. 1981a \\
\hline Soybean & Glycine max, Bean & $2.40 E-03$ & 7 & H Area & Field 1 & Pu-238 & sand $=70 \%$, silt $=7 \%$, clay $=23 \%$, greenhouse & McLeod et. al. 1981 \\
\hline Soybean & Glycine max, Bean & $2.60 \mathrm{E}-01$ & 7 & H Area & Field 2 & $\mathrm{Pu}-238$ & sand $=77 \%$, silt $=8 \%$, clay $=16 \%$, greenhouse & McLeod et. al. 1981 \\
\hline Soybean & Glycine max, Bean & $5.20 \mathrm{E}-04$ & 7 & HAreal FMB & Floodplain & $\mathrm{Pu}-238$ & sand $=69 \%$, silt $=11 \%$, clay $=20 \%$, greenhouse & McLeod et. al. 1981 \\
\hline Soybean & Glycine max, Stem & $8.30 \mathrm{E}-04$ & 7 & H Area/ FMB & Floodplain & $\mathrm{Pu}-238$ & sand $=69 \%$, clay $=20 \%$, greenhouse, ist year & Adriano et. al. 1986 \\
\hline Soybean & Glycine max, Stem & $1.06 \mathrm{E}-03$ & 7 & HArea/ FMB & Floodplain & Pu-238 & sand $=69 \%$, clay $=20 \%$, greenhouse, 4 th year & Adriano et. al. 1986 \\
\hline Soybean & Glycine max, Stem & $3.00 \mathrm{E}-03$ & 7 & HArea & Field 1 & $\mathrm{Pu}-238$ & sand $=70 \%$, silt $=7 \%$, clay $=23 \%$, greenhouse & McLeod et. al. 1981 \\
\hline Soybean & Glycine max, Stem & $1.60 \mathrm{E}-01$ & 7 & HArea & Field 2 & Pu-238 & sand $=77 \%$, silt $=8 \%$, clay $=16 \%$, greenhouse & McLeod et. al. 1981 \\
\hline Soybean & Glycine max, Stem & $6.80 \mathrm{E}-04$ & 7 & HArea/ FMB & Floodplain & $\mathrm{Pu}-238$ & sand $=69 \%$, silt $=11 \%$, clay $=20 \%$, greenhouse & McLeod et. al. 1981 \\
\hline Tree & Maple, sweetgum, and poplar, Bark & $2.70 \mathrm{E}-04$ & 9 & HArea/FMB & Floodplain & Pu-238 & Field experiment, corrected for uptake only & Pinder et. al. 1984 \\
\hline Tree & Maple, sweetgum, and poplar, Leaves & $3.00 \mathrm{E}-04$ & 9 & HArea/ FMB & Floodplain & $\mathrm{Pu}-238$ & Field experiment, corrected for uptake only & Pinder et. al. 1984 \\
\hline Tree & Maple, sweetgum, and poplar, Wood & $3.30 \mathrm{E}-05$ & 9 & HArea/ FMB & Floodplain & Pu-238 & Field experiment, corrected for uptake only & Pinder et. al. 1984 \\
\hline Wheat & Triticum aestivum, Grain & $1.80 \mathrm{E}-03$ & 7 & H Area & Field 1 & $\mathrm{Pu}-238$ & sand $=70 \%$, silt $=7 \%$, clay $=23 \%$, greenhouse & McLeod et. al. 1981 \\
\hline Wheat & Triticum aestivum, Grain & $3.50 \mathrm{E}-02$ & 7 & HArea & Field 2 & Pu-238 & sand $=77 \%$, silt $=8 \%$, clay $=16 \%$, greenhouse & McLeod et. al. 1981 \\
\hline Wheat & Triticum aestivum, Grain & 3.70E-04 & 7 & HArea/FMB & Floodplain & Pu-238 & sand $=69 \%$, silt $=11 \%$, clay $=20 \%$, greenhouse & McLeod et. al. 1981 \\
\hline Wheat & Triticum aestivum, Stem & $2.40 \mathrm{E}-04$ & 7 & H Area/FMB & Floodplain & $\mathrm{Pu}-238$ & sand $=69 \%$, clay $=20 \%$, greenhouse, Ist year & Adriano et. al. 1986 \\
\hline Wheat & Triticum aestivum, Stem & $1.04 \mathrm{E}-03$ & 7 & H Area/FMB & Floodplain & Pu-238 & sand $=69 \%$, clay $=20 \%$, greenhouse, 4 th year & Adriano et. al. 1986 \\
\hline Wheat & Triticum aestivum, Vegetation & $6.80 \mathrm{E}-04$ & 7 & H Area & Field 1 & Pu-238 & sand $=70 \%$, silt $=7 \%$, clay $=23 \%$, greenhouse & McLeod et. al. 1981 \\
\hline Wheat & Triticum aestivum, Vegetation & $1.40 \mathrm{E}-02$ & 7 & HArea & Field 2 & Pu-238 & sand $=77 \%$, silt $=8 \%$, clay $=16 \%$, greenhouse & McLeod et. al. 1981 \\
\hline Wheat & Triticum aestivum, Vegetation & $2.50 \mathrm{E} \cdot 04$ & 7 & HArea/FMB & Floodplain & $\mathrm{Pu}-238$ & sand $=69 \%$, silt $=11 \%$, clay $=20 \%$, greenhouse & McLeod et. al. 1981 \\
\hline Corn & Zea mays, standing vegetation & $1.70 \mathrm{E}-01$ & 10 & NE SRS & & Pu-239 & $\operatorname{sand}=66 \%$, silt $=6 \%$, clay $=28 \%$, greenhouse, after 30 days & Hersioff and Corey 1978 \\
\hline Corn & Zea mays, standing vegetation & $7.20 \mathrm{E}-02$ & 10 & NE SRS & & Pu-239 & sand $=66 \%$, silt $=6 \%$, clay $=28 \%$, greenhouse, after 50 days & Hersloff and Corey 1978 \\
\hline Bahia grass & Paspalum notatum & $8.90 \mathrm{E}-05$ & 7 & H Area & Field 1 & $\mathrm{Pu}-239,240$ & sand $=70 \%$, sil $=7 \%$, clay $=23 \%$, greenhouse & McLeod et. al. 1981 \\
\hline Bahia grass & Paspalum notatum & $2.30 \mathrm{E}-03$ & 7 & HArea & Field 2 & $\mathrm{Pu}-239,240$ & sand $=77 \%$, silt $=8 \%$, clay $=16 \%$, greenhouse & MeLeod et. al. 1981 \\
\hline Bahia grass & Paspalum notatum & $4.40 \mathrm{E}-03$ & 7 & H Area/FMB & Floodplain & $\overline{\mathrm{Pu}-239,240}$ & sand $=69 \%$, silt $=11 \%$, clay $=20 \%$, greenhouse & McLeod et. al. 1981 \\
\hline
\end{tabular}




\begin{tabular}{|c|c|c|c|c|c|c|c|c|}
\hline & & & & Location & & & & \\
\hline Medium & Organism & $\overline{\mathrm{BCF}}$ & $\bar{N}$ & General & Specific & Radionuclide & Conditions & Reference \\
\hline Clover & Trifolium repens & $1.40 \mathrm{E}-04$ & 7 & HArea & Field 1 & $\mathrm{Pu}-239,240$ & sand $=70 \%$, silt $=7 \%$, clay $=23 \%$, greenhouse & McLeod et. al. 1981 \\
\hline Clover & Trifolium repens & $1.90 \mathrm{E}-02$ & 7 & H Area & Field 2 & $\mathrm{Pu}-239,240$ & sand $=77 \%$, silt $=8 \%$, clay $=16 \%$, greenhouse & McLeod et. al. 1981 \\
\hline Clover & Trifolium repens & $2.00 \mathrm{E}-02$ & 7 & HArea/FMB & Floodplain & Pu-239,240 & sand $=69 \%$, silt $=11 \%$, clay $=20 \%$, greenhouse & McLeod et. al. 1981 \\
\hline Corn & Zea mays, Leaves & $2.10 \mathrm{E}-04$ & 7 & H Area & Field 1 & Pu-239,240 & sand $=70 \%$, silt $=7 \%$, clay $=23 \%$, greenhouse & McLeod et. al. 1981 \\
\hline Corn & Zea mays, Leaves & $6.10 \mathrm{E}-03$ & 7 & H Area & Field 2 & $\longdiv { \mathrm { Pu } - 2 3 9 , 2 4 0 }$ & sand $=77 \%$, silt $=8 \%$, clay $=16 \%$, greenhouse & McLeod et. al. 1981 \\
\hline Corn & Zea mays, Leaves & $1.40 \mathrm{E}-02$ & 7 & HArea/FMB & Floodplain & $\overline{P u-239,240}$ & sand $=69 \%$, silt $=11 \%$, clay $=20 \%$, greenhouse & McLeod et. al. 1981 \\
\hline Corn & Zea mays, Stalk & $1.60 \mathrm{E}-04$ & 7 & H Area & Field I & $\mathrm{Pu}-239,240$ & sand $=70 \%$, silt $=7 \%$, clay $=23 \%$, greenhouse & McLeod et. al. 1981 \\
\hline Corn & Zea mays, Stalk & $1.00 \mathrm{E}-02$ & 7 & HArea & Field 2 & Pu-239,240 & sand $=77 \%$, silt $=8 \%$, clay $=16 \%$, greenhouse & McLeod et. al. 1981 \\
\hline Corn & Zea mays, Stalk & $1.70 \mathrm{E}-02$ & 7 & H Area/FMB & Floodplain & Pu-239,240 & sand $=69 \%$, silt $=11 \%$, clay $=20 \%$, greenhouse & McLeod et. al. 1981 \\
\hline Pine Tree & Leaves & $7.30 \mathrm{E}-03$ & 12 & SRL & Basin 4 & Pu-239,240 & & Murphy 1992 \\
\hline Pine Tree & Leaves & $1.20 \mathrm{E}-04$ & 16 & SRL & Basin Edge & Pu-239,240 & & Murphy 1992 \\
\hline Rice & Belle Patna, foliage & $7.50 \mathrm{E}-03$ & 6 & H Area/FMB & Floodplain & $\mathrm{Pu}-239,240$ & silt $=11 \%$, clay $=20 \%$, greenhouse & Adriano et. al. 1981a \\
\hline Rice & Belle Patna, Grain & $7.90 \mathrm{E}-03$ & 6 & HArea/FMB & Floodplain & $\mathrm{Pu}-239,240$ & silt $=11 \%$, clay $=20 \%$, greenhouse & Adriano et. al. $1981 \mathrm{a}$ \\
\hline Rice & IR-1561, foliage & $2.50 \mathrm{E}-02$ & 6 & H Area/FMB & Floodplain & $\mathrm{Pu}-239,240$ & sitt $=11 \%$, clay $=20 \%$, greenhouse & Adriano et. al. 198la \\
\hline Rice & IR-1561, Grain & $1.50 \mathrm{E}-02$ & 6 & H Area/FMB & Floodplain & $\overline{P u-239,240}$ & silt $=11 \%$, clay $=20 \%$, greenhouse & Adriano et. al. 1981a \\
\hline Soybean & Glycine max, Bean & $5.60 \mathrm{E}-04$ & 7 & H Area & Field I & Pu-239,240 & sand $=70 \%$, silt $=7 \%$, clay $=23 \%$, greenhouse & McLeod et. al. 1981 \\
\hline Soybean & Glycine max, Bean & $7.40 \mathrm{E}-02$ & 7 & H Area & Field 2 & $\mathrm{Pu}-239,240$ & sand $=77 \%$, silt $=8 \%$, clay $=16 \%$, greenhouse & McLeod et. al. 1981 \\
\hline Soybean & Glycine max, Bean & $3.90 \mathrm{E}-02$ & 7 & HArea/FMB & Floodplain & Pu-239,240 & sand $=69 \%$, silt $=11 \%$, clay $=20 \%$, greenhouse & McLeod et. al. 1981 \\
\hline Soybean & Glycine max, Stem & $7.20 \mathrm{E}-04$ & 7 & H Area & Field 1 & $\mathrm{Pu}-239,240$ & sand $=70 \%$, silt $=7 \%$, clay $=23 \%$, greenhouse & McLead et. al. 1981 \\
\hline Soybean & Glycine max, Stem & $4.70 \mathrm{E}-02$ & 7 & H Area & Field 2 & $\mathrm{Pu}-239,240$ & sand $=77 \%$, silt $=8 \%$, clay $=16 \%$, greenhouse & McLeod et. al. 1981 \\
\hline Soybean & Glycine max, Stem & $5.40 \mathrm{E}-02$ & 7 & H Area/FMB & Floodplain & $\mathrm{Pu}-239,240$ & $\operatorname{sand}=69 \%$, silt $=11 \%$, clay $=20 \%$, greenhouse & McLeod et. al. 1981 \\
\hline Wheat & Triticum aestivum, Grain & $4.20 \mathrm{E}-04$ & 7 & H Area & Field I & $\mathrm{Pu}-239,240$ & sand $=70 \%$, silt $=7 \%$, clay $=23 \%$, greenhouse & McLeod et. al. 1981 \\
\hline Wheat & Triticum aestivum, Grain & $1.00 \mathrm{E}-02$ & 7 & HArea & Field 2 & Pu-239,240 & sand $=77 \%$, silt $=8 \%$, clay $=16 \%$, greenhouse & McLeod et. al. 1981 \\
\hline Wheat & Triticum aestivum, Grain & $2.90 \mathrm{E}-02$ & 7 & H Area/FMB & Floodplain & Pu-239,240 & sand $=69 \%$, silt $=11 \%$, clay $=20 \%$, greenhouse & McLeod et. al. 1981 \\
\hline Wheat & Triticum aestivum, Vegetation & $1.80 \mathrm{E}-04$ & 7 & H Area & Field 1 & $\mathrm{Pu}-239,240$ & sand $=70 \%$, silt $=7 \%$, clay $=23 \%$, greenhouse & McLeod et. al. 1981 \\
\hline Wheat & Triticum aestivum, Vegetation & $4.10 \mathrm{E}-03$ & 7 & H Area & Field 2 & $\mathrm{P} u-239,240$ & sand $=77 \%$, silt $=8 \%$, clay $=16 \%$, greenhouse & McLeod et. al. 1981 \\
\hline Wheat & Triticum aestivum, Vegetation & $1.30 \mathrm{E}-02$ & 7 & H Area/FMB & Floodplain & $\mathrm{Pu}-239,240$ & sand $=69 \%$, silt $=11 \%$, clay $=20 \%$, greenhouse & McLeod et. al. 1981 \\
\hline Rice & Belle Patna, foliage & $4.00 \mathrm{E}-01$ & 6 & H Area/FMB & Floodplain & $\mathrm{Ra}-226$ & silt $=11 \%$, clay $=20 \%$, greenhouse & Adriano et. al. 1981a \\
\hline Rice & Belle Patna, Grain & $6.90 \mathrm{E}-01$ & 6 & H Area/ FMB & Floodplain & $\mathrm{Ra}-226$ & silt $=11 \%$, clay $=20 \%$, greenhouse & Adriano et. al. 1981a \\
\hline Rice & IR-1561, foliage : & $1.80 \mathrm{E}+00$ & 6 & HArea/FMB & Floodplain & $\mathrm{Ra}-226$ & silt $=11 \%$, clay $=20 \%$, greenhouse & Adriano et. al. 1981a \\
\hline Rice & IR-1561, Grain & $1.03 \mathrm{E}+00$ & 6 & H Area/ FMB & Floodplain & $\overline{R a-226}$ & silt $=11 \%$, clay $=20 \%$, greenhouse & Adriano et. al. 1981a \\
\hline Tree & Maple, sweetgum, and poplar, Bark & $7.00 \mathrm{E}-01$ & 9 & H Area/FMB & Floodplain & $\overline{R a-226}$ & Field experiment & Pinder et. al. 1984 \\
\hline Tree & Maple, sweetgum, and poplar, Leaves & $2.00 \mathrm{E}+00$ & 9 & H Area/FMB & Floodplain & $\mathrm{Ra}-226$ & Field experiment & Pinder et. al. 1984 \\
\hline Tree & Maple, sweetgum, and poplar, Wood & $1.00 \mathrm{E}-02$ & 9 & HArea/FMB & Floodplain & $\overline{R a-226}$ & Field experiment & Pinder et. al. 1984 \\
\hline
\end{tabular}




\begin{tabular}{|c|c|c|c|c|c|c|c|c|}
\hline & & & & Location & & & & \\
\hline Medium & $\overline{\text { Organism }}$ & $\overline{\mathrm{BCF}}$ & $\mathbf{N}$ & General & Specific & Radionuclide & Conditions & $\begin{array}{l}\text { Reference } \\
\end{array}$ \\
\hline Corn & Zea mays, Grain & $1.50 \mathrm{E}-01$ & $\overline{13}$ & Burial Grnd & & $\overline{\mathrm{Sr}-90}$ & Roots did not penetrate waste & Gay 1982 \\
\hline Corn & Zea mays, Leaves & $1.31 \mathrm{E}+01$ & $\sqrt{13}$ & Burial Gind & & Sr-90 & Roots did not penetrate waste & Gay 1982 \\
\hline Pine Tree & Leaves & $1.69 \mathrm{E}+00$ & $\sqrt{12}$ & SRL & $\overline{\text { Basin } 4}$ & $\begin{array}{l}\mathrm{Sr}-90 \\
\end{array}$ & & Murphy 1992 \\
\hline Pine Tree & Leaves & $8.80 \mathrm{E}-01$ & 16 & SRL & \begin{tabular}{l|l} 
Basin Edge \\
\end{tabular} & $\overline{\mathrm{Sr}-90}$ & & Murphy 1992 \\
\hline Soybeans & $\begin{array}{l}\text { Glycine max, } \\
\text {. }\end{array}$ & $2.51 \mathrm{E}+00$ & 10 & Burial Grou & & Sr -90 & Roots did not penetrate waste & Gay 1982 \\
\hline Tree & Maple, sweetgum, and poplar, Bark & $1.10 \mathrm{E}+01$ & 9 & HArea/FMB & Floodplain & Sr-90 & Field experiment & Pinder et. al. 1984 \\
\hline Tree & Maple, sweetgum, and poplar, Leaves & $3.80 \mathrm{E}+00$ & $\overline{9}$ & H Area/FMB & Floodplain & Sr-90 & Field experiment & Pinder et. al. 1984 \\
\hline Tree & Maple, sweetgum, and poplar, Wood & $8.10 \mathrm{E}-01$ & 9 & H Area/ FMB & Floodplain & Sr-90 & Field experiment & Pinder et. al. 1984 \\
\hline Corn & Zea mays, Grain & $6.00 \mathrm{E}-05$ & 6 & HArea & South Field & Total Pu & Vaucluse soil, $\mathrm{pH}=4.6$, greenhouse & Adriano et. al. $1980 \mathrm{a}$ \\
\hline Corn & Zea mays, Leaves & $6.00 \mathrm{E}-04$ & 6 & HArea & South Field & Total Pu & Vaucluse soil, $\mathrm{pH}=4.6$, greenhouse & Adriano et. al. 1980a \\
\hline Soybeans & Glycine max, Whole plant & $3.00 \mathrm{E}-03$ & 10 & H Area & South Field | & Total Pu & Vaucluse soil, $\mathrm{pH}=4.6$, greenhouse & Adriano et. al. 1980a \\
\hline Wheat & Triticum aestivum, Straw & $2.00 \mathrm{E}-03$ & 10 & H Area & South Field & Total Pu & Vaucluse soil, $\mathrm{pH}=4.6$, greenhouse & Adriano et. al. 1980a \\
\hline White Tailed Deer & Odocoileus virginianus, Bone & $1.50 \mathrm{E}-02$ & 3 & HArea & & Total Pu & Dry weight, Animal/Soil & Kirkam et. al. 1979 \\
\hline White Tailed Deer & Odocolleus virginianus, Bone & $1.75 \mathrm{E}-01$ & 3 & H Area & & Total Pu & Dry weight, Animal/Vegetation (honeysuckle) & Kirkam et. al. 1979 \\
\hline White Tailed Deer & Odocoileus virginianus, Liver & $1.30 \mathrm{E}-02$ & 3 & H Area & & $\overline{\text { Total Pu }}$ & Dry weight, Animal/Soil & Kirkam et. al. 1979 \\
\hline White Tailed Deer & Odocoileus virginianus, Liver & $1.48 \mathrm{E}-01$ & 3 & H Area & & Total Pu & Dry weight, Animal/vegetation (honeysuckle) & Kirkam et. al. 1979 \\
\hline White Tailed Deer & Odocoileus virginianus, Lungs & $6.00 \mathrm{E}-03$ & 3 & HArea & & Total Pu & Dry weight, Animal/Soil & Kirkam et. al. 1979 \\
\hline White Tailed Deer & Odocoileus virginianus, Lungs & $7.30 \mathrm{E}-02$ & 3 & HArea & & $\overline{\text { Total Pu }}$ & Dry weight, Animal/Vegetation (honeysuckle) & Kirkam et. al. 1979 \\
\hline White Tailed Deer & Odocoileus virginianus, Muscle & $1.00 \mathrm{E}-03$ & 3 & $\overline{\text { H Area }}$ & & Total Pu & Dry weight, Animal/Soil & Kirkam et. al. 1979 \\
\hline White Tailed Deer & Odocoil & $1.40 \mathrm{E}-03$ & 3 & HArea & & Total Pu & Dry weight, Animal/Vegetation (honeysuckle) & Kirkam et. al. 1979 \\
\hline
\end{tabular}




\section{APPENDIX C}

MAP OF SAVANNAH RIVER SITE 
C-2 


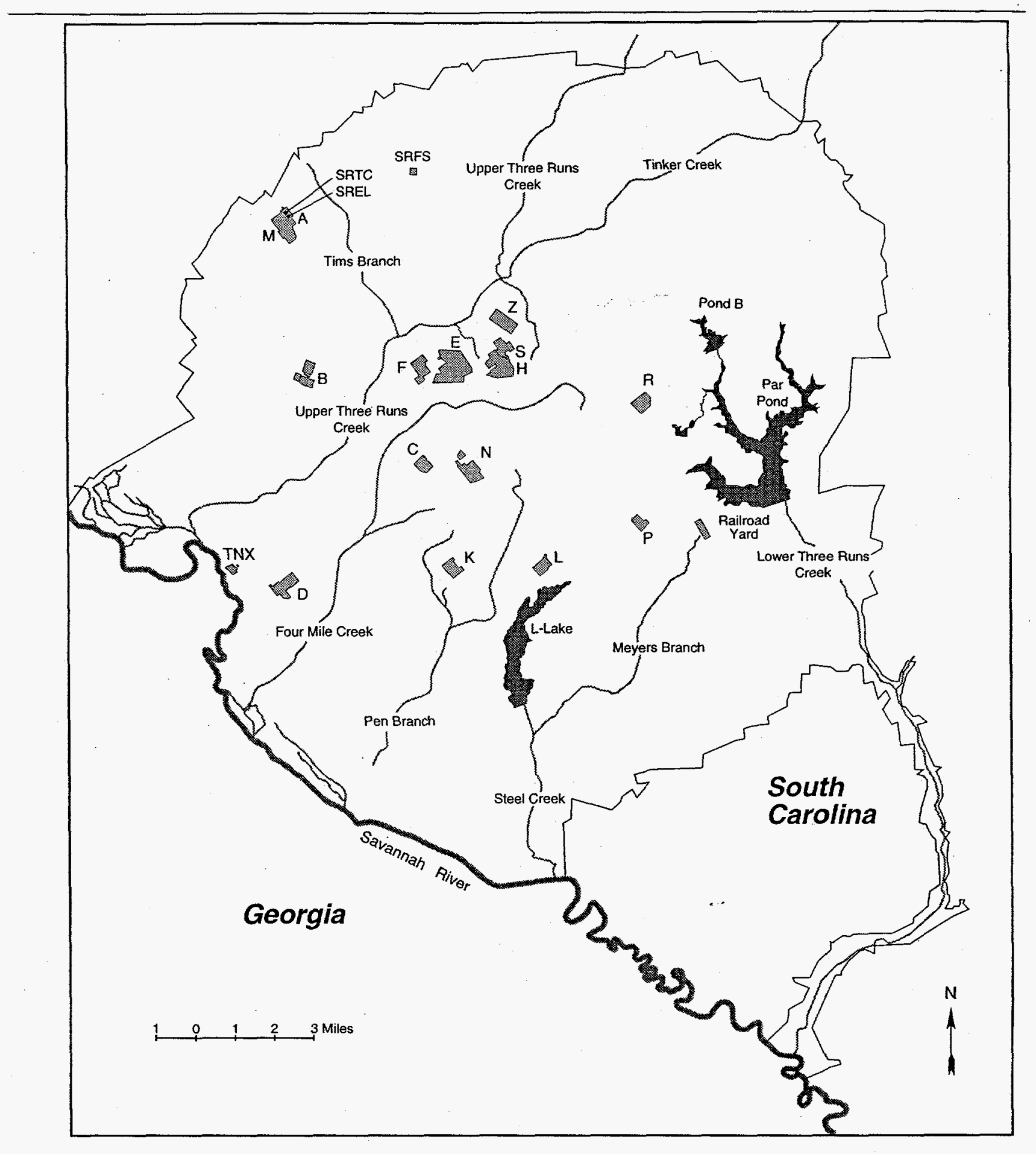

FIGURE 1. SAVANNAH RIVER SITE 